
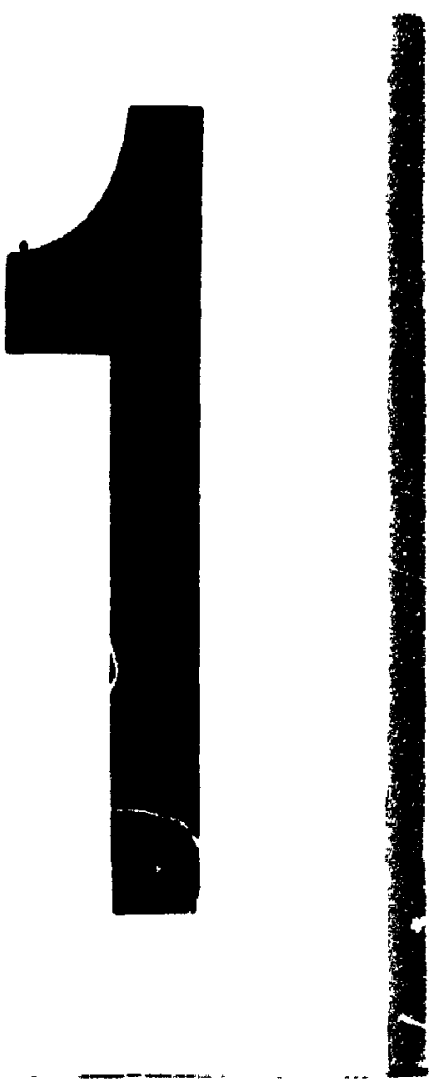

PM-1 31/2"X4" PHOTOGRAPHIC MICROCOPY TA.AGET NBS 1010a ANSI/ISO 22 EQUIVALENT

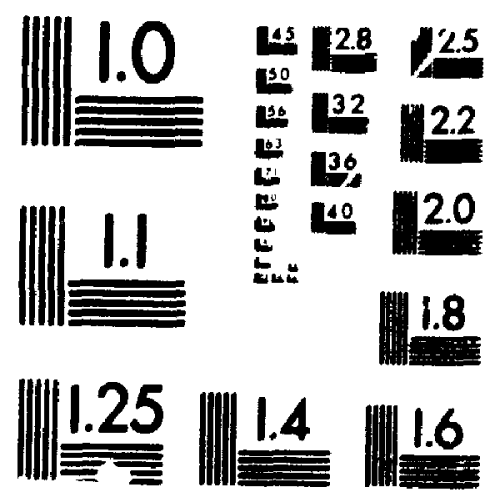

PRECISIONEN RESOLUTION TARGEIS

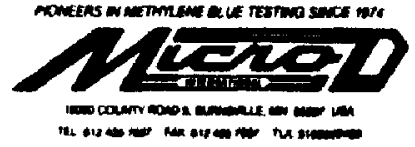


The quality of this microform is heavily dependent upon the quality of the original thesis submitted for microfilming. Every effort has been made to ensure the highest quality of reproduction possible.

If pages are missing, contact the university which granted the degree.

Some pages may have indistinct print especially if the original pages were typed with a poor typewriter ribbon or if the university sent us an inferior photocopy.

Reproduction in full or in part of this microform is governed by the Canadian Copyright Act, R.S.C. 1970, c. C-30, and subsequent amendments.
La qualité de cette microforme dépend grandement de la qualité de la thèse soumise au microfilmage. Nous avons tout fait pour assurer une qualité supérieure de reproduction.

S'il manque dies pages, veuillez communiquer avec l'université qui a conféré le grade.

La qualité d'impression de certaines pages peut laisser à désirer, surtout si les pages originales ont été dactylographiées à l'aide d'un ruban usé ou si l'université nous a fait parvenir une photocopie de qualité inférieure.

La reproduction, même partielle, de cette microforme est soumise à la Loi canadienne sur le droit d'auteur, SRC 1970, c. C-30, et ses amendements subséquents. 


\title{
THE MOLECULAR BIOLOGY OF METHANOGENS: CELL LYSIS, PLASMID SURVEY AND THE
}

\section{CHARACTERIZATION OF A NOVEL PLASMID}

by

STEPHANIE ASALYN MEAKIN

\author{
A thesis submitted to \\ the faculty of Graduate Studies and Research \\ in partial fulfilment of \\ the requirements for the degree of \\ Master of Science (Biology) \\ Department of Biology \\ Carleton University \\ Ottawa, Ontario \\ May, 1992 \\ copyright
}

1992, Stephanie A. Meakin 
The author has granted an irrevocable non-exclusive licence allowing the National Library of Canada to reproduce, Ioan, distribute or sell copies of his/her thesis by any means and in any form or format, making this thesis available to interested persons.
L'auteur a accordé une licence irrévocable et non exclusive permettant à la Bibliothèque nationale du Canada de reproduire, prêter, distribuer ou vendre des copies de sa these de quelque manière et sous quelque forme que ce soit pour mettre des exemplaires de cette thèse à la disposition des personnes intéressées.

L'auteur conserve la propriété du droit d'auteur qui protège sa thèse. Ni la thèse ni des extraits substantiels de celle-ci ne doivent être imprimés ou autrement reproduits sans son autorisation. 


\section{Carleton University}

Ottawa, Canada K1S5B6

Theais contains black \& white photographs a/or explanatory tables which when microfilmed may loge their Bignificance. The hardcopy of the thesis is available upon request from Carleton University Library. 
The undersigned hereby recommend to

the faculity of Graduate Studies and Research

acceptance of this thesis,

\section{THE MOLECULAR BIOLOGY OF METHANOGENS:CELL}

LYSIS, PLASMID SURVEY AND THE

\section{CHARACTERIzation OF A NOVEL PLASMID}

submitted by

Stephanie A. Meakin, B.A. (Honours) Biology

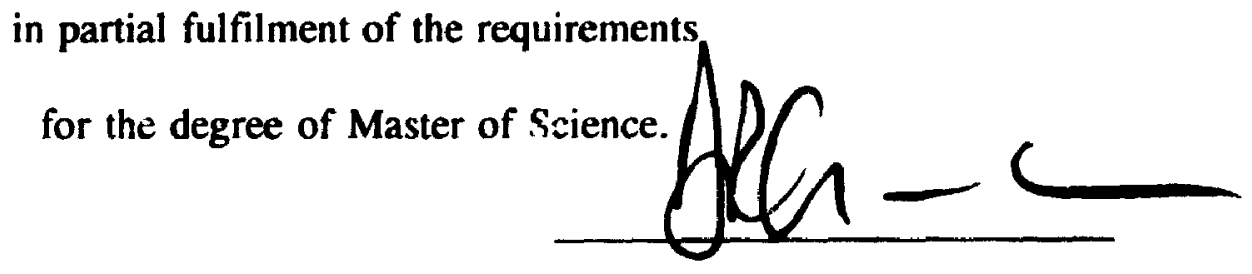

Chair, Department of Biology

D. Gardner, Ph.D.

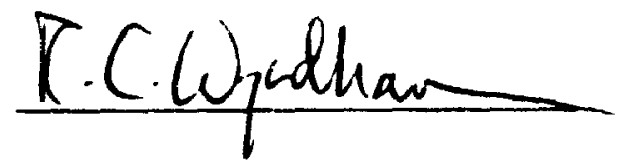

Thesis Supervisors

Campbell Wyndham, Ph.D.

G. Denis Sprott, Ph.D.

Carleton University

June 8, 1992 


\begin{abstract}
Methanogens form a diverse group of organisms, of interest because of their physiology, morphology and taxonomy. They play an essential role in the environment in the global recycling of methane and are responsible for anaerobic degradation of natural as well as xenobiotic compounds. This thesis outlines the taxonomy, biochemistry and molecular biology of this group of organisms and presents a generally applicable method of lysis for methanogens, the screening of a number of species for plasmids and the characterization of a novel plasmid pDDK from Methanosaeata concilli GP6. pDDK was found to be a circular molecu,e with a molecular weight of $11.0 \mathrm{~kb}$, 10 copies per cell, a restriction map is also presented. This type of work is important in the development of genetic tools which may unravel many of the questions that have arisen from previous investigations and as well may lead to the use of these organisms in the field of genetic engineering.
\end{abstract}




\section{ACKNOWLEDGEMENTS}

There are many people who made this thesis possible, some gave invaluable financial, scientific and technical assistance while others maintained and assisted my soul. I would like to take this opportunity to thank these people. First. Dr. Kevin kennedy who allowed me to use time at work to pursue this degree and without such a situation this would not have been possible for me. My committee: Dr. Dennis Sprott my cosupervisor, who always made time, often walking me through a section or problem. My co-supervisor Dr. Campbell Wyndham who took a chance on me and Dr. V.N. lyer, three respected scientists in their fields and all, helpful, fair professionals. Dr. John Nash who gave expert advise and scientific assistance and taught me much of what I know about molecular biology. Dr. William Murray a good friend and a respected scientist, my role model. The National Research Council where this research was carried out. Kathleen Shaw who maintained many of the cultures used (and me) and Dr. Girish Patel who supplied GP6 and much advise and support. On the emotional front Brad Methven, Brian Agnew, Christian Choquet, Margaret Anne Gidney and the coffee table gang and all my friends whom I'm sure are tired of 'sounds great but I'm working this weekend'. A group of people I have left until last because without them nothing in my life would be possible, my family. This thesis is dedicated to them, my husband David D. Kerr whom the plasmid pDDK is named after, my mom and dad Asalyn and Donald Meakin and my brother Christopher Meakin. 


\section{TABLE OF CONTENTS}

TITLE PAGE

ACCEPTANCE SHEET

ABSTRACT

ACKNOWLEDGEMENTS iv

TABLE OF CONTENTS v v

LIST OF TABLES vi

LIST OF FIGURES vii

LIST OF PHOTOGRAPHIC PLATES viii

TABLE OF ABBREVIATIONS ix

\section{SECTION I}

\section{LITERATURE REVIEW}

1.1 ARCHAEOBACTERIA 1

1.2 METHANOGENIC ARCHAEOBACTERIA 6

$\begin{array}{lll}1.3 & \text { TAXONOMY } & 7\end{array}$

1.4 DIVERSITY OF METHANOGENS 9

$\begin{array}{llr}1.5 & \text { METHANOBACTERIALES } & 12\end{array}$

$\begin{array}{lll}1.6 & \text { METHANOCOCCALES } & 14\end{array}$

1.7 METHANOMICROBIALES 14

1.8 ENERGY METABOLISM-METHANOGENESIS 17

$\begin{array}{ll}1.9 \text { UNIQUE COFACTORS } & 19\end{array}$ 
1.10 METHANOGENIC PATHWAYS 21

$\begin{array}{ll}1.11 \text { CELL WALL STRUCTURE } & 27\end{array}$

1.12 LIPID COMPOSITION

1.13 MOLECULAR BIOLOGY 39

1.14 INTRODUCTION TO PLASMIDS 45

$\begin{array}{lll}1.15 & \text { PLASMID ISOLATION }\end{array}$

$\begin{array}{lll}1.16 & \text { PLASMID SIZING } & 49\end{array}$

$\begin{array}{ll}1.17 \text { RESTRICTION MAPPING } & 50\end{array}$

$\begin{array}{ll}1.18 \text { PLASMID COPY NUMBER } & 50\end{array}$

$\begin{array}{lr}1.19 \text { METHANOGEN PLASMIDS } & 52\end{array}$

SECTION II

METHODS AND MATERIALS

2.1 ANAEROBIC CELL CULTURE AND GROWTH 54 CONDITIONS

$\begin{array}{lll}2.2 & \text { CELL LYSIS } & 58\end{array}$

$\begin{array}{lll}2.3 & \text { PLASMID SUPVEY } & 62\end{array}$

$\begin{array}{lll}2.4 & \text { PLASMID ISOLATION }\end{array}$

2.5 PLASMID PDDK CHARACTERIZATION 64 


\section{SECTION III}

\section{RESULTS AND DISCUSSION}

3.I CELL LYSIS 66

3.2 SUSPECTED METHANOGEN PLASMIDS AND A NOVEL $\begin{array}{ll}\text { METHANOGEN PLASMID } & 76\end{array}$

$\begin{array}{lll}3.3 & \text { ISOLATION AND PURIFICATION OF PDDK }\end{array}$

3.4 PDDK CHARACTERIZATION 82

SECTION IV

4.1 CONCLUSIONS AND FUTURE PROSPECTS 92

\section{APPENDICES}

APPENDIX I SOUTHERN BLOT PROTOCOL

APPENDIX II HYBRIDIZATION WITH DIGOXIGENIN

-LABELED PROBES

96

REFERENCES

101 


\section{LIST OF TABLES}

TABLE DESCRIPTION

PAGE

TABLE I ABBREVIATIONS xi

TABLE 2 TAXONOMY OF METHANOGENIC BACTERIA 7

TABLE 3 SUMMARY CHARACTERISTICS OF METHANOGENIC BACTERIA

TABLE 4 DEGREE OF LYSIS OF FROZEN-THAWED METHANOGEN CELLS

68

TABLE 5 FRAGMENT SIZES USED TO CALCULATE RESTRICTION MAP 


\section{LIST OF FIGURES}

FIGURE DESCRIPTION

PAGE

FIGURE I THE PRIMARY KINGDOMS 4

FIGURE II PATHWAY FOR METHANE FORMATION 23

FIGURE III THE STRUCTURE OF PSEUDOMUREIN 33

FIGURE IV MAJOR LIPIDS OF ARCHAEOBACTERIA 37 


\section{LIST OF PHOTOGRAPHIC PLATES}

PLATE DESCRIPTION

PAGE

PLATE 1 ANAEROBIC MEDIA APPARATUS

56

PLATE 2 LYSIS OF METHANOGEN CELLS FRESH

VS. FROZEN

69

PLATE 3 PRONASE-INDUCED LYSIS (\%)

71

PLATE 4 GEL ELECTROPHORESIS OF EXTRACTED DNA FROM METHANOGENS

PLATE 5 TOTAL CHROMOSOMAL ELECTROPHORESIS

OF GP6

PLATE 6 ELECTROPHORESIS OF PDDK

PLATE 7 RESTRICTION FRAGMENT ANALYSIS OF PDDK

SINGLE AND DOUBLE DIGESTS

PLATE 8 i. AUTORADIOGRAM OF PROBED (Bgli)

SOUTHERN BLOT

PLATE 8 ii. AUTORADIOGRAM OF PROBED (EcoRI)

SOUTHERN BLOT

PLATE 9 RESTRICTION FRAGMENT MAP

90 


\section{TABLE OF ABBREVIATIONS}

SYMBOL

tRNA

rRNA

$\mathrm{CsCl}$

EtBi-

CCC

ABE BUFFER

EDTA

DTT

SDS
DESCRIPTION

transfer RNA

ribosomal RNA

cesium chloride

ethidium bromide

covalently closed circular

ammonium bicarbonate, EDTA

ethylenediaminetetraacetic acid disodium salt

dithiothreitol

sodium dodecyl sulphate 


\section{SECTION 1}

\section{LITERATURE REVIEW}

\subsection{ARCHAEOBACTERIA}

Our basic concept of life for many years divided cells into two groups: etkaryotes, cells with a well defined nucleus and prokaryotes (eubacteria), which do not have such a nucleus. This held true until in the late 1970's a long known group of organisms were intensively studied and did not seem to belong to either of these basic categories (Woese, 1987; Woese and Wolfe, 1985; Kandler, 1982, Kandler and Zillig. 1986; Woese and Olsen, 1986; Fox, 1980). These organisms are prokaryotic in nature as they do not have a nucleus and morphologically resemble eubacteria. They also have many biochemical features and structural similarities in certain large molecules which structurally resemble eukaryotes. They are as different from prokaryotes as they are from eukaryotes. It was therefore decided to place these organisms in a third lineage, Archaeobacteria (Fig.I). The archaeobacteria (archaebacteria) were defined as a separate "urkingdom" among the eukaryotes and eubacteria (Konig, 1988). Recently, Woese et al. (1990) have proposed that these organisms be given domain status as the Archaea, distinct from the Domains of Bacteria and Eucaryota (Fig.I.i).

The Archaeobacterial phylogeny, based primarily on homologies of partial and complete sequences of the $16 \mathrm{~S}$ ribosomal ribonucleic acid (rRNA), and supported by a host of morphological and biochemical data, appeared as a distinct group. The 
prokaryotes were seen to be comprised of two distinct groups: eubacteria, which consist of the traditional bacterial groups including the photosynthetic bacteria, blue-green or cyano-bacteria, actinomycetes and spirochetes; and the archaeobacteria. The archaeobacteria consists of two main phylogenetic branches; the first includes the methanogenic bacteria, the extremely halophilic bacteria, Thermoplasma spp., and the extremely thermophilic archaebacteria, thermoacidophiles (Jones, 1987); and the second branch contains the sulphur reducing bacteria Sulfolobus and the thermophiles, Thermoproteus, Pyrodictium, Desulfurococcus. Methanogen phylogeny is not as compact as the second group as they show much more phenotypic diversity. The archaeobacteria share a number of features with both the eubacteria and the eukaryotes, but they also possess some unique and diverse characteristics (Konig, 1988) with respect to their morphology, nutritional requirements, cell wall composition, and optimal growth temperatures.

Archaeobacteria are terrestrial and dquatic microbes, occurring in anaerobic, hypersaline, hydrothermal and geothermal environments as well as in the digestive tracts of animals and man. They consist of aerobes, anaerobes and facultative aerobes. Archaeobacteria range from mesophilic to thermophilic environments. They have unique biochemical properties including the presence of ether-linked phytanyl lipids, the absence of murein in the cell wall, unique transfer RNA (tRNA) and ribosomal RNA (rRNA) chemical composition and sequence (Jones et al., 1987; Brown et al., 1989).

This thesis will specifically examine the phylogeny, biochemistry and molecular biology of the group of strict anaerobic archaeobacteria called methanogens. It will 
address applied problems of cell lysis and DNA purification as well as introduce a novel plasmid. The reason for carrying out this research lies in the unique properties of these organisms; membrane and cell wall components, biochemistry, methane production and their role in the anaerobic decomposition of organic matter. The study of methanogens and the potential genetic engineering of these organisms has importance in the understanding of methane production and cycling, as well the biological remediation of xenobiotic and toxic compounds. Methanogens also promise to be rewarding in other areas of interest such as applications in the pharmaceutical and cosmetic industries (Sprott et al., 1992).

Methane biogenesis is an important process in the global cycling of nutrients and the methanogens inhabit environments where other organisms may be absent due to the extreme anaerobic conditions. In these environments where sulfate and nitrate are absent, carbon dioxide is the terminal electron acceptor in the decomposition of organic matter (Whitman, 1985). Methanogens are also microorganisms of industrial importance. They catalyze the final steps in the anaerobic biodegradation of organic compounds to methane, the biotechnological process used worldwide to detoxify and dispose of waste material and to convert biomass into a convenient, combustible fuel (Resve, 1988). As W.: the potential of thermostable enzymes and biocatalyst sources from the extremely thermophilic species make these organisms industrially important. Therefore methanogens are industrially, biochemically and environ nentally important, which not only legitimizes this work but also indicates the need for more intensive basic research. 


\section{FIGURE I. THE PRIMARY KINGDOMS}

The figure shown here represents an unrooted phylogenetic tree for the three urkingdoms. This distance matrix tree is calculated from the aligned sequences of homology between known sequences of 16s rRNA/18s rRNA (Woese and Olsen, 1986). The distance measure bar corresponds to 0.1 mutational events per sequence position.

\section{FIGURE I i. UNROOTED PHYLOGENETIC TREE FOR THE THREE PROPOSED DOMAINS}

The tree shown here represents the three proposed domain designations of Archaea, Eucarya and Bacteria, branch order and branch length are based upon rRNA sequence comparisons. The numbers on the branch tips correspond to the following groups of organisms, Bacteria: 1) the Thermotogales, 2) the flavobacteria and relatives, 3) the cyanobacteria, 4) the purple bacteria, 5) the Gram + bacteria, and 6) the green non-sulfur bacteria, Archaea the kingdom Crenarchaeota: 7) the genus Pyrodictium and 8) the genus Thermoproteus; the kingdom Euryarchaeota: 9) the Thermococcales, 10) the Methanococcales, 11) the Methanobacteriales, 12) the Methanomicrobiales, and 13) the extreme Halophiles, Eucarya: 14) the animals, 15) the ciliates, 16) the green plants, 17) the fungi, 18) the flagellates, and 19) the microsporidia (Woese et al., 1990). 
I.

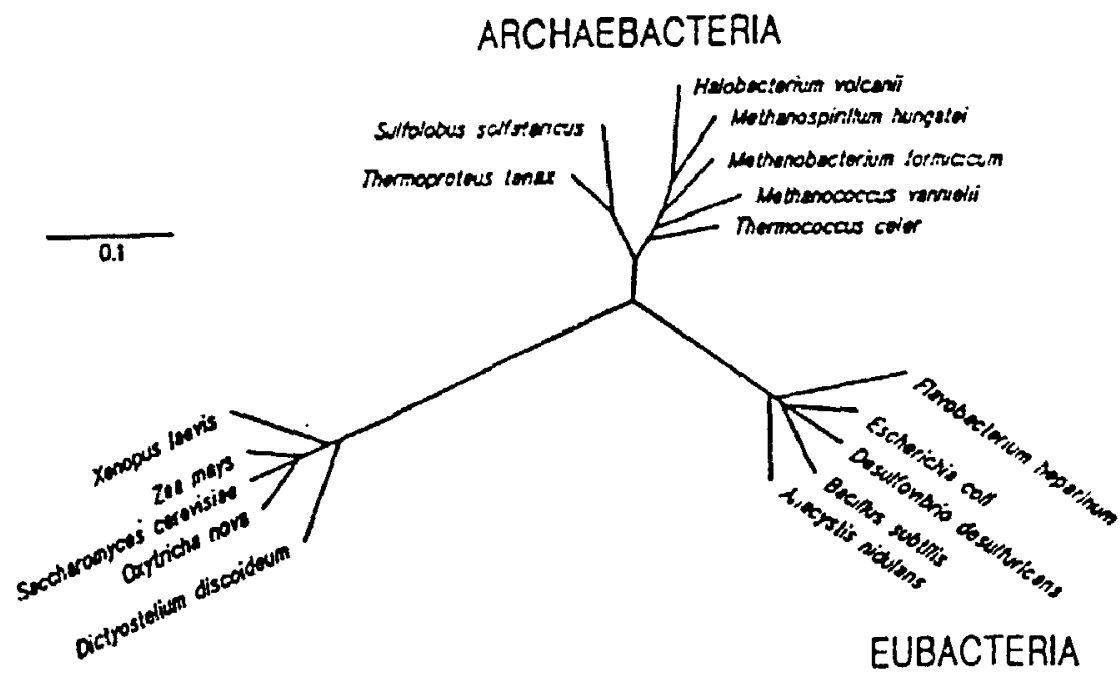

EUKARYOTES

Ii.

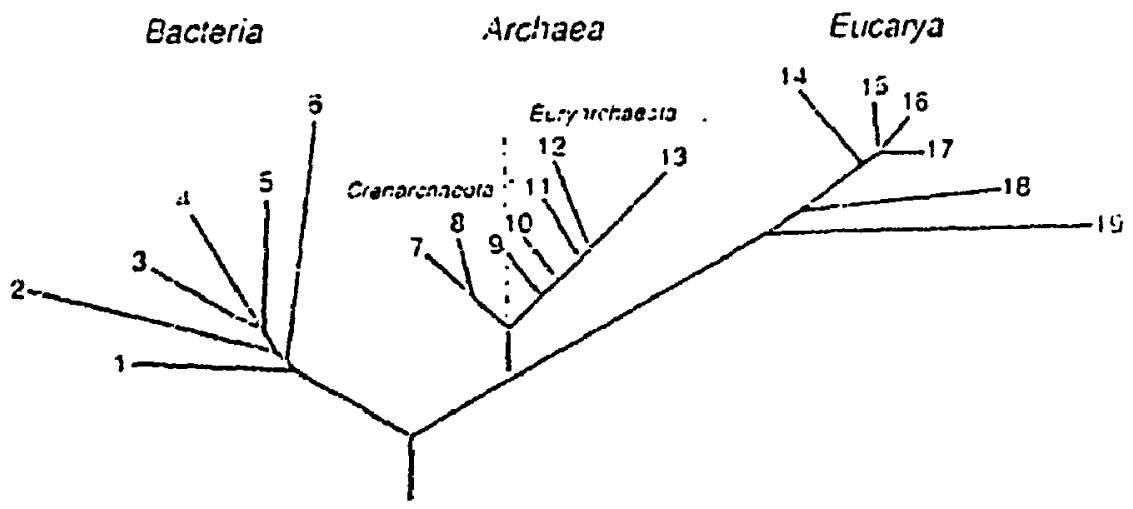




\subsection{METHANOGENIC ARCHAEOBACTERIA}

Methanogens differ in many respects from other prokaryotes. They are unique with regard to their autotrophic metabolism, utilizing $\mathrm{CO}_{2}$ and $\mathrm{H}_{2}$ as their main carbon and energy sources. Some species also use other $C_{1}$ or $C_{2}$ compounds such as formate, acetate, methanol, and methylamines as electron donors. They contain unique cofactors coenzyme $M$, methanofuran, methanopterin, component $B$ and $F_{420}$ mediating the methyl transfer and the primary reduction process of the reduction of $\mathrm{CO}_{2}$ to methane and are obligately anaerobic. Their $16 \mathrm{~S}$ rRNA shows very little similarity to that of other prokaryotes. The occurrence of unique IRNA and $5 \mathrm{~S}$ TRNA in the translation mechanisms are a few of the variations. Methanogens contain a diverse array of morphological forms such as long rods, lancet shaped rods, cocci, planar cells, and cuboid packets (Konig, 1988). They are widely distributed in anoxic environments such as fresh water sediments, marine sediments, sewage sludge, soil, geothermal heated areas and the intestinal tracts of human beings and animals. Methanogenic bacteria are phylogenetically as distant from other bacteria and cyanobacteria as they are from eukaryotic organisms. 


\subsection{TAXONOMY}

In 1979, the taxonomy of the methanogenic bacteria was reorganized to reflect the phylogenetic relationships determined by $16 \mathrm{~S}$ rRNA sequence analysis (Balch et al., 1979). Methanogens are comprised of three major taxa no closer to one another than to the group of extreme halophiles; however, their exact branching order could not be settled by the cataloging approach or by $5 \mathrm{~S}$ IRNA sequence analysis. Therefore it was proposed that the methanogens form a deeply branched single phylogenetic unit that exclude the halophiles (Woese and Olsen, 1986) (Fig.l). The group contains three orders, six families, and eleven genera (Tabie II).

\section{TABLE II TAXONOMY OF METHANOGENIC BACTERIA} (Whitman, 1985; Konig, 1988: OCM, 1990)

$\mathrm{Mol} \% \mathrm{G}+\mathrm{C}$

Order I. Methanobacteriales

Family I. Methanobacteriaceae

Genus I. Methanobacterium $32-50$

Genus II. Methanobrevibacter

27-32

Genus III. Methanosphaera 26

Family II. Methanothermaceae

Genus I. Methanothermus

Order II. Methanococcales 
Family I. Methanococcaceae

Genus I. Methanococcus

Order III. Methanomicrobiales

Family 1. Methanomicrobiaceae

Genus 1. Methanomicrobium

Genus II. Methanogenium

$51-61$

Genus III. Methanospirillum

46-50

Genus IV. Methanoculleus

$54-61$

Family II. Methanosarcinaceae

Genus I. Methanosarcina

$41-43$

Genus II. Methanothrix (Methanosaeta)

52

Genus III. Methanolobus

40

Genus IV. Methanococcoides

Genus V. Methanohalophilus

Genus VI. Methanohalobium

Family III. Methanoplanaceae

Genus I. Methanoplanus

Family IV. Methanocorpusculaceae

Genus I. Methanocorpusculum

48

These determinations were based on 16 S rRNA homologies and are consistent with a considerable amount of descriptive data including cell wall structure, morphology, 
lipid structure, mol $\% \mathbf{G}+\mathrm{C}$, and nutrition. As new isolates are being discovered which appear to represent new genera, this phylogeny is known to be incomplete.

\subsection{DIVERSITY OF METHANOGENS}

Methanogens are obligate anaerobes which share the common property of producing chemolithotrophically or heterotrophically methane as a metabolic product (Jones, 1985; Konig, 1987). Although metabolically restricted, the methanogens exhihit extreme habitat diversity; species have been isolated from virtually every habitat in which anaerobic biodegradation of organic compounds occurs, including freshwater and marine sediments, digestive and intestinal tracts of animals, and anaerobic waste digesters (Jones et al., 1987). Additional isolates have been obtained from extreme environments such as geothermal springs and both shallow and deep-sea hydrothermal vents. Physiologically methanogens contain representatives of extremely thermophilic, moderately thermophilic and mesophilic species (Table III). Although among methanogens there are heterotrophic and autotrophic representatives all presently appear to be organotrophic. They have been found to consist of neutrophiles, alkalophiles and acidophiles (implied by biogenesis of $\mathrm{CH}_{4}$ in peat samples of pH 2.5, Williams and Crawford, 1985). There have however been no barophiles isolated yet. 
The diversity of methanogens is also apparent in their morphology, most morphological types are represented including cocci, groups of cocci (pseudosarcina), rods of various lengths and configurations, and spirillum (Table III).

TABLE III SUMMARY CHARACTERISTICS OF METHANOGENIC

ARCHAEOBACTERIA (modified from Jones et al., 1987)

\begin{tabular}{rr} 
METHANOGEN MORPHOLOGY SUBSTRATES & G+C TEMP \\
& OPT.$\quad$ OPT. \\
\hline
\end{tabular}

ORDER
A. Nethanobacteriales
FAMILY
I. Methanobacteriaceao
GENUS

1. Methanobacterium
M. Formicicum Rod By formate $40.7 \quad 37 \quad 7.0$ pseudomurein
M. bryantif Rod $\mathbf{B}_{2}$
M. thermoautotrophicum Rod $\mathbf{B}_{2}$
$32.7 \quad 38 \quad 7.0$ pseudomurein
$49.7 \quad 65-70 \quad 7.2-7.6$

M. espanolae

$\operatorname{Rod} \quad \mathbf{B}_{2}$

34

pseudomurein

$\mathbf{B}_{\mathbf{2}}$

35

$5 \cdot 6-6 \cdot 2$

pseudomurein

1i. Methanobrevibacter

M. smithii

Rod

B, formate

31

38

$6.9-7.4$ 
pseudomurein

M. arbophilicus

Rod

$\mathbf{H}_{2}$

$29 \quad 30-377.5-8.0$

pseudomurein

II. Methanothermaceae

i. Methanothermus
M. fervidus
Rod
$\mathrm{H}_{2}$
33
83
6.5 pseudomrain,
s-layer, protein

ORDER

B. Methanococcales

FAMILY

I. Methanococcaceae

GENUS

i. Methanococcus
M. voltae
Coccus $\mathrm{H}_{2}$, formate
29.6
$32-40$
6.7-7.4 protein
s-layer
M. jannaschii
Coccus $\mathrm{H}_{2}$
31
85
6.0 protein

$$
\text { s-layer }
$$

ORDER

c. Nethanomicrobiales

FAMILY

I. Methanomicrobiaceae

GENUS

i. Methanospirillum

M. hungatei spirilium $\mathrm{H}_{2}$, formate $45 \quad 30-376.6-7.4$
protein sheath, s-layer

II. Methanosarcinaceae

i. Kethanosarcina

M. mazei

coccus $\mathrm{H}_{2}, \mathrm{Me}, \mathrm{AC}$,

$\begin{array}{llll}\text { MeNH }_{2} & 42 & 40 & 6.0-7.0\end{array}$


M. barkeri

$$
\begin{aligned}
& \text { Coccus, } \mathrm{B}_{2}, \mathrm{Me}, \mathrm{AC} \text {, } \\
& \begin{array}{lllll}
\text { packeta2 } & \text { MeNH}_{2} & 39 & 35 & 7.0
\end{array} \\
& \text { HPS, protein }
\end{aligned}
$$

M. acetivorans

ii. Methanosaeta

M. concilli

Rod

Ac

$49 \quad 35-40 \quad 7.1-7.5$

protein sheath

note: this table comprises species which were used in this thesis, this table is therefore not a complete listing of all genera.

Abbreviations: Me, methanol; $\mathrm{MeNH}_{2}$, methylamines; Ac, acetate; HPS, heteropolysaccharide.

' growth as cocci or packets depends on growth phase i.e. whether grown on liquid vs. solid media.

\subsection{METHANOBACTERIALES}

The order Methanobacteriales contains two families, Methanobacteriaceae and Methanothermaceae with thirteen species found in two genera (Table II). All methanogens containing pseudomurein in their cell walls are in this group. They stain Gram + , with diverse nonmotile morphologies, rods, lancet shape and cocci. Cells occur 
singly, in chains, or in packets. cell division is by binary fission. In all members tested $\mathrm{C}_{20}$ and $\mathrm{C}_{40}$ isopranyl glycerol ethers are abundant. They are mesophilic to thermophilic. Members of the family Methanobacteriaceae are short and long, rod shaped organisms. The temperature growth optimum is between $37-70^{\circ} \mathrm{C}$. Presently ihe energy sources known for these organisms is $\mathrm{H}_{2}$ or formate and the cell walls do not contain an $S$ layer. Three genera are in the family, Methanobrevibacter, Methanobacterium and Methanosphaera. The first occurring as short lancet shaped rods which often form pairs or chains. All members described are mesophilic and grow at neutral pH. DNA base composition is $27-32 \mathrm{~mol} \% \mathrm{G}+\mathrm{C}$. Methanobacterium cells are straight, long, sometimes irregular rods. DNA base composition is $50 \mathrm{~mol} \% \mathrm{G}+\mathrm{C}$. The cells are nonmotile and found mesophilic to thermophilic. Methanosphaera are coccoid cells found singly or in packets depending on the growth phase. Carbon sources include $\mathrm{H}_{2}, \mathrm{CO}_{2}$, and acetate. The DNA base composition is $26 \mathrm{~mol} \% \mathrm{G}+\mathrm{C}$.

The family Methanothermaceae contains one genus Methanothermus. Cells occur as long rods growing optimally above $80^{\circ} \mathrm{C}$. The cell wall is composed of a pseudomurein layer and a glycoprotein S-layer. The DNA base composition is $33 \mathrm{~mol} \%$ G+C. The cells occur only in extremely thermophilic environments. Hydrogen and $\mathrm{CO}_{2}$ are growth substrates. 


\subsection{METHANOCOCCALES}

The order Methanococcales contains one family, Methanococcaceae and one genus Methanococcus. This genus contains eight species all having a morphology of irregular cocci, which stain Gram-. Cell walls are composed primarily of non-glycosylated proteinaceous compounds which allow these organisms to lyse easily in weak detergents. The isoprany! glycerol ether $C_{20}$ (except for one species) is abundant but the $C_{40}$ isopranyl ether is usually absent. DNA base composition ranges from $31-40 \mathrm{~mol} \% \mathrm{G}+\mathrm{C}$. All cells are motile with the exception of Methanococcus delrae. All the isolates of this group are from coastal and marine environments, they are mesophilic to extremely thermiphilic. The requirement for $\mathrm{NaCl}$ varies greatly among the species. Among the members, most use $\mathrm{H}_{2}$ and formate as electron donors and can grow autotrophically (Whitman, 1985). As well most have a growth requirement for selenium.

\subsection{METHANOMICROBIALES}

The order Methanomicrobiales contains four families, Methanomicrobiaceae, Methanosarcinaceae, Methanoplanaceae and Methanocorpusculaceae and twelve genera.

The first family, Methanomicrobiaceae contains four genera Methanomicrobium, Merhanogenium. Methanospirillum and Merhanoculleus which are restricted to $\mathrm{H}_{2}$ and formate as electron donors. All morphologies are represeıted in this order rods, 
spirillum, and irregular cocci. Cells stain Gram- and Gram + . The cell walls are proteinaceous, with the lipid content of the only one investigated found to contain both $\mathrm{C}_{20}$ and $\mathrm{C}_{40}$ isopranyl glycerol ethers (Kushwaha et al., 1981). All members use both $\mathbf{H}_{2}$ and formate as electron donors, $\mathrm{H}_{2} / \mathrm{CO}_{2}$, acetate, methanol or methylamines can also serve as carbon sources. Isolates have been found in marine and freshwater sediments. The mol\% G+C ranges from 45.0-61.2. Methanomicrobium are short rods with a subunit cell envelope. Acetate is required for growth and they have complex growth requirements. The DNA base composition is $45-49 \mathrm{~mol} \% \mathrm{G}+\mathrm{C}$. Methanogenium occur as highly irregular cocci. Substrates are $\mathrm{H}_{2} / \mathrm{CO}_{2}$ and formate, most strains requiring acetate as a carbon source. The DNA base composition is $51-61 \mathrm{~mol} \% \mathrm{G}+\mathrm{C}$. Methanospirillum are rods which form long filaments. Cells can be surrounded by a SDS-resistant protein sheath, and single cells are septated by spacers. $C_{20}$ isopranyl diether and $\mathrm{C}_{40}$ isopranyl tetraethers are present. The DNA base composition is 50 $\mathrm{mol} \% \mathrm{G}+\mathrm{C}$.

The family Methanosarcinaceae, contains six genera Methanosarcina, Methanolobus, Methanococcoides Methanothrix (Methanosaeta), Methanohalophilius and Methanohalobium. Cells are coccoid occurring singly or in clumps. Cells stain Gram+ or Gram-. Methanol or methylamines serve as carbon and energy sources. Some species also use $\mathrm{H}_{2} / \mathrm{CO}_{2}$ or acetate. The genus Methanosarcina can grow on acetate, methylamines, methanol and most species on $\mathrm{H}_{2} / \mathrm{CO}_{2}$; formate is not used. Most species stain Gram + and contain heteropolysaccharide cell walls. DNA base compusition is 40$43 \mathrm{~mol} \% \mathrm{G}+\mathrm{C}$. Metinanolobus are obligate methylotrophs, cells can only use methanol 
and methylamines as energy and carbon sources. The DNA base composition is 40 mol\% G+C. Methanococcoides share 2-4\% DNA homology with Methanolobus and share the above description. $\mathrm{C}_{20}$ isopranyl diethers only are found in the cytoplasmic membrane. The DNA base composition is $42 \mathrm{~mol} \% \mathrm{G}+\mathrm{C}$. Methanothrix (Methanosaeta) cells are thick Gram- rods which form long filaments. Several cells can be surrounded by a SDS-resistant protein sheath. Acetate serves as the sole substrate. Formate is oxidized. $\mathrm{C}_{20}$ isopranyl diethers and hydroxydiether lipids were found in the cell envelope. The DNA base composition is $49-52 \mathrm{~mol} \% \mathrm{G}+\mathrm{C}$.

The family Methanoplanaceae contains one genus Methanoplanus, which occur as sharp sided plate-shaped cells which stain Gram-. They possess a glycoprotein Slayer. Acetate is required as a carbon source for growth. $\mathrm{H}_{2}$ and formate serve as electron donors. The DNA base composition is $48 \mathrm{~mol} \% \mathrm{G}+\mathrm{C}$.

The family Methanocorpusculaceae also contains only one genus Methanocorpusculum, which occur as small mesophilic cocci( $<1$ um). They stain Gram-. $\mathrm{H}_{2} / \mathrm{CO}_{2}, \mathrm{CO}_{2}$, formate and 2-propanol/CO $\mathrm{CO}_{2}$ serve as substrates. Acetate, yeast extract and tungstate are required for growth. The DNA base composition is $48 \mathrm{~mol} \% \mathrm{G}+\mathrm{C}$. 


\subsection{ENERGY METABOLISM: METHANOGENESIS}

A brief description of energy metabolism and assimilatory pathways is included here as this information is important for an understanding of the organisms and to proceed with genetic evaluation of these organisms.

Methane-producing microorganisms are ubiquitous and functional in a wide variety of anaerobic environments. The magnitude of methanogen activity in the global cycling of methane is not fully appreciated. It is important to recognize that biogenic methane released to the atmosphere is only a small fraction of that actually produced because the methanogenic bacteria oxidize most of it before it ever reaches the atmosphere. The methane that does reach the atmosphere is equivalent to $0.5 \%$ of the annual biological production of dry organic matter, methane is thus one of the most abundant organic compounds on earth, and the microbes that produce it play a major role in the cycling of carbon (Frea, 1982). As well, methanogens play an important role in the anaerobic degradation of organic compounds (Wolfe, 1971). Methane is one of the most abundant organic compounds on earth, and the microbes that produce it play an important role in the cycling of carbon (see Kirsop, 1985 for a review of methanogenesis and Blaut, 1990 for a review of the energetics of methanogens). Microorganisms producing methane as the end product of metabolism benefit by the production of cellular energy during the catabolism of extremely simple substrates at low reduction potentials (Jones et al., 1987). 
Methanogens possess a unique mode of energy metabolism: methane generation. Although some anaerobic eubacteria evolve small amounts of methane during their normal metabolism (Postgate, 1969), only methanogenic archaeobacteria are known to couple methane synthesis to energy generation (Jones et al., 1987). Much effort has been devoted to studying the biochemistry and energetics of methanogenesis (Daniels et al, 1984; Keltjens, 1984; Jones et al, 1987, Blaut et al., 1990; Thauer, 1990; Gottschalk and Blaut, 1990) and genes that encode enzymes involved in methanogenesis (Shuber et al, 1986; Allmanberger et al, 1986; Bokranz and Klein, 1987; Cram et al, 1987; Bokranz et al, 1987; Reeve, 1988; Weil et al, 1988; Weil, 1989). Methane formation occurs only under strictly anaerobic conditions and thus methanogenesis is restricted to habitats which are highly anoxic (of low oxidation-reduction potentials). So far, all known methanogens are obligate methane producers, and no secondary energy sources have been identified (Whitman, 1985). The compounds which serve as the substrates methanogens use are produced as end products of various eubacterial and eukaryotic fermentations, and anaerobic oxidations of both complex and simple compounds, these compounds are $\mathrm{H}_{2}$, $\mathrm{CO}_{2}$, formate, acetate, methanol and methylamines (Jones et al., 1987). Carbon dic.ide is a nearly universal substrate for methanogens, the needed electrons usually being derived from $\mathrm{H}_{2}$. However, as noted previously a variety of other substrates are converted to methane by certain methanogenic species. Wnen growing on $\mathrm{H}_{2}+\mathrm{CO}_{2}$, the methanogens are autotrophic with $\mathrm{CO}_{2}$ serving as both carbon source and electron acceptor. It has been determined from biochemical studies that the typical electrontransport systems of methanogenesis varies in the molecular carriers to traditional carriers 
of other anaerobic respiratory processes such as sulfate and nitrate reduction. The electron carriers in methanogenesis require a host of specific coenzymes unique to methanogenic bacteria which serve as cofactors for enzymes which sequentially reauce various $\mathrm{C}-1$ intermediates starting with $\mathrm{CO}_{2}$ and eventually yielding $\mathrm{CH}_{4}$.

The following describes the unique coenzymes involved in methanogenesis, their structures and functions. Secondly, the pathways to methane from $\mathrm{CO}_{2}$, formate, methanol and methylamines, and acetate are outlined.

\subsection{UNIQUE COFACTORS}

The peculiarities of methanogenesis and its coupling to energy conservation led to the evolution of a number of very specialized and unusual coenzymes (Balch et al, 1979; Wolfe, 1985; Jones, 1987; Konig, 1988). To investigate regulation of gene expression it is necessary to identify regulatory units and characterize signals for transcriptional initiation and termination (Konheiser et al., 1984). Structural genes coding for subunits of enzyme complexes lend themselves for studies of gene regulation, since coordinate expression of these genes is most likely unless one or more of the subunits have multiple functions in different metabolic pathways (Konheiser et al., 1984). The following is a description of some of these unique cofactors.

\section{Coenzyme $\mathbf{F}_{20}$}

Cells of methanogens can be identified by their strong autofluorescence under oxidizing conditions. The major contributors to this phenomena are coenzyme $F_{420}$ and 
the methanopterin derivatives (Jones et al., 1987). The coenzyme $F_{420}$ of methanogens is a deazariboflavin derivative substituted with ribitol, phosphate, and glutamyl residues. It is this coenzyme that gives methanogens florescence. $F_{420}$ has been detected in all methanogens but is not found in other organisms with the exception of Streptomyces, Mycobacterium tuberculosis and Nocardia aurantia (Daniels et al., 1985). The function of $F_{420}$ is a low potential electron carrier $\left(E_{\circ}^{\prime}=-340\right.$ to $\left.350 \mathrm{mV}\right)$ for two electron transfer

reactions and partially replaces ferredoxin. $F_{420}$ is a coenzyme of hydrogenase, the formate dehydrogenase and the $\mathrm{CO}$ dehydrogenase systems in methanogens.

\section{$F_{430}$}

$F_{430}$ is a yellow soluble nickel tetrapyrrole which functions in the terminal step of methane reduction, as a part of the methyl reductase system. However, its exact role in the catalytic cycle is not yet clear (Blaut et al., 1990).

\section{Methanofuran and Methanopterin}

Methanofuran, is a low-molecular-weight coenzyme that plays an important role in the first step of methanogenesis from $\mathrm{CO}_{2}$. It functions as a formyl carrier in the first step of the reduction of $\mathrm{CO}_{2}$. The formyl groups are transferred to methanopterin $\left(\mathrm{F}_{432}\right)$, a derivative related to folic acid. Methanopterin exhibits a bright blue fluorescence, and serves a $\mathrm{C}-1$ carrier during the reduction $\mathrm{CO}_{2}$ to $\mathrm{CH}_{4}$.

\section{Coenzyme $M$}

The oxidation of hydrogen and the reduction of $\mathrm{CO}_{2}$ to produce methane by methanogens involves a higher unique biochemistry. Coenzyme $\mathbf{M}$ (Taylor and Wolfe, 1974) is involved in the methyl transfer reactions in methane bacteria. It is the smallest 
known coenzyme and is exceptional in its high sulfur content and acidity. This cofactor is required by the enzyme methyl-coenzyme $M$ reductase present in all methanogens and active in the terminal steps of $\mathrm{CO}_{2}$ reduction to $\mathrm{CH}_{4}$ (Balch et al, 1979). Coenzyme $\mathrm{M}$ is not found in eubacteria or eukaryotes but is found in high levels in all methanogens.

\section{Cyclodiphosphoglycerate}

Cyclodiphosphoglycerate is believed to be involved in the thermoadaptation of enzymes in the group of thermophilic methanogens.

\section{Component B}

Like coenzyme $M$ this cofactor is involved in the terminal step of methanogenesis catalyzed by the methyl reductase system, but its precise role is still unknown. Component $B$ resembles the vitamin pantothenic acid and may serve as an electron donor to the methyl reductase system.

\subsection{METHANOGENIC PATHWAYS}

Despite the common terminal product of the methanogenic metabolism, the pathways leading to methane are different and depend on the substrate utilized (Blaut et al., 1990). The various methanogenic pathways are outlined in the following section. 
METHANOGENESIS FROM $\mathrm{H}_{2}-\mathrm{CO}_{2}$

$$
\mathrm{CO}_{2}+4 \mathrm{H}_{2} \rightarrow \mathrm{CH}_{4}+2 \mathrm{H}_{2} \mathrm{O} \quad \Delta \mathrm{G}_{\mathrm{o}}^{\prime}=-130 \mathrm{~kJ} / \mathrm{CH}_{4}
$$

The pathway of $\mathrm{CO}_{2}$ reduction with molecular hydrogen has largely been elucidated (Figure II). Methane formation from $\mathrm{H}_{2}+\mathrm{CO}_{2}$ is the most common substrate used by almost all methanogens (for reviews see Rouviere and Wolfe, 1988; Jones et al., 1985) and could be considered a type of anaerobic respiration in which $\mathrm{CO}_{2}$ serves as the electron acceptor. In the first step (Fig. II) $\mathrm{CO}_{2}$ is reduced to form formylmethanofuran. The formyl moiety is then transferred to tetrahydromethanopterin $\left(\mathrm{H}_{4} \mathrm{MPT}\right), \mathrm{H}_{2} \mathrm{O}$ is cleaved off giving rise to the formation of methenyl- $\mathrm{H}_{4}$ MPT which in turn is reduced to methylene- $\mathrm{H}_{4} \mathrm{MPT}$ in an $\mathrm{F}_{420}$-dependent reaction. The latter compound is reduced to methyl-H,MPT with the methyl group subsequently being transferred to the coenzyme $M$ in the transferase reaction. Methyl-coenzyme $M$ is reduced to methane in the terminal methylreductase reaction (Blaut et al., 1990).

\section{METHANOGENESIS FROM FORMATE}

$$
4 \mathrm{HCOOH} \rightarrow 3 \mathrm{CO}_{2}+\mathrm{CH}_{4}+2 \mathrm{H}_{2} \mathrm{O} \quad \Delta \mathrm{G}_{\mathrm{o}}{ }^{\prime}=-119.5 \mathrm{~kJ} / \mathrm{CH}_{4}
$$

Formate does not enter the methanogenic $\mathrm{CO}_{2}$ reduction pathway directly; it must tirst be oxidized to $\mathrm{CO}_{2}$ by formate dehydrogenase, the electrons derived by this reaction 
can be used for the reduction steps outlined above for $\mathrm{CO}_{2}$ reduction (Blaut, et al., 1990). Small amounts of hydrogen are produced during formate conversion however molecular hydrogen does not appear to be an intermediate in methanogenesis from formate (Shauer and Ferry, 1980). Formate dehydrogenase purified from Methanobacterium formicicum contains non-heme iron, a molybdoterin cofactor which requires FAD for the reduction of $F_{420}$ (Shauer and Ferry, 1986).

METHANOGENESIS FROM METHANOL AND METHYLAMINES

$$
\begin{aligned}
& \mathrm{CH}_{3} \mathrm{OH}+\mathrm{H}_{2} \mathrm{O} \longrightarrow \mathrm{CO}_{2}+6 \mathrm{H} \\
& 3 \mathrm{CH}_{3} \mathrm{OH}+6 \mathrm{H} \longrightarrow 3 \mathrm{CH}_{4}+3 \mathrm{H}_{2} \mathrm{O} \\
& 4 \mathrm{CH}_{3} \mathrm{OH} \longrightarrow 3 \mathrm{CH}_{4}+\mathrm{CO}_{2}+2 \mathrm{H}_{2} \mathrm{O} \quad \Delta \mathrm{G}_{\mathrm{o}}^{\prime}=-106.5 \mathrm{~kJ} / \mathrm{CH}_{4}
\end{aligned}
$$

The conversion of methanol (equation shown above) and methylamines (equation not shown) is characterized by an oxidative and a reductive branch. In the oxidative branch the methyl groups pre oxidized to $\mathrm{CO}_{2}$, and the reducing power gained fuels the reductive branch. In the reductive branch the methyl groups are transferred to coenzyme $M$, the resulting methyl-CoM is then the substrate of the methyl-CoM methylreductase but differs from the $\mathrm{CO}_{2}$ reduction pathway, where $\mathrm{H}_{2}$ serves as the electron donor, the electrons here are derived from the methyl group oxidation (Fig. II b.) (Blaut et al., 1990). 
THE CONVERSION OF ACETATE

$$
\mathrm{CH}_{3} \mathrm{COOH} \rightarrow \mathrm{CH}_{4}+\mathrm{CO}_{2} \quad \Delta \mathrm{G}_{0}^{\circ}=-32.3 \mathrm{~kJ} / \text { reaction }
$$

The pathway of acetate conversion (Fig. II c.) illustrates that prior to cleavage into $C_{1}$ moieties, acetate has to be activated. In Ms. barkeri, this proceeds by the action of acetate kinase and phosphate acetyltransferase to yield acetyl-CoA. The electrons gained from the oxidation of $\mathrm{CO}$ to $\mathrm{CO}_{2}$ are used to reduce the methyl group to methane (Blaut et al., 1990). 
25

FIGURE II PATHWAYS FOR METHANE FORMATION

A. Pathway of methanogenesis from $\mathrm{H}_{2}+\mathrm{CO}_{2}$.

B. Pathway of methanogenesis from methanol.

$\mathrm{H}_{4}$ MPT, tetrahydromethanopterin; MF, methanofuran; HS-CoM, reduced coenzyme $M ; F_{420} H_{2}$, reduced $F_{4211}$.

C. Pathway of methanogenesis from acetate. [CO], bound $\mathrm{CO}$ 
A

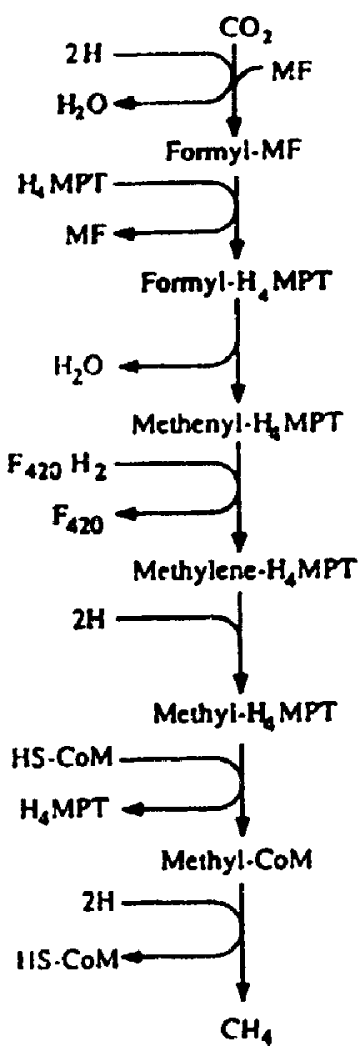

B

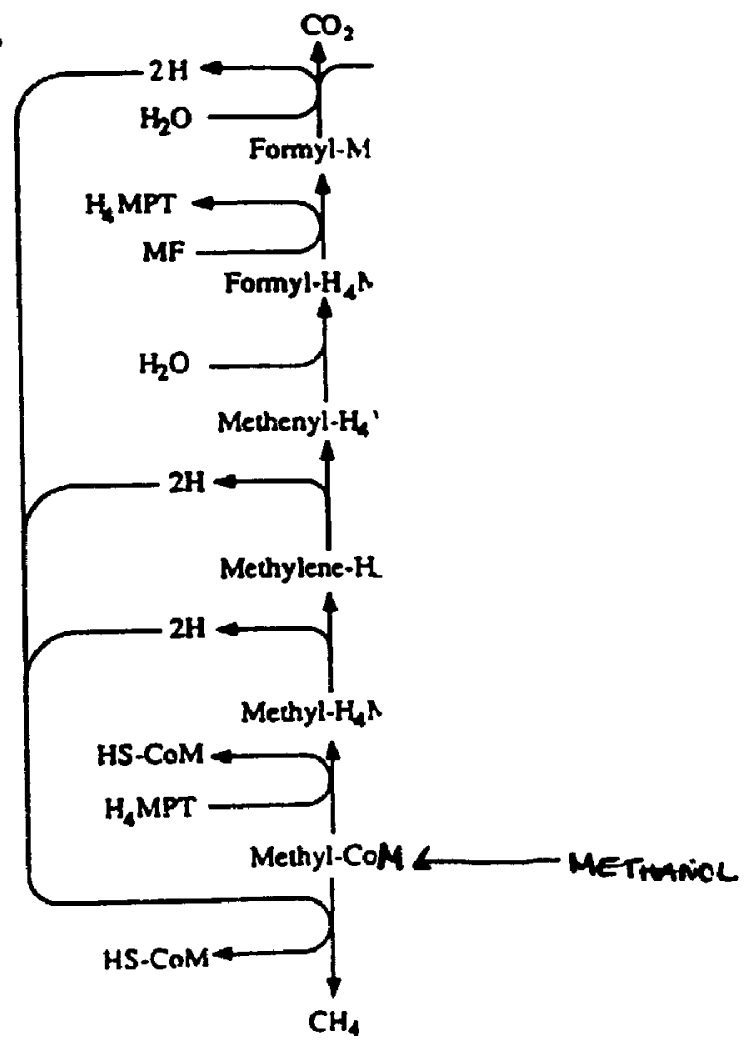

c.

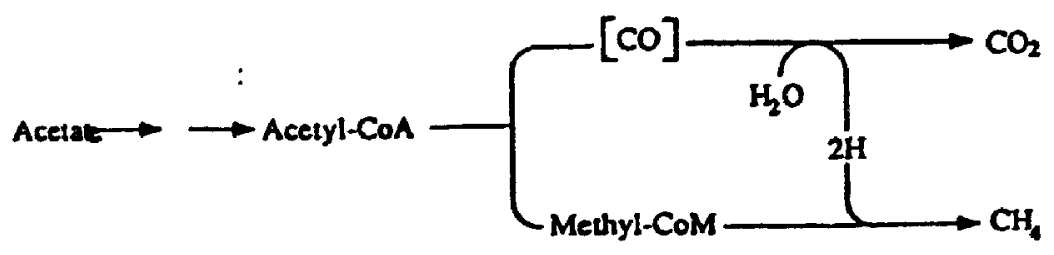




\subsection{CELL WALL STRUCTURE}

The cell envelope structures of the archaeobacteria were one of the first biochemical characteristics studied in detail. From these studies it was apparent that significant differences were present in the archaeobacteria compared to typical bacterial cell envelopes (Kandler and Konig, 1978; Konig, 1988). The discussion of cell wall composition is important to this study as the procedure for lysis of a number of different species is dependent on the structure and composition of the membranes and wall. All archaeobacteria lack murein in the cell envelope, although rare in eubacteria some groups also show this feature e.g.Planctomyces, Pirella, and Mycoplasma (Konig, 1988). Unlike most eubacteria archaeobacteria have no universal cell wall polymer. The unusual chemical composition of the cell envelope of Archaeobacteria show a high degree of resistance against cell wall antibiotics and lytic agents (Konig, 1988). The archaeobacteria have a collage of cell wall types, they stain Gram- and Gram + , they do not contain muramic acid or D-amino acids. The cell walls of the Gram + archaeobacteria consist of pseudomurein and methanochondroitin. All the Grartarchaebacteria have cell envelopes composed of single-layered or more complex crystalline protein or glycoprotein subunits (Konig, 1988). Single S-layers are found in most organisms of the methanogenic branch. The $\mathbf{S}$ layer is commonly a proteinaceous crystalline layer of hexagonally arranged subunits of different molecular weights (Konig and Stetter, 1986). Glycosylated proteins were not found to be present and the amino acid composition was predominantly non-polar. This layes is the only structural element 
outside of the cytoplasmic membrane of most Gram-archaeobacteria (Nuber and Konig, 1986; Sleytr et al. 1986). These S-layers can provide resistance to some of the characteristic environmental conditions these organisms are exposed to such as high salt, low $\mathrm{pH}$, and high temperatures. S-layers can be considered the simplest biological membranes or protein envelopes developed during evolution which can withstand extreme environmental conditions.

Isolation of total cellular DNA for the construction of genomic 'ibraries to clone genes from several species of the methanogenic members of the archaeobacteria domain, has been hindered by the lack of generally applicable lysis method. This is because certain methanogen species contain a cell wall which resists disruption by the traditional chemical and enzymatic methods commonly sed to lyse the Gram + and Gram- species of the eubacteria kingdom.

Methanogens can be classified into several subgroups on the basis of cell wall structure, each exhibiting characteristic behaviors towards various chemicals and enzymes. Cells of the order Methanobacteriales have an electron dense cell wall composed at least in part, of pseudomurein (Konig, 1988). Pseudomurein is not susceptible to degradation by lysozyme (Kandler and Konig, 1978) (see Chapter 2.5.1), but can be degraded by an endc. -ptidase found in extracts of Methanobacterium wolfei (Keiner $e t$ al., 1987). Members of the genera Methanosaeta ('Methanothrix') (Patel and Sprott. 1990), and Methanospirillum of the order Methanomicrobiales occur as long chains of cells with tubular proteinaceous sheaths. These show unusual recalcitrance against the action of chemical agents and lytic enzymes (Kandler and Konig, 1978; 
Beveridge et al., 1985; Patel et al., 1990; Sprott et al., '36). L, is can be achieved by incubation of these methanogens at alkaline $\mathrm{pH}$ with dithiothreitol, whereas other genera proved resistant (Sprott et al., 1979). Other members of Methanomicrobiales (Methanosarcina spp.) have relatively thick cell walls lacking peptidoglycan (Kandler and Hippe, 1977), and are composed of the fibrillar nonsulphated polymer (described in chapter 2.6) methanochondroitin (Kreisl and Kandler, 1986). Many of the methanococci possess a regularly structured, paracrystalline, proteinaceous layer external to tie cytoplasmic membrane (Konig, 1988; Nuber and Konig, 1987). Within the methanogenic bacteria four cell wall types exist. The order Methanobacteriales contains Gram + cells, which can be long rods, lancet shaped rods, or cocci. The cells of all species exhibit an electron dense cell wall sacculi with a tiiickness of approximately $15 \mathrm{~nm}$. These cell walls are composed of pseudomurein, a new type of peptidoglycan. Historically, the cell wall polymer of typical bacteria was referred to as murein, a muramic acid containing peptidoglycan. This term has been replaced by the more general term peptidoglycan. To distinguish between the two polymer types, the structure in methanogens is referred to as pseudomurein. Morphologically eubacterial murein is very similar to pseudomurein however, biochemically they are very different (Balch, 1979). The genus Methanobacterium contains pseudomurein, comprised of two alternating repeats of two amino sugars, $\mathrm{N}$-acetyltalosaminuronic acid and $\mathrm{N}$-acetylglucosamine, the former acid being unique to archaeobacteria while the latter makes up one half of the backbone of eubacterial peptidoglycan (Konig, 1988). The acetyltalosaminuronic acid residues are cross linked by amino acids as are the muramic acid groups in peptidoglycan, but the 
amino acids are all of the L-form rather than the D-amino acid form found on peptidoglycan (Fig.III). The linkage between the amino sugars in pseudopeptidoglycan is chemically a 1-3 bond rather than the 1-4 bond between acetylglucosamine and muramic acid of peptidoglycan. It is this feature which makes lysozyme ineffectual as it's action is on the $B(1-4)$ linkage. Crystalline proteinaceous $S$ layers associated with the peptidoglycan sacculus are a common feature of the Gram + eubacterial bacilli and clostridia, among the Methanobacteriales they were only present in the extremely thermophilic members of the genus Methanothermus.

The genus Methanosarcina have a thick $(200 \mathrm{~nm})$, rigid Gram + wall component (sacculus) consisting exclusively of heteropolysaccharide (Kandler and Hippe, 1977). The major sugars present are $\mathrm{N}$-acetylgalactosamine, glucuronic acid, glucose and a small amount of mannose, a considerable amount of acetate is also present (Konig, 1988). Phosphate and sulfate are absent. Another interesting feature is that the major structural elements, galactosamine and glucuronic acids are similar to the connective tissue component, chondroitin of animal tissues leading to the term methanochondruitin matrix to describe the complex polysaccharide wall of Methanosarcina. It is responsible for the aggregating abilities of this group. The difference between the components is that the polysaccharide of Methanosarcina is not sulfated.

Methanoccocus and Methanomicrobium lack carbohydrate in their cell wall and are composed entirely of several distinct proteins. They contain neither a rigid cell wall (sacculus) nor a sheath, but exhibit an outer non-glycosylated protein layer consisting of hexagonal subunits which disintegrate very easily (Jones et al., 1977; Balch, 1979; 
Konig, 1988). The S-layers vary with species but are heterologous in their molecular weights and in their antigenicity. They have similar chemical and physical stabilities and amino acid compositions. The acidic amino acid compositions are predominantly composed of hydrophobic amino acids (Konig, 1988). These cell surfaces are more primitive structures than those stable crystalline layers.

Methanospirillum and Methanothrix occur in chains forming long filaments. They contain a well defined, double-layer:d wall composed of protein subunits which form a sheath around the organism. Cell wall preparations show no sacculi with rounded ends, but rather cylindrical sheaths of variable length and brittle structure (Kandler and Konig, 1978). The electron dense outer sheath exhibit a distinct fibruiar surface structure, tubular in nature, composed of hoop-like rings. The parallel fibrils are perpendicular to the longer axis of the sheath and breakage occurs along the fibrils (Kandler and Konig, 1978). The outer wall extends as a surface layer from one cell to another and therefore does not participate in septum formation. Although the sheath is composed of mainly protein and carbohydrate (Kandler and Konig, 1978, 1985; Sprott and McKellar, 1980). The individual cells enclosed in a inner envelope are separated from each other by spacer plugs composed of several layers of periodically arranged material (Shaw et al. 1985; Stewart et al. 1985; Beveridge et al. 1986; Patel et al. 1986). The sheath zxhibits unusual resistance to chemical agents and lytic enzymes, treatment with dithiothreitol released spheroplasts but the sheaths remained intact (Sprott et al. 1979). Mercaptoethanol treatment dissassembled the sheaths of Methanospirillum hugatei into separate hoops and soluble glue peptides (Beveridge et al. 1986b; Sprott et al. 1986). 
The hoops can be solubilized by extended incubations with mercaptoethanol and sodium dodecyl sulfate (SDS). 
33

\section{FIGURE III THE STRUCTURE OF PSEUDOMUREIN}

Structure of pseudomurein resembies peptidoglycan in the amino acid cross links of the acetytlalosaminuronic acid, however the amino acids are in the $\mathrm{L}$ form in pseudomurein, as opposed to the D form in peptidoglycan. Shown also is the B (1-3) linkage between the acids, it is this linkage that makes lysozyme ineffectual (this figure is of Methanopyrus, variations do exist between species). 


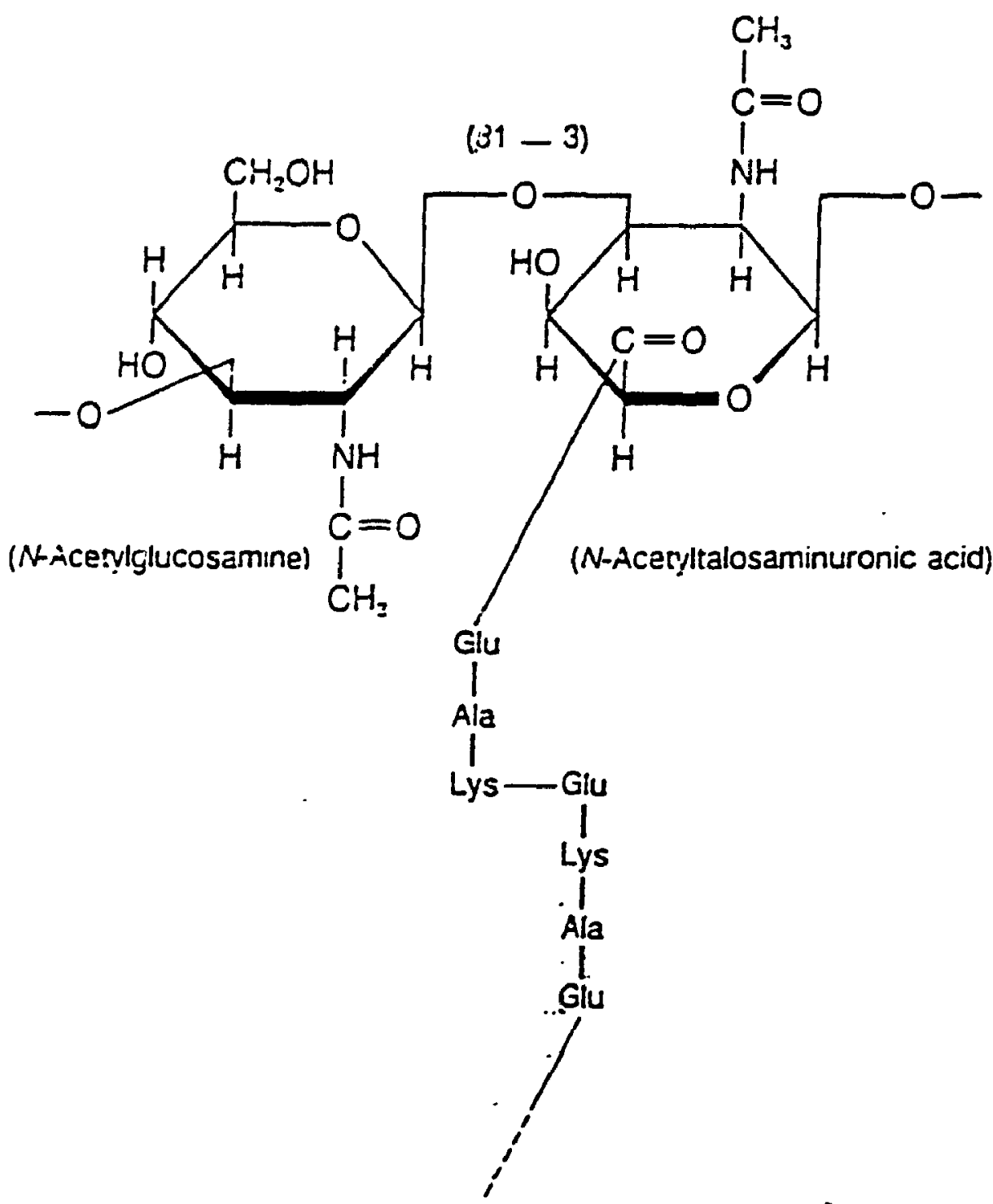

- N-Acetyltalosaminuronic acid - N-Acetylglucósamine- 


\subsection{L.IPID COMPOSITION}

The diversity and unique features of methanogens have been a limiting factor in the development of genetic techniques and the elucidation of genetic features within this group. The lipid structure and components of methanogens is one such feature. Lipid structures may affect the permeability of the celi membrane to the introduction of genetic material. The investigation of methanogen lipids may provide information for the development of techniques of gene transfer or transformation using novel ether lipid liposomes.

A survey of the lipid composition of the methanogens and other bacteria shows that ether-linked polyisoprenoid (branched) chain lipids are the predominant component (Langworthy, 1985). The chemical composition of methanogen and other archaeobacterial membranes differs in their constituents to eubacterial and eukaryotic organisms. The latter organisms' hydrophobic core is composed predominantly of fatty acid ester-linked glycerol lipids. These fatty acid glycerolipids are largely absent from methanogens. The predominant archaeobacterial lipophilic membrane constituents are diphytanyl diether and dibiphytanyl tetraether lipids composed of C20 or C40 carbon units respectively (Langworthy, 1985). The isopranyl glycerol ethers are distinguishing markers for methanogens. Predictions are that the diethers form normal bilayers, and the carbon chain of the tetraether span the membrane forming a monolayer. Seventy to $>$ ninety percent of the lipid content are polar lipids the remaining are neutral lipids. The neutral lipids comprise a wide range $\left(C_{14}\right.$ to $\left.C_{30}\right)$ of isoprenoid hydrocarbons; the 
principle compounds being $\mathrm{C}_{30}, \mathrm{C}_{25}$ and $\mathrm{C}_{20}$ acyclic isoprenoid hydrocarbons with a continuous range of hydroisoprenoid derivatives (see Figure IV for a comparison of methanogen lipid structures). For a broader description covering archaeobacteria in general see a recent review on the subject by Kates, 1988. 


\section{FIGURE IV MAJOR LIPID STRUCTURES OF METHANOGENS}

Major lipids of methanogens: a) glycerol diethers; b) diglycerol tetraethers; c) macrocyclic diether and hydroxydiether (sn-2 and sn-3); d) comparison of the ester linkage of correntional organisms and the ether linkage of archaeobacteria. 
(a) Glycerol diather

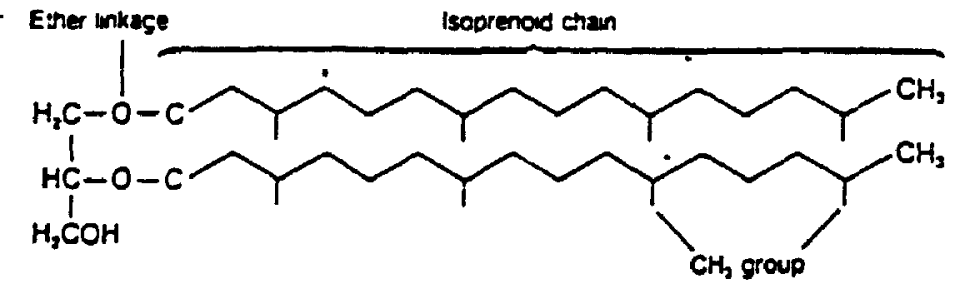

(b) Diglycerol tetrather

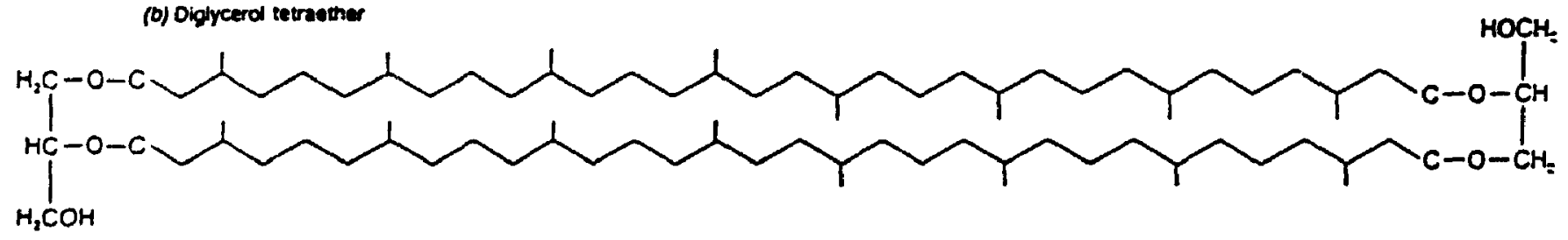

(c)

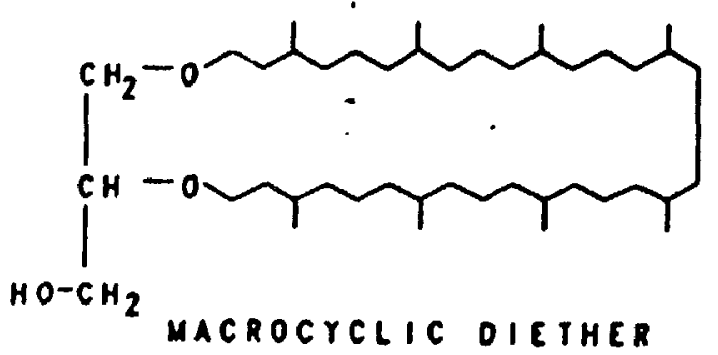<smiles>CC(C)CCCC(C)CCCC(C)CCCC(C)CCCC(C)CCOCC(C)(CO)CCCC(C)CCOCCO</smiles>
HYDROXYOIETHER $(\sin -3)$<smiles>CC(C)CCCC(C)CCCC(C)CCCC(C)CCOCC(C)CCO</smiles>

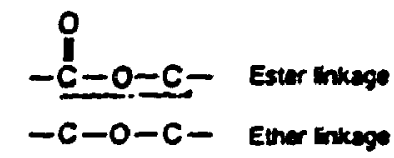




\subsection{MOLECULAR BIOLOGY}

Although these organisms (methanogens) promise to be extremely important in the study of evolutionary biology and potentially in environmental science, much of the study of their genetics has proceeded slowly. This in part is due to their extreme sensitivity to oxygen and their unique physiology. Historically, genetic studies with methanogens are very recent, beginning in 1982 (Reeve et al., 1982 and Bollschweiller and Klein, 1982). As the technical difficulties which have slowed the genetic work on these organisms are overcome, sufficient information is now available (for a review see Brown et al., 1989) to begin to address significant questions dealing with genome characteristics and the mode of gene organization, regulation and expression in the organisms.

The genome size of methanogens ranges from $1.0 \times 10^{4}$ to $1.8 \times 10^{4}$ daltons. These figures were determined by renaturation kinetics of six methanogens. Comparatively the genome size of methanogens is much smaller than Escherichia coli at $2.5 \times 10^{9}$ daltons. The base composition of methanogens is comprised of the standard genetic code of $\mathrm{G}, \mathrm{C}, \mathrm{A}, \mathrm{T}$, with their $\mathrm{G}+\mathrm{C}$ content ranging from $25.8-61 \mathrm{~mol} \%$ (Hamilton and Reeve, 1985; Brown et al, 1989) this corresponds to a range equal to all eubacterial species. Codon usage in methanogens is directly related to the availability of $A+T$ and $G+C$ pairs. Methanogens with low $G+C$ contents preferentially use codons with $A$ or $U$. The codons preferentially used by methanogens are often codons relatively rarely used by $E$. coli, they are AUA, AGA, and AGG (Reeve et al, 1986). 
This resembles codon usage similar to the eukaryote Saccharomyces cereviseae (Reeve et al, 1986).

Sequences of cloned methanogen DNA fragments has revealed that genes are flanked by comparatively more non-repeating $A$ and $T$ rich intergenic sequences. As an example, random cloned DNA fragments from Methanobrevibacter smithii contained an average of $69 \%$ A $+\mathrm{T}$ base pairs (Hamilton and Reeve, 1985). These regions may function as gene spacers but it is not yet known if this is a genetic feature of all methanogens (Harris et al, 1986).

The demonstration that cloned methanogen genes can direct the synthesis of functional enzymes in $E$. coli implies that the standard genetic code is used and does not contain introns. Genes that have been cloned from methanogens and that are expressed in $E$. coli care , but not limited to, hisA, argG, proC, purE as well as genes that encode sub-units of the enzymes methyl-coenzyme-M methyl-reductase and DNA dependent RNA-polymerase, and genes that encode tRNA's and rRNA's (Reeve et. al. 1986). No firm evidence exists to indicate the presence of introns in methanogen genes which encode polypeptides (Reeve, 1988; Reeve et al, 1986). The discovery of a cloning method that does not require expression in $E$. coli may determine the presence of introns (Reeve et al, 1986).

rRNA and IRNA genes as well as protein encoding genes were cloned from various methanogens either by homology with eubacterial genes or by immunochemical methods using antibodies raised against purified proteins. As well, genes cloned from 
methanogens can complement auxotrophic mutants of $E$. coli (Bhatnagar et. al. 1986; Kiener et.al., 1984; Bertani and Baresi, 1987; Jain and Zeikus, 1987).

As shown for multisubunit proteins, e.g., methyl CoM reductase, the genes of the subunits are transcribed in a polycistronic way (Konheiser et al., 1984; Weil et al., 1988; Konig, 1988).

To facilitate genetic analysis cloning vectors are necessary. Generally the most convenient selective markers integrated into such vectors are antibiotic resistances. Unfortunately methanogens are sensitive to a limited number of drugs (Elhardt and Bock. 1982; Possot et al, 1988; Keiner et al, 1986; Jarsch et al, 1983; Keiner et al. 1984: Hummel and Bock, 1985; Hummel et al, 1985; Haas et al, 1986; Bock and Kandler, 1985; Knox and Harris, 1988). Mutants, however, may serve as genetic markers for the development of a genetic system (Rechsteiner et al., 1986; Bertani and Baresi, 1985; Bowen and Whitman, 1987; Jain and Zeikus, 1987; Santoro and Konisky, 1987; Ladspo and Whitman, 1990; Micheletti et al., 1991). Worrel et al.(1988), transferred 5fluorcuracil resistance between strains of Methanobacterium thermoautotrophicum. As well Gerhardt et al.(1990), developed a selectable marker for puromycin resistance and made an important advance toward a shuttle vector with Mipl.

The first step in gene expression involves recognition of DNA sequences necessary for initiation of transcription. Within the classical prokaryotes, the eubacteria, the recognition and binding site of RNA polymerase has been designated as a promoter (Thomm et al, 1989; Gernhardt et al., 1990). Promoter regions in methanogens have been defined primarily by determining transcription initiation sites and identifying 
adjacent conserved sequences. Transcription starts in an $\mathrm{A}+\mathrm{T}$ rich region, as well the terminal signal is found to be in a $A+T$ rich region. A portion of the conserved sequence ACCGAAAAN TTTATATA NTA is similar to the "TATA" box found in eukaryotic promoters. This sequ-nce has been found to be a common element of promoters of stable RNA genes of archaeobacteria (Thomm and Wich, 1988). Although methanogen DNA is expressed efficiently in $E$. coli, it is unlikely that methanogen transcriptional signals are recognized by the eubacterial transcriptional apparatus, since the structure of all methanogen DNA-dependent RNA polymerases are distinct from eubacterial enzymes (Harris et al., 1986). Methanogen DNA-dependent RNA polymerase is composed of 7 to 12 different sized subunit polypeptides, these have complex compositions quite different from those of eubacteria and more closely resemble the eukaryote RNA polymerase Konig, 1988). They are also similar to the eukaryotes in the structural humologies between the individual subunits (Reeve et al, 1986). Methanogen promoter sequences are yet to be fully defined, but it is conceivable that transcription of methanogen DNA in $E$. coli occurs by the recognition of the A-T rich regions as eubacterial-like promoters (Hamilton and Reeve, 1985). All methanogen RNA polymerases are completely resistant to rifampu and streptolydigin antibiotics which inhibıt eubacterial RNA polymerases (Konig, 1988). In fact most antibiotics that specifically affect protein synthesis in eubacteria do not affect methanogen protein synthesis. This is in part due to the macromolecular cell envelope chemistry of methanogens which render these antibiotics ineffectual, therefore they cannot be used as selective agents in genetic experiments invovling methanogens (Reeve et al, 1986). 
Repeated DNA and insertion elements have been investigated and it was found that in Merhanobacterium thermoautotrophicum anproximately $6 \%$ of the genomic DNA consists of repetitive sequences. There is, however, a need for further research in the frequency of rearrangements (Mitchell, 1979). An insertion element ISMI in Methanubrevibacter smithii has been reported which structurally resembles insertion sequences found in the eubacteria (Brown et al, 1989).

Eubacterial genes are frequently contained in polycistronic transcriptional units cr operons. In contrast eukaryotic genes are not usually transcribed into polycistronic mRNAs. Operons and ribosome binding sites in methanogens appear to be eubacteriallike, multigene transcriptional units and therefore encode typical prokaryotic mRNAs. The translation initiation step is co-ordinated by mRNA-16 S rRNA hybridization, similar to the eubacteria.

Although eubacterial and methanogen ribosomes are similar in size, they differ in shape and there are several steps in methanogen protein synthesis which are different, resembling more closely the eukaryotes. In methanogens and eukaryotes the initiating tRNA carries an unmodified methionine unlike the modified eubacterial methionine residue formylmethionine (Dennis et al, 1986). Methanogen bacterial ribosomes contain three rRNA species $23 \mathrm{~S}, 16 \mathrm{~S}$, and $5 \mathrm{~S}$ as found in eubacteria and chloroplasts. The rRNA encoding genes are physically linked and in the same order as the eubacterial 16 S, 23 S and 5 S rRNA's (Reeve et al, 1986). The number of copies of rRNA encoding geiles range from 1 to 4 (Reeve et al, 1986). The archaeobacterial ribosome has a high degree of protein complexity, with the total number of proteins varying between 56 
(Methanohacterium bryantii) to 64 in a Sulfolobus. Comparatively, eubacteria have 52 and there are between $70-85$ in the eukaryotes (Reeve et al, 1986). The ribosomal proteins of methanogens tend to be very acidic.

Sequencing of methanogen tRNA genes has identified clustered genes, genes as individual transcriptional units, and multigene transcriptional units. Most tRNA genes were found to be clustered in a few operons.

Gene transfer systems reported for Archaeobacteria include mating, (Mevarech and Werczberger, 1985; Rosenshine et.al., 1989) and transformation with genomic DNA (Bertani and Baresi, 1897; Cline, et.al., 1989; Worrell, et.al., 1987; Worrel et al., 1988, Sandbeck and Leigh, 1991), plasmid transformation and bacteriophage infection, in Halobacterium (Charlebois, 1987; Hacket and Das Sarma, 1989; Cline and Doolittle, 1987), and transduction(like) gene transfer systems have been found in methanogens (Bertani and Baresi, 1989; Meille et.al., 1990).

A number of extrachromosomal elements as well as restriction enzymes with new restriction sites or consensus sequences have been purified.

It would appear from the current information that gene structure and expression in methanogens follows eubacterial precedents. The long term, successful application of recombinant DNA technologies to the analysis of gene regulation in any biological system requires an efficient transformation protocol. Cloned fragments have elucidated the bas:c structure and organization of genes, but to determine how these genes are regulated in vivo requires the manipulation of these genes in vitro with subsequent reintroduction and expression in viable cells. Methods of gene transfer in methanogens are 
needed to facilitate genetic studies. As these techniques are becoming available the ability to determine the molecular biology of these interesting organisms and their potential benefits is progressing.

\subsection{INTRODUCTION TO BACTERIAL PLASMIDS}

Bacterial plasmids are double-stranded closed circular DNA molecules that range in size from $1.0 \mathrm{~kb}$ to more than $2000 \mathrm{~kb}$ (Rhizobium). They are found in a variety of bacterial species, where they behave as accessory genetic units that replicate and are inherited independently of the bacterial chromosome (Maniatis, 1989). The reasons for studying plasmids are numerous. They have medical importance as they are in part responsible for the resistance of infectious bacteria to antibiotics (Broda, 1979). Plasmids are also of great value as material for studying the structure and function of genetic material. For this there are two virtues plasmids possess; 1) their relatively small size generally in the range of $0.75-100$ megadaltons ( 1 megadalton $=1,500$ base pairs $=1.5 \mathrm{~kb}$ ) sufficient to code for $1-2$ average size proteins, which means they are easy to manipulate in vitro compared to intact bacterial chromosomes, and 2) their host cells can usually survive without them. Therefore the properties conferred by a plasmid, the phenotype (i.e. drug resistance, production of colicins, enterotoxins, restriction ard modification enzymes, production of antibiotics, and degradation of complex organic compounds) can be easily examined. Since such plasmid-specified functions can often 
be selected for. many genetic experiments are possible. Such studies have revealed information of genetic structure, function, replication and bacterial evolution. Plasmids are also powerful experimental tools for molecular biology. Genetic analysis of bacteria is often dependent on the transfer of genes between strains and plasmids can act as transfer agents. Certain plasmids can be transferred between different genera and are used to introduce DNA into novel hosts. The technique is of major importance in genetic engineering and cloning which allows large amounts of a specific gene regulated product to be purified.

\subsection{PLASMID ISOLATION}

The main problem to overcome in the preparation of plasmid DNA is its separation from chromosomal DNA, since the plasmid usually comprises no more than about $5 \%$ of the total DNA (Grinsted and Bennett, 1988). Plasmid DNA is usually isolated as a double-stranded covalently closed circular (CCC) molecule, which twists about itself in a form called a supercoil. A single break or 'nick' in one of the two strands causes the supercoil to convert to an open circular form, if the break occurs in both strands, a linear duplex structure will be formed. Most of the plasmid DNA isolated from bacterial cells is in the supercoiled configuration, which is the most compact form within the cell. Isolation of plasmid DNA can generally be accomplished by making use of the physical properties of the supercoiled DNA molecules and their 
small size in comparison with the bacterial chromosome (Hardy, 1986, 1987; Bimbaum and Doly, 1979; Eckhardt, 1978; Holmes and Quigley, 1981; Maniatis, 1982, 1989). As well, plasmid DNA often has a significantly different percentage of guanine-cytosine base pairs in comparison with the chromosome of the host strain. Based on the plasmid DNA form and $\mathrm{G}+\mathrm{C}$ content the sedimentation rate during ultracentrifugation varies, with the supercoiled form sedimenting more rapidly. Supercoiled molecules also show high sedimentation rates in liquids such as alkaline sucrose. The affinity for certain dyes such as ethidium bromide (EtBr) which intercalates within the DNA molecule, is less with the supercoiled form. Since binding of the dye lowers its density, supercoiled plasmid DNA assumes a different position in a cesium chloride $(\mathrm{CsCl})$ density gradient than chromosomal DNA following equilibrium centrifugation in $\mathrm{CsCl}-\mathrm{EtBr}$ gradients. To ensure the plasmid molecule remains in the CCC state and not linearalized by nicks caused by nucleases, lysis is performed in the presence of ethylene diaminetetra acetic acid (EDTA). EDTA chelates metal ions and so inactivates cation dependent nucleases. Cell extracts can then be saturated with cesium chloride and are then used to separate chromosomal DNA from plasmid DNA during ultracentrifugation (Broda, 1979; Freifelder, 1983; Hardy, 1986, 1987; Maniatis, 1989). The plasmid band can be visualized under a UV light source and removed from the gradient by inserting a syringe through the tube wall. Other methods of plasmid isolation exist and have the benefits of being fast and convenient in the sense that many samples can be tested in one day. These include in-well lysis (Eckhardt, 1978) where the bacteria are lysed by lysozyme followed by a SDS (sodium dodecyl sulphate) treatment within the wells of the agarose 
gel electrophoresis apparatus. When the gel is electrophoresed the chromosomal DNA hardly penetrates the gel allowing for the visualization of plasmid DNA. Other rapid methods of plasmid DNA isolation remove the chromosomal DNA first, either by a clearing spin or by selective precipitation (Holmes and Quigley, 1981; Birnbaum and Doly, 1979).

Plasmid DNA molecules of different sizes can also be isolated by electrophoresis on agarose gels, this method provides a way to isolate and size the plasmid DNA, as well as an opportunity to analyze the action of endonuclease and other enzymes on the plasmid DNA (Myers et al, 1976; Broda, 1979; Hintermann, et al, 1981; Schaffer and Sederoff, 1981; Maniatis, 1989; Freifelder, 1983; Hardy, 1986, 1987). Methods exist which also employ the use of ion-exchange, gel filtration chromatography or differential precipitation to separate plasmid and chromosomal DNA's. Most of these methods are not preferentially used; however, differential precipitation with polyethylene glycol can yield plasmid DNA of extremely high purity. Differential precipitation with polyethylene glycol differs from equilibrium centrifugation in $\mathrm{CsCl}$-ethidium bromide gradients in one respect; it does not efficiently separate nicked circular molecules in the closed form of plasmid DNA. A further method of plasmid isolation uses the different effect of high pH (12.0-12.5) on chromosomal and plasmid DNA. High pH denatures chromosomal DNA, but not CCC plasmids (Bimboim and Doly, 1979). If the pH is subsequently lowered and the salt concentration is kept high, chromosomal DNA precipitates, leaving C.C. plasmids in solution. Most of the high molecular weight cellular RNA also precipitates under these conditions as well as proteins if the detergent sodium dodecyl 
sulphate (SDS) is present (SDS solubilizes proteins). After centrifugation to remove the precipitate, the plasmid DNA is already sufficiently pure (after ethanol precipitation) for some kinds of experiments. It can however, be further purified by cesium chlorideethidium bromide centrifugation.

\subsection{PLASMID SIZING}

The sizing of plasmids can be accomplished by a number of methods. For example, electron microscopy by the Kleinschmidt method allows the measurement of the contour length based on a known standard. Alternatively, following electrophoresis in agarose of endonuclease restricted plasmid DNA with known standards, a standard curve of the distances travelled by these standard fragments as a function of the logarithm of their sizes can be constructed. The distance travelled by the sample frgaments can then be measured so that their size can be determined from the graph (the various bands can be added together to give the molecular weight). Densitometry can also be employed to differentiate between different fragments having similar sizes. Finally, sucrose gradients based on sedimentation coefficients ( $S$ values which relate to the molecular weight), with known standards, may also be used. 


\section{I.17 RESTRICTION MAPPING}

The physical restriction mapping of plasmids is accomplished using restriction endonucleases and gel electrophoresis. Restriction endonucleases are enzymes that recognize specific sequences of DNA and subsequently cut the phosphodiester backbone of the molecule. The electrophoretic patterns of enzymatic digests of the plasmid DNA are compared and a restriction fragment map is constructed. The most common method for deriving restriction maps is to use two different restriction enzymes. The procedure is to take three samples of a particular DNA species, treat each of two of these with a separate enzyme and one sample with both enzymes (a double digest), and then compare the three sets of fragments. Other methods involve the generation of partial fragments and the radiolabelling with ${ }^{32} \mathrm{P}$ or as will be seen later the use of hybridization with digoxigenin-labelled probes (DIG label).

\subsection{PLASMID COPY NUMBER}

The copy number of a plasmid is generally defined as the ratio of the number of moles of plasmid DNA to the number of mole equivalents of chromosomal DNA. The number of copies is used to categorize plasmids and to decide upon the replicon to use for gene cloning on the basis of dosage of the cloned gene required. Absolute copy 
number as will be seen is not always a useful value. Plasmids that contain 1-2 copies per chromosome are referred to as stringent compared to relaxed plasmids which are present in 15 or more copies per chromosome equivalent. However plasmid copy number will vary with the growth phase. As well, gene expression efficiency is not always directly related, therefore copy number may not always be used at face value. Physical methods are generally used to determine the proportion of a cell's DNA that is of plasmid origin. If the sizes of the plasmid and the chromosome are known the copy number can be calculated from this ratio. This approach requires that the plasmid and the chromosome DNA to be isolated with equal efficiency or at least known efficiencies (Broda, 1979). Plasmid specific RNA and DNA-DNA hybridization can also be used to determine plasmid copy number. Minimum estimates can be achieved by determining the proportion of total DNA that is in the CCC. This method however depends upon the efficient extraction of plasmid DNA as CCC molecules. Alternatively sucrose gradient centrifugation can be used to resolve both $\mathrm{CCC}$ and open circular plasmid DNA molecules from chromosomal DNA. Another commonly used technique is the method of Eckhardt (Eckhardt, 1978), to electrophoretically resolve total cell lysates on an agarose gel and then after staining with $\mathrm{EtBr}$, to use UV fluorescence spectrophotometry to determine the relative quantities of plasmid and chromosomal DNA. Estimation of copy number can also be achieved using $\mathrm{CsCl}-\mathrm{EtBr}$ density gradients and comparison with an internal standard (see Hardy, 1987 for complete descriptions). 


\subsection{METHANOGEN PLASMIDS}

Plasmids and a variety of DNA-containing phages have been characterized from methanogens. $M$. thermoautorophicum strain Marburg contains a $4.5 \mathrm{kbp}$, high copy number plasmid, pME2001 (Meille et al, 1983). It has been found to form multimers, up to a hexamer. An abundant 611 base transcript from this plasmid contains four ORFs, ranging in length from 234 bases to 90 bases, three of which are proceeded by potential ribosomal binding sites (RBS) (Meille et al, 1987). Derivatives of pME2001 have been constructed to replicate in E. coli, Bacillus subtilus, Staphylococcus aureus, and $S$. cerevisiae which have the potential to be used as shuttle vectors (Meille and Reeve, 1985). M. thermoautotrophicum strain deltaH contains a small amount of a plasmid that hybridizes to pME2001 DNA. A low copy number plasmid $8.7 \mathrm{~kb}$, pURB500 has been isolated and characterized from a new Methanococcus isolate (Wood et al, 1985). Plasmids have also been isolated from M. jannaschii (pURB800,64 kb; p(URB801,18 kb) and from a newly isolated related methanococcus, AG86 (pURB900, $20 \mathrm{~kb}$ ), from a deep sea hydrothermal vent (Zhao et al, 1988). Methanolobus vulcani contains a plasmid, pMP1, which integrates into the host chromosome and could be a prophage (Thomm et al, 1983; Wood et al, 1983; Wilharm et al., 1986). Methanoxarcina acerivorans, an acetotrophic methanogen, contains a plasmid, this plasmid has also been found as a multimer (Sowers and Gunsalus, 1988). Plasmid DNA was also found in three strains of Methanobacterium thermoformicicur 2 , a $10.5 \mathrm{~kb}$ plasmid, pFZ1 from strain Z-245 was characterized and determined to be cryptic, pFZ2 
(10.5 kb) and pFV1 (14 kb) were found in strains FTF and THF respectively (Nolling. 1991). A bacteriophage was isolated from a strain of Merhanosueta 'Methanothrix' (Roustan et al., 1986). Three other virus like particles are also known in methanogens PG, $50 \mathrm{~kb}$ found in M. smirhii (Zillig et al, 1988), a $35 \mathrm{~kb}$ particle in Methanocici'us sp. nov. (Zillig et al, 1988) and a $23 \mathrm{~kb}$ particle in Methanococcus voltue A.3 (Wood et al., 1989). This thesis will describe a new methanogen plasmid pDDK found in the organism Methanosaeta concilli strain GP6. 


\section{SECTION I}

\section{MATERIALS AND METHODS}

\subsection{ANAEROBIC CELL CULTURE AND GROWTH CONDITIONS}

Methanogenic bacteria are obligate anaerobes. Anaerobic culture techniques have boen developed for the growth of methanogens (Hungate, 1950; Bryant et al, 1968; Bryant and Robinson, 1968; Holdeman, 1972; Aranki, 1972; Wolfe, 1979; Balch et al, 1979; Hippe, 1984; Bernhardt et al, 1987). All procedures from the preparation of media, to the transfer of bacteria as well as all vessels and tubing used are free of oxygen, anaerobic (Plate 1). The gases used are passed through an oxygen scrubber. This is a column maintained at $350^{\circ} \mathrm{C}$ and filled with copper. Oxygen in the media is removed by persolating with $\mathrm{N}_{2}$ or being brought to a boil under an atmosphere of $80 \%$ $\mathrm{H}_{2} / 20 \% \mathrm{CO}_{2}$. Reducing agents such as cysteine and sulfide are added and the $\mathrm{pH}$ is adjusted to the desired level. The liquid media are delivered through tubing to flushed serum bottles or carboys and autoclaved. After cooling, it is again flushed with $80 \%$ $\mathrm{H}_{2} / 20 \% \mathrm{CO}_{2}$, stoppered and pressurized and volatile ingredients such as vitamins, fatty acids and methanol are added through flushed syringes from anaerobic stock solutions. Methods for solid media preparations are also available (Hungate, 1950; Edwards and McBride, 1975; Balch and Wolfe, 1976), as well as fermenter size preparations, but are 
not discussed here. The diversity of the methanogens is anparent in the different formulae for media tıat fulfill growth requirements. 


\section{PIATE 1: ANAEROBIC MEDIA SET UP}

Laboratory apparatus, diagram of the equipment and set up to work with anaerobic organisms. 1) $\mathrm{N}_{2}$ cylinder; 2) $20 \% \mathrm{CO}_{2} / 80 \% \mathrm{H}_{2}$ cylinder; 3) $\mathrm{O}_{2}$ scrubber (copper interior kept at $350^{\circ} \mathrm{C}$ ); 4) round bottom flask containing unreduced media; 5) this is brought to a boil over a bunsen burner, this entire process occurs while the round bottom flask is being flushed with nitrogen; 6) once boiling, reducing agents are added usually cysteine and/or sulphide, the $\mathrm{pH}$ is adjusted; 7) after transfer to flushed capped serum bottles; 8 ) the serum bottles containing reduced media are autoclaved, cooled and the vitamins and other volatiles are added; 8) all processes other tian autoclaving are performed in a fume hood, pressurized bottles are handled carefully and manipulations are performed behind plexiglass shields for safety. 


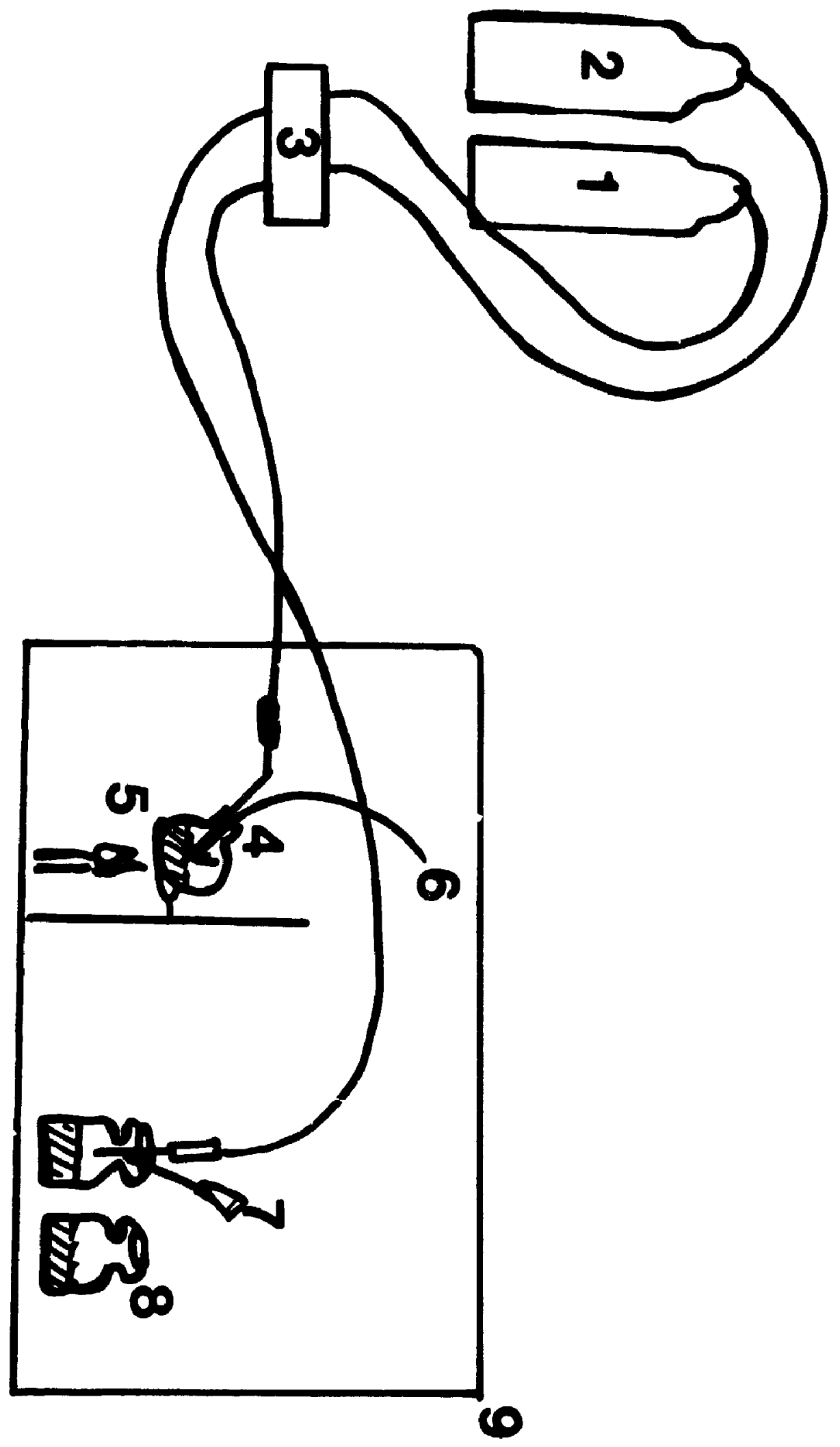




\subsection{CELL LYSIS: GENERAL}

The diversity in cell wall structure (Section 1.11) explains why methanogens vary greatly in the ease with which their cell walls can be disrupted. For example, certain methanococci lyse readily when suspended in solutions of low ionic strength, while mechanical methods such as multiple passages through a French pressure cell may be ineffeciive for others such as Methanobrevibacter smithii (pers. obs.).

For genetic studies, total genomic DNA must be extracted in a form where it is relatively unsheared or damaged by cellular nucleases. A number of enzymatic and chemical procedures have been developed for the release of unsheared high molecular weight DNA from eubacterial cells (Marmur, 1961; Sambrook et al., 1989). However, these procedures are often ineffective against the nonmurein containing methanogens (Keiner et al., 1987). The usefulness of the pseudomurein endopeptidase of Methanobacterium wolfei is limited to sensitive strains such as Methanobacterium thermoautotrophicum (Keiner et al., 1987), in w'sich there are no protecting wall layers exicrnal to the pseudomurein. In addition, the enzyme is not commercially available, and since it is $\mathrm{O}_{2}$ sensitive must be freed of contaminating endonucleases by anaerobic purification methods (Keiner et al., 1987). Spontaneous formation of osmoticallysensitive cell forms during growth have been reported for Methanobacterium bryantii (Jarrell et al., 1982) and Methanosarcina barkerii (Davis and Harris, 1985), but nuclease activity is likely to degrade the DNA during slow autolysis of the cells. Also, it has been found (pers. obs.) that procedures for DNA isolation from methanogens which 
involve the grinding of frozen cell pastes (Smucker and Pfister, 1975: Weil et al., 1988: Jarrell et al., 1991) or French pressure cell treatment of cells (Worrel et al., 1988), give low yields of DNA which is often sheared. Therefore a method was developed which was generally applicable to a wide range of methanogens, that produced DNA that could be restricted by restriction endonucleases and used laboratory reagents that were commonly available.

\section{BACTERIAL STRAINS}

The methanogens used in this study were obtained from the National Research Council of Canada culture collection and are listed in Table III pg. 10 of this paper. Methanobacterium thermoautotrophicum strain $\mathrm{H}$, Methanobacterium formicicum strains MF and G2R, Methanobacterium bryantii strains M.o.H and M.o.H.(i, Methanobacterium espanolii GP9, Methanospirillium hungatei GP1, Methanosuera concilli GP6, Methanobrevibacter smithii, Methanobrevibacter arhorrophilicus, Methanothermus fervidus, Methanosarcina mazei, Methanosarcina acetivorans, Methanosarcina barkeri, Methanococcus volfae and Methanococcus jannaschii. Methanobacterium espanolii GP9 and Methanosueta concilli GP6 were grown according to the procedure of Patel et al. (1990) respectively. Growth media and growth conditions for the other methanogens were as described by Sprott et al. (1990). 


\section{(:ONDITIONS OF CELL LYSIS}

All strains were grown anaerobically to the late exponential growth phase. Ten (10) $\mathrm{ml}$ samples in growth medium were collected by centrifugation. The samples were pelleted in a Sorval SS-34 rotor at 7,000 rpm for $10 \mathrm{~min}$. , one hali of the samples (four) were frozen as cell paste at $-20^{\circ} \mathrm{C}$ and thawed at $23^{\circ} \mathrm{C}$, the other half were used fresh.

All samples were gently resuspended in $10 \mathrm{ml}$ ABE buffer (ammonium bicarborate [Anachemia] $50 \mathrm{mM}$ pH 8.0; EDTA, ethylenediaminetetraacetic acid, disodium salt [Boeringe: Mannheim] $50 \mathrm{mM}$ ), and an O.D. 660 was taken maintaining the initial fixed volume of $10 \mathrm{ml}$ (Beckman spectrophotometer). Each of the four samples of fresh and frozen cells were treated differently to determine which chemicals were the contributing lysis agents and which steps in the following procedure series was necessary. Each sample was subjected to the following treatments: i) single treatments with one of pronase, sodium dodecyl sulphate (SDS) or dithiothreitol (DTT); ii) pronase treatment, followed by treatment with DTT and then by SDS; iii) pronase treatment, followed by SDS treatment; iv) pronase treatment, followed by DTT treatment; and, v) ABE only. Pronase (Boehringer Mannheim, predigested to inactivate nucleases (Sambrook et al., 1989) in $50 \mathrm{mM}$ Tris-HCL, pH 8, for $1 \mathrm{~h}$ at $37^{\circ} \mathrm{C}$ ) was used at a final concentration of $40 \mathrm{ug}^{\mathrm{ml}} \mathrm{ml}^{-1}$, for $1 \mathrm{~h}$ at $37^{\circ} \mathrm{C}$; DTT (Boeringer Mannheim) at a final concentration of $200 \mathrm{ug}$. $\mathrm{ml}^{-1}$, at $23^{\circ} \mathrm{C}$ for $15 \mathrm{~min}$; and, SDS (Sigma) at a final concentration of $200 \mathrm{ug}$. $\mathrm{ml}^{-1}$, at $55^{\circ} \mathrm{C}$ for $15 \mathrm{~min}$. After each treatment the optical density at $660 \mathrm{~nm}$ was recorded, and the percentage of cell lysis (\% lysis) determined. 
The percent lysis is defined by dividing the optical density at each relevant step by the initial optical density, multiplying by 100 and expressing the result as a percentage.

\section{DNA ISOLATION}

In order to recover the total genomic DNA, the cell debris was precipitated by the addition of potassium acetate to the lysed cells at a final concentration of $0.3 \mathrm{M}$, followed by incubation at $-20^{\circ} \mathrm{C}$ for $30 \mathrm{~min}$. The sample was centrifuged at $12100 \times$ $\mathrm{g}$ for $10 \mathrm{~min}$, and the supernatant was recovered. The DNA was precipitated by the addition of $1 / 5$ vol. of $10 \mathrm{M}$ ammonium acetate (IBI chemicals) and 2.5 vols. of absolute ethanol. DNA was recovered by centrifugation at $12100 \times \mathrm{g}$ for $10 \mathrm{~min}$ and resuspended typically in $500 \mathrm{ul}$ of $10 \mathrm{mM}$ Tris-HCL (Sigma), and $10 \mathrm{mM}$ FDTA, pH 8. DNA purity and concentration were determined, using UV absorbance. Concentration was determined by a calculation using the O.D. at UV $\lambda 280$;

O.D. $280 \times$ dilution factor $\times 50$ (for double stranded DNA) $=\mathrm{mg} / \mathrm{ml}$ or $\mathrm{ug} / \mathrm{ul}$ Purity is used to determine the possible contamination by protein and is determined by a ratio of the O.D. using UV at 260 to 280 . The ideal is a ratio of 1.9-2.0 for DNA.

\section{DNA MANIPULATION}

To determine the restriction of the DNA, the samples were digested in a $20 \mathrm{ul}$ vol. with the restriction endonuclease Bglli and Ps/l (Gibco/BRL) as directed by the manufacturer. After restriction digestion, immediately prior to gel electrophoresis, contaminating RNA was removed by the addition of 1 ul of KNase A (Boehringer 
Mannheim; $10 \mathrm{mg} \cdot \mathrm{ml}^{-1}$ in $300 \mathrm{mM}$ sodium acetate, $\mathrm{pH} 4.5$ ). The sample was incubated at 2.3"C for $2 \mathrm{~min}$, whereupon loading dye was added. Restricted and unrestricted DNA samples were subjected to electrophoresis and visualized as described by Sambrook et al. (1989).

\subsection{PLASMID SURVEY (SCREENING)}

Plasmid DNA, as was described in previous seitions is extrachromosomal DNA that can be used as vectors for gene transfer. The concept of the archaeaobacteria forming one of the three domains of living organisms (Woese et al., 1990) has generated considerable interest in identifying and characterizing archaeaobacterial extrachromosomal elements in order to study gene transfer in and develop transformation systems for these unique organisms (Nolling et al., 1991). Furthermore, detailed knowledge of these extrachromosomal elements contributes to understanding their evolution and their possible interaction with the chromosome of their hosts. Therefore the investigation of plasmid containing methanogenic species is of interest.

Total genomic DNA of all species (Table III) tested for lysis were screened for the presence of extrachromosomal DNA. After extraction of total genomic DNA (Meakin et al., 1991), $10 \mathrm{ul}$ samples were restricted as per manufacturers (Boeringer and Mannheim) instructions with Ps! I for $2 \mathrm{~h}$ at $37^{\circ} \mathrm{C}$. 10ul samples of each species were electrophoresed in TAE (Tris-acetate-EDTA; $40 \mathrm{mM}$ Tris, $20 \mathrm{mM}$ Acetate, $2 \mathrm{mM}$ EDTA, pH 7.8) containing $1.0 \%$ agarose (Sigma) for $12 \mathrm{~h}$ at $20 \mathrm{v}$ and $30 \mathrm{~mA}$. The agar 
gel was stained in a solution of $0.5 \mathrm{ug} / \mathrm{ml}$ ethidium bromide for $30 \mathrm{~min}$ and destained in distilled water for $30 \mathrm{~min}$. After stainıng, the gels were visualized and photographed under a UV light source. The photographs were analyzed for the presence of specific bands to indicate extrachromosomal DNA.

\subsection{PLASMID ISOLATION}

Following the screening of the methanogen species tested (Table III) the DNA suspected of being extrachromosomal DNA, occurring in Methanosuela concilii strain GP6 was isolated. The method of DNA isolation is not the usual method of CsC.1-1:Br ultracentrifugation as is commonly employed for isolating plasmid DNA. It was. however, found to be the only efficient method (see discussion). Total genomic DNA from $M$. concilii GP6 was electrophoretically resolved as described in section 2.3. The band suspected of being plasmid DNA was excised from the gel by cutting it out using a razor blade, under a UV lightsource and pooled. These bands containing the suspected plasmid DNA were then electro-eluted using a Bio-Rad Model 422 electro-eluter as per manufacturers instructions. The resulting DNA was again pooled in Tris EDTA buffer(usually gel slices from 5-20 wells of agarose gels), a 10 ul sample of this DNA was electrophoretically resolved as per above description to verify the purity of the band excised and the remainder stored at $4^{\circ}$ for further investigation. 


\subsection{PIAASMID PDDK CHARACTERIZATION}

In order to characterize the plasmid DNA, size, copy number, and restriction mapping were investigated. The size of the plasmid was determined by electrophoresis of Pst I and Ece RI digested (as per manufactures instructions) plasmid DNA against known standards of lambda Hind III (Boeringer Mannheim) and lkb standard (Boeringer Mannheim). The sizes of the restricted fragments of the DNA of interest were determined by relating gel mobility to the fragments of the standards. Sizes were determined by using a standard curve of the fragments in the standards (see section 1.16).

For copy number determination of the plasmid, now designated pDDK, several dilutions of total DNA isolated from strain GP6 were analyzed by agarose gel electrophoresis. By comparing the intensity of the plasmid band and the chromosomal DNA bands, the copy number can be determined with the assumption that the size of the chromosomal DNA of $M$. concilii GP6 is approximately $1.1 \times 10^{9} \mathrm{Da}$ (Nolling et al. 1991). $1 \mathrm{MDa}=1.500 \mathrm{bp}$

Restriction mapping is a useful tool in determining potential cloning sites, therefore, the mapping of restriction enzyme positions within the plasmid as initial characterization is necessary. Restriction fragment mapping was achieved by again a novel approach. First, single digestions of the plasmid DNA were electrophoretically resolved in an agarose gel with standards as described above, restriction enzymes used (as per manufactures instructions) were Bgl II, Hpa I, Eco RI and Pst II. Double 
restriction digests of the plasmid DNA (BgllI/Hpal; Bgll1/EcoRI; Bgll1/Pstl; Hpal/Pstl: Hpal/EcoRI; Pstl/EcoRI) were also electrophoretically resolved in an agarose gel under the same conditions and with the same standards. All gels were stained as described above and photographed with a ruler under UV light. After initial investigation of both sample types, single digestions and double digestions were run simultaneously on two agarose gels. (NOTE: the gels used for the Southern blots had a very low concentration of pDDK as the DIG is extremely sensitive, overloading of the gel leads to poorly defined bands. therefore, the gels used for the Southerns are not included here as no bands were visible), From initial single digests two bands were excised, a $6.9 \mathrm{~kb}$ band from the single Bgl II digestion and a $7.2 \mathrm{~kb}$ band from the Eco RI single digestion, electrophoretically resolved in low melting point agar (Sigma) and stored in sealed Eppendorf tubes at $4^{\circ}$. Southern blots of the agarose gels containing the double digested DNA were obtained (see Maniatis, 1989 and appendix I). The excised single bands from the low melting point agar gels were used as the probes for the Southern blots (Southern, 1975). The method of labelling used was chemiluminescence with digoxigenin (DI(j) (Amersham, as per manufactures instructions, latelling protocol appendix II). Following labelling the probes were hybridized to the filters obtained from the southern blotting and autoradiographed using the DIG antibody-chemiluminescence treatment (Appendix II). From the autoradiogram the position of the probe DNA's in the double restricted fragments could be determined therefore enabling the construction of th: restriction fragment map. 


\section{SECTION III}

\section{RESULTS AND DISCUSSION}

\subsection{CELL LYSIS}

The results of the various treatments with frozen-thawed cells are shown in Table IV. The complete process of pronase, DTT and SDS was necessary to obtain maximum lysis for several of the strains (Meakin et al., 1991)(Table 4). In the case of Methunorhermus fervidus, where \% lysis was less than for most of the other strains tested, repeated freeze/thawing did not substantially increase lysis. Furthermore, in certain methanogens (e.g., Methanobacterium strain G2R and Methanobacterium bryantii M.o.H.G), the pretreatment of frozen-thawed cells with SDS was less effective at $35^{\circ} \mathrm{C}$ compared to $55^{\circ} \mathrm{C}$, which led to the use of $55^{\circ} \mathrm{C}$ routinely. Treatment with SDS alone lysed cells well in the cases of Methanobacterium bryantii strain M.o.H, Merhanospirillium hungatei strains GP1 and JF1, Methanosarcina barkerii and Merhamosuera concilii. In several cases, freeze/thawing of cells in ABE was sufficient for lysis. Not surprisingly, two of these strains were Methanococcus species, which lyse quite readily in the absence of salt and osmotically stabilizing solutions (e.g. sucrose)(Jones et al., 1983). Methanosarcina mazei lysed readily, whereas Methanosaeta concilii and Methanosarcina acetivorans exhibited partial lysis. Methanosarcina arerivoruns is of marine origin, and known to lyse in the absence of stabilizing salts (Sowers et al., 1983). Freeze-thawing sensitized the cells of several methanogens to the 
combination of pronase, DTT, and SDS treatments (Plate 2, Table 4). This effect was less pronounced for the four remaining methanogens listed in Table III but not shown in Plate 2.

Pronase greatly influenced the lysis of Methanobrevibacter smirhii, as well as the lysis of several other methanogens (Plate 3, Table 4). Pronase action was limited to cells which had been frozen and thawed, suggesting that freeze-thaw damage had exposed sites to enzyme attack. This data is supportive of a previous report showing that pronase contains a proteolytic enzyme capable of inducing lysis of Methanobacterium formicicum (Bush, 1985), and specifically strain Gol of Methanosarcina harkerii (Jussofie, 1986). Although the maximum lysis of each strain varied from 51-99\%, enough DNA was extracted from $0.25 \mathrm{~g}$ of each sample to perform several restriction analyses. In most cases, the genomic DNA was amenable to enzyme restriction analyses with Psil (Plate 4 a.), however, with Methan thermus fervidus [mol G + C 33\% (Stetter et al., 1981)] and Methanobacterium smithii [molG + C 32\% (Balch et al., 1979)], Bglll (Plate 4 b.) was more effertive than Pstl. Several of these DNA's tested in this experiment have been restricted with other restriction enzymes or ligated with vector plasmids in the construction of genomic libraries (pers. com. Dr.J.Nash).

Recently Jarrel et. al. 1991, published a method of lysis for a range of methanogen species. This included liquid nitrogen freezing and grinding, although this method has been reported to produce DNA which could be restricted by endonucleases, personal observations have found this to be a time consuming method with variable results, often shearing the DNA. 


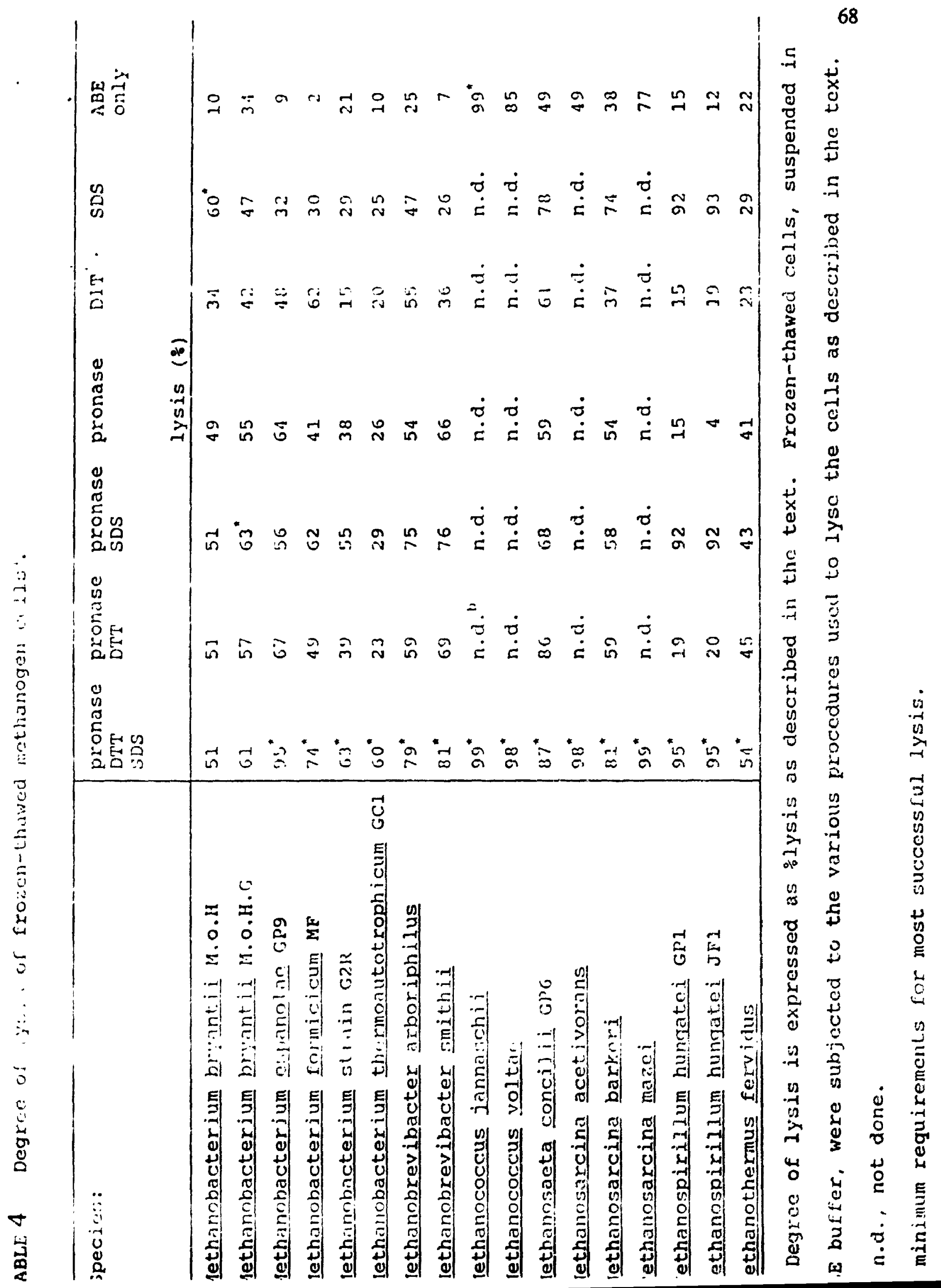




\section{PLATE 2: LYSIS OF METHANOGEN CELLS FRESH VS. FROZEN}

Lysis of methanogen cells comparing fresh (riosed bars) and frozen-thawed (hatched bars) cells. The cells were lysed by treatment with pronase, DTT and SDS as described in the text, to both cells that had been frozen and cells that were used fresh. 


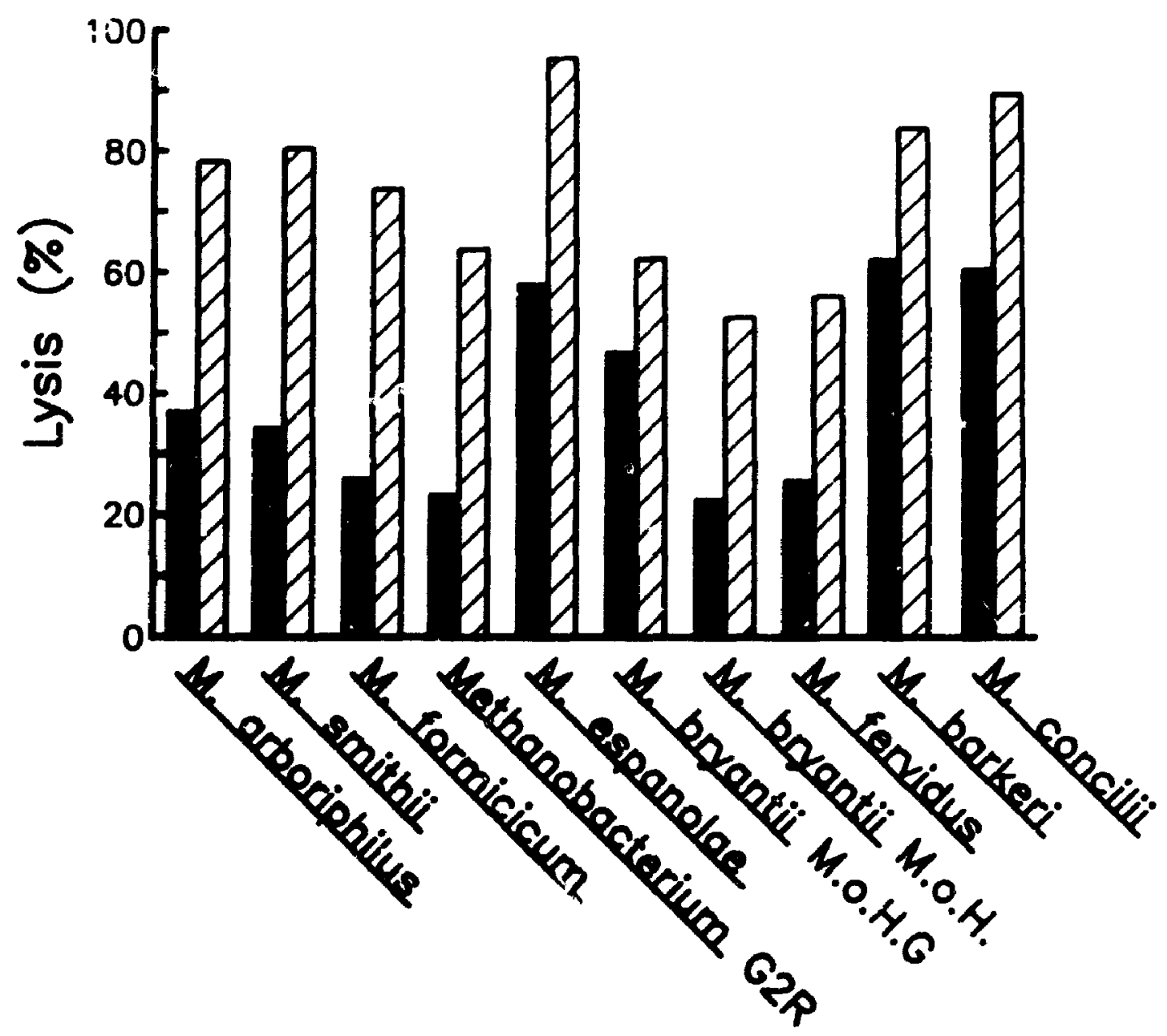


PLATE 3: PRONASE-INDUCED LYSIS (\% difference)

The effect of pronase on the lysis of fresh (closed bars) or frozen-thawed (hatched bars) cells of several methanogens. Fresh and frozen-thawed cells of each methanogen were divided into two aliquots. One aliquot was treated with pronase, while the other served as a control lacking pronase. All cell suspensions were treated with DTT and SDS, as described in the text, and lysis measured. Results are expressed as the difference in \% lysis caused by the presence of pronase. 


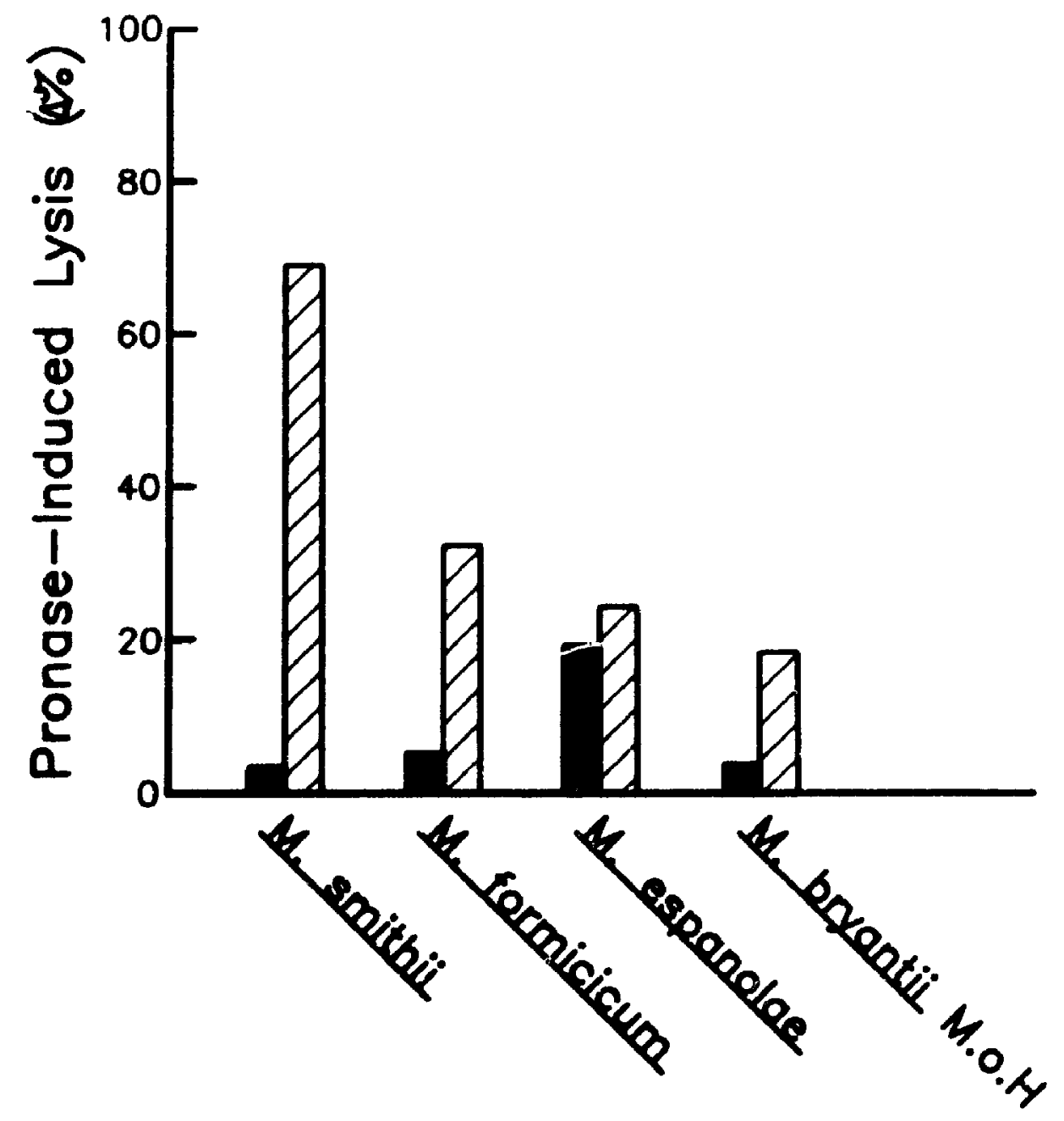




\section{PLATE 4: GEL ELECTROPHORESIS OF EXTRACTED DNA FROM METHANOGENS}

Gel electrophoresis of extracted DNA form methanogens. DNA samples were electrophoretically resolved through $\mathbf{0 . 8 \%}$ agarose gels in Tris-borate buffer at $70 \mathrm{~V}$ for $3.5 \mathrm{~h}$ (panel A), or $1.0 \%$ agarose in Tris-acetate buffer at $30 \mathrm{~V}$ for $16 \mathrm{~h}$ (Panel B), and stained with ethidium bromide. Numbers to the left represent DNA sizes (in bp) of the DNA standard. Starting with lane 2, the first sample in each pair is uncut DNA, while the second sample is digested DNA. Panel A (Pstl-restricted DNA): lane 1, DNA standard (1kb ladder, Gibco/BRL); lanes 2-3, M. espanolue GP9; lanes 4-5, M. smirhii; lanes 6-7, M. concilii GP6 (NOTE: the presence of pDDK in this picture after restriction with the endonuclease Pstl could be the result of partial cutting) ; lanes 8-9. $M$. fervidus; lanes 10-11, $M$. hungatei $\mathrm{JF} 1$; lanes 12-13, $M$. voltae; lanes 14-15, $M$. acetivorans. Panel B (Bglll-restricted DNA): lane 1, I kb ladder; lanes 2-3, M. fervidus; lanes 4-5, M. smithii; lane 6, phage lambda DNA digested with HindIII. 

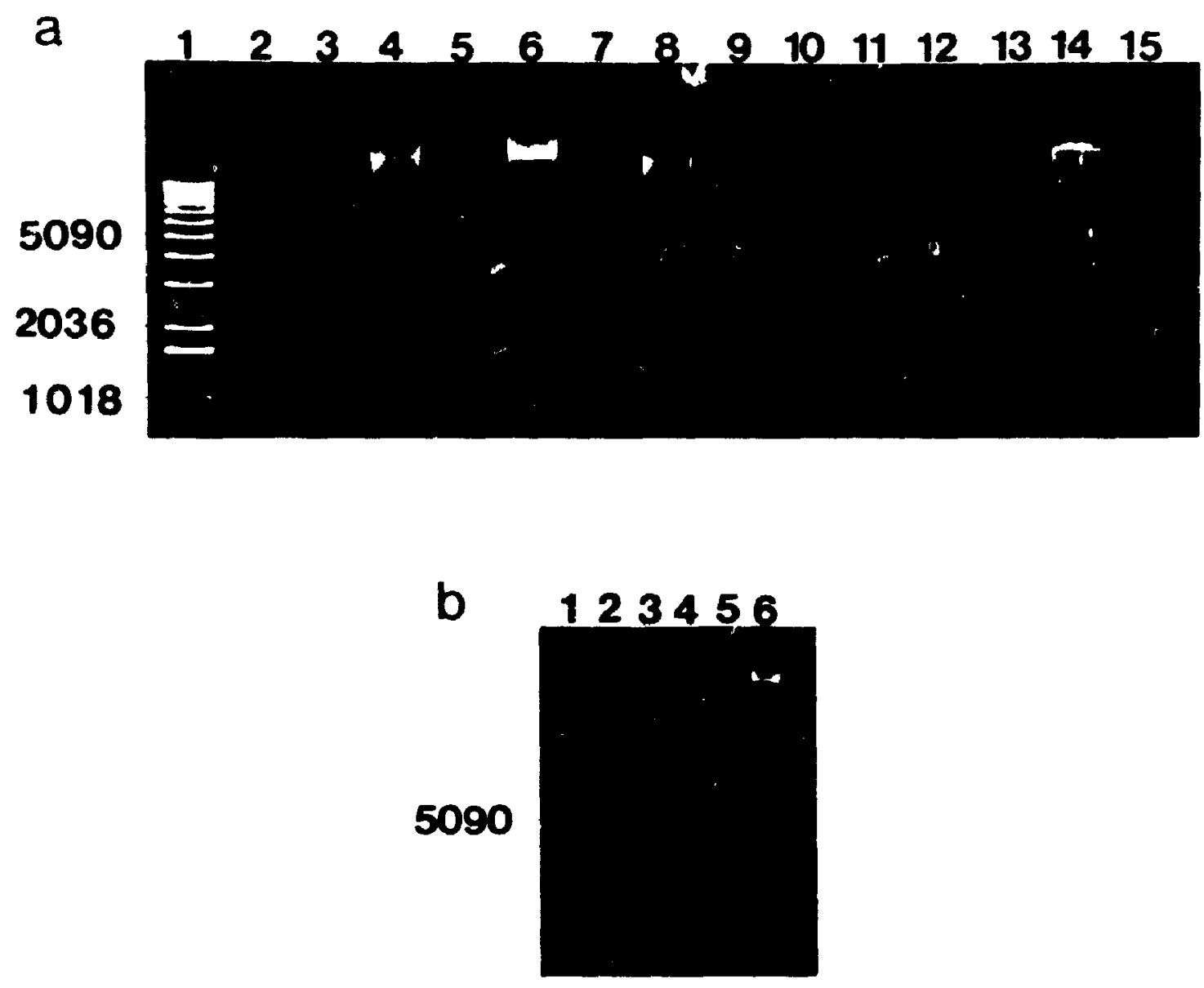
Martin and Savage (1988) noted that the DNA, in crude lysates of the obligate anaerobe Roseburia cercicola, degraded upon exposure to air. Although this possibility was not critically evaluated in the case of methanogen DNA, the inclusion of DTT to aid in cell lysis may have had an additional role in the protection of the DNA. As a precaution, DTT may be included during the initial pronase digestion.

Presented here is a simple method to readily isolate restrictable genomic DNA from a wide range of species of methanogenic bacteria. The method involves harvesting mid-exponential phase cells, freeze-thawing them, and lysing them in ammonium bicarbonate-EDTA buffer, $\mathrm{pH} 8$, by sequential treatments with pronase $\left(37^{\circ}\right.$ for $\mathrm{lh}$ ). DTT $\left(23^{\circ} \mathrm{C}\right.$ for $\left.15 \mathrm{~min}\right)$ and $\mathrm{SDS}\left(55^{\circ} \mathrm{C}\right.$ for $\left.15 \mathrm{~min}\right)$. After removal of all the cell debris and SDS precipitation with potassium acetate, followed by centrifugation, DNA is recovered by precipitation with ethanol. Although not all the steps of this procedure are necessary (e.g. freeze-thawing or pronase treatment) for complete lysis of all the strains tested, their inclusion does not handicap the successful isolation of genomic IDNA. Furthermore, the addition of pronase probably acts to degrade any contaminating DNases which would decrease the recoverable yield of DNA. Purity and concentrations were determined for all species, $M$. concilii, ior example average a $260: 280$ ratio of 1.9 , and a concentration of $4.360 \mathrm{ug} / \mathrm{ul}$. 


\subsection{SUSPECTED METHANOGEN PLASMIDS AND A NOVEL METHANOGEN PLASMID}

The plasmid screening showed a extrachromosomal band in Methanosueta concilii (jP6, named pDDK (see Plate 4 a. lane 7). Other species which indicated the possible presence of plasmids were Methanobacterium espanolae GP9, Methanospirillium hungatei $\mathrm{JF}: \mathrm{l}$ and Methumosarcina mazei. The data for the suspected extrachromosomal elements in the four species listed, is not shown as this data was taken from the analysis of a number of preparations and subsequent agarose gel resolutions. The evidence was the presence of bands other than the chromosomal DNA band, further analysis would be necessary to confirm these findings. At this time it was decided to concentrate on one plasmid and pDDK from Methanosaeta concilii was chosen. This plasmid was chosen as it was an organism isolated in Dr. G. Patel's laboratory at N.R.C., it is also the only pure culture of an acetoclastic, mesophilic methanogen that can use only acetate as a carbon source.

\subsection{ISOLATION AND PURIFICATION OF pDDK}

Once pDDK was identified from the screening as a possible extrachromosomal element, it was purified from the chromosomal DNA. The first method attempted was CsC-EtBr ultracentrifugation; after several unsuccessful attempts to separate the plasmid 
from the chromosomal DNA other methods were explored. The reison for the unsuccessful separation by $\mathrm{CsCl}-\mathrm{EtBr}$ ultracentrifugation remains unknown. Perhaps the plasmid form u'as nicked and bacame linear, such that it no longer behaved as a circular molecule. This altered mobility during centrifugation could result in its co-migration with the chromosomal DNA. It was at this time known "rom the screening procedure that the plasmid pDDK separated in gel electrophoresis and migrated very slowly forming the band above the chromosomal DNA. This indicated that the plasinid may be in a multiple state such as a trimer, tetramer or more or that the plasmid was very large $>20.0 \mathrm{~kb}$. If this was the case it would be difficult to sefarate by ultracentrifingation. Migration of DNA using electrophoresis is size dependent up to approximately $20.0 \mathrm{~kb}$., above this size DNA molecules tend to run with comm.a mobility regardless of size. Pulse-field electrophoresis which is commonly used for large molecule separation (Serwer, 1990) was explored using a Hoeffer PC 750 puise controller. Th s method separated the plasmid pDDK from the chromosomal DN. 1 in the same manner as traditional gel electrophoresis. It , as therefore used only to separate the plasmid band for excision as was traditional gel electrophoresis. It became apparent that a $m+$ thod to purify the plasmid was to electrophoretically resolve total DNA preparations from Methanosaeta concilii GP6 (see Plate 5), excise the plasmid band and elute it from the agarose. This was performed as described in the metho is resulting in a reasonably pure solution of pDDK (see Plate 6). The purity and concentration of pDDK were calculated as described in the methods and found to have a $260: 28$ r ratio of $-1.6-1.9$ and a concentration of $0.53 \mathrm{ug} / \mathrm{ul}-1.43 \mathrm{~kg} / \mathrm{ul}$ (depending on prepaiation). 
PLATE 5: TOTAL CHROMOSOMAL ELECTROPHORESIS OF GP6

$1.0 \%$ agarose gels in $0.5 \%$ TAE buffer: $30 \mathrm{v}, 25 \mathrm{~mA}$ overnight. Lane $1.1 \mathrm{~kb}$ standard; Lanes 2-14. 30 ul total GP6 DNA; Lanes 15. Lambda Hindlll. This gel is shown to describe the method of first electrophoretically resolving total Merhanosaeara concilii ${ }^{n}$ DNA, then excising the plasmid band and eluting the plasmid DNA from these gel sices. 


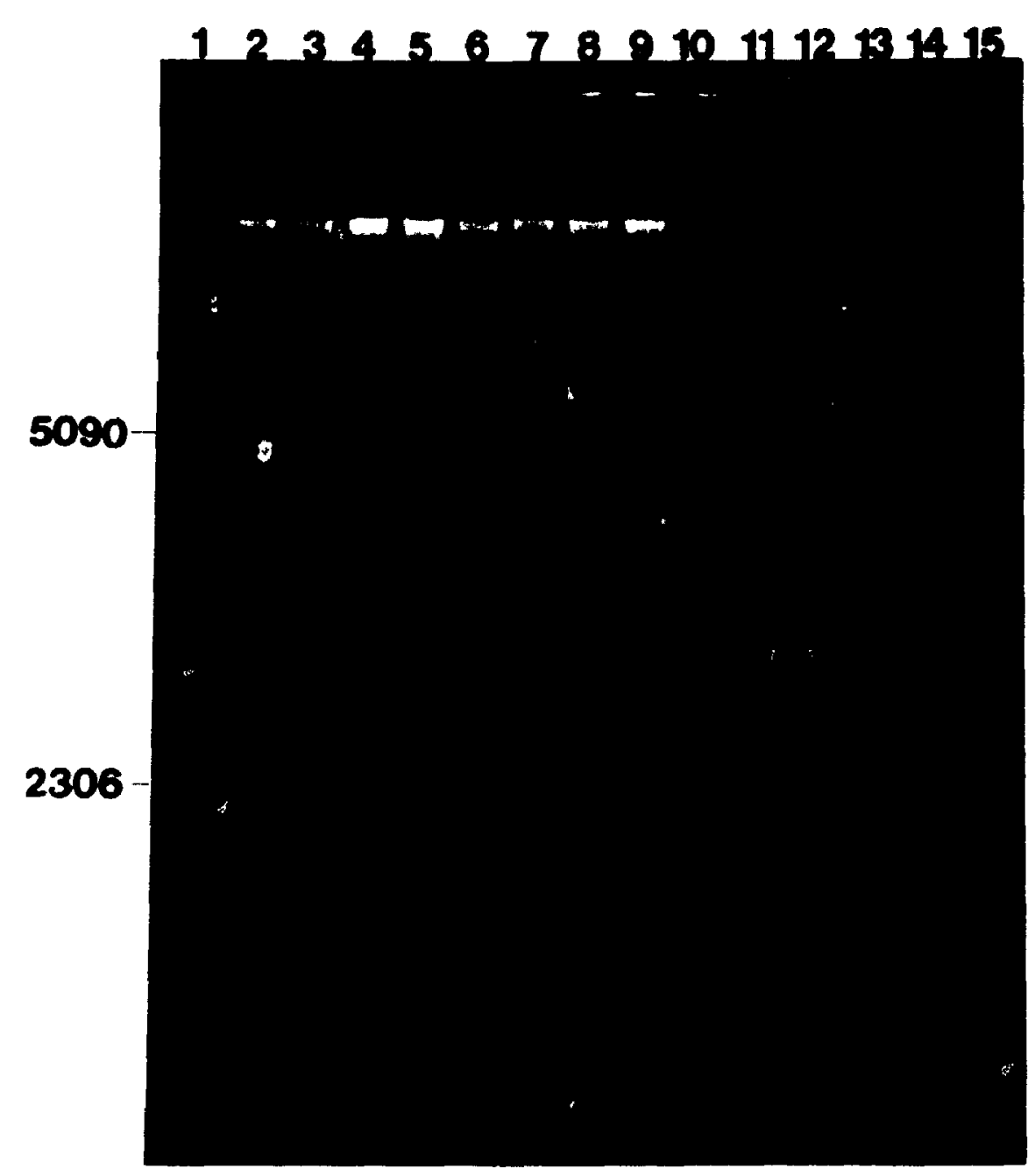




\section{PIATE 6: ELUTED pDDK SAMPLE}

$1.0 \%$ agarose gei in $0.5 \%$ TAE; $30 \mathrm{~mA}, 25 \mathrm{~V}$ overnight, Lane $1.1 \mathrm{~kb}$ standard; Lane 2. eluted pDDK (10 ul). The standard in this picture is inappropriate for the size of the plasmid band, it was included only as a standard to ensure the gel conditions were correct; this picture is included to show only that pDDK was purified from the chromosomal DNA and the preparation after elution contained pDDK. 


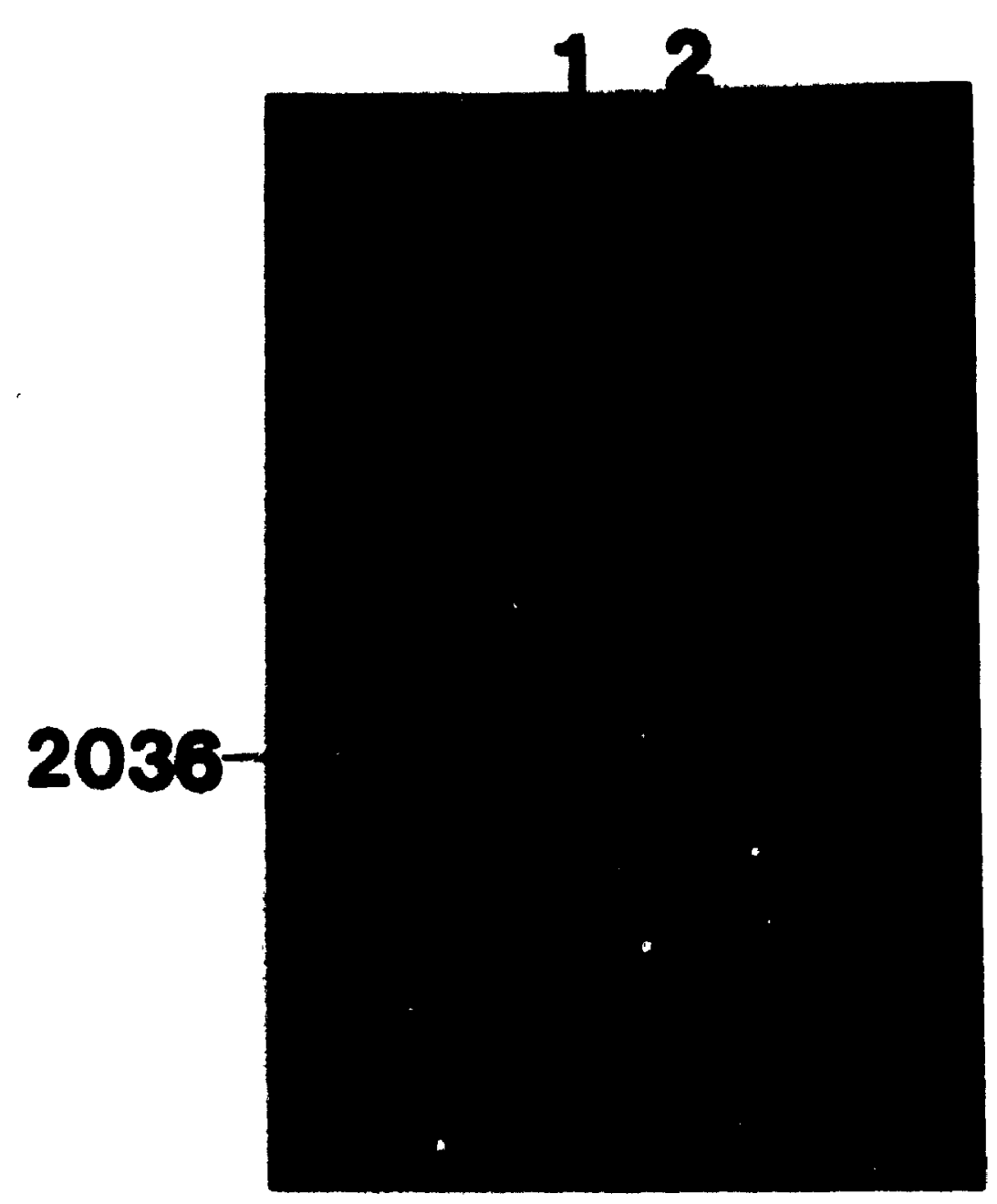




\subsection{CHARACTERIZATION OF pDDK}

The characterization of pDDK involved determining the size, restriction map, form and copy number of the plasmid. The size was determined to be $11.0 \mathrm{~kb}$. This determination was from the addition of restriction fragments (see Plate 7 ), compared to standard fragments. The form was determined to be circular. Evidence supporting this claim was from the hybridization studies undertaken to complete the restriction map. The pa!tern of the restriction digest fragments (undigested, single digests and double digests) after probing on the autoradiograms revealed that the molecule was circular. The restriction map was constructed from data collected as described in the methods section (see autoradiograms, Plate 8 i., ii. and Table 5) and is shown in (Plate 9). The copy number was determined to be $1 / 5$ of the chromosomal DNA; at $11.0 \mathrm{~kb}=$ approximaetly 10 copies per cell.

As mentioned in section 1.18, plasmids have been found in a number of methanogens. They are variable in size, ranging from $65 \mathrm{~kb}$ to $4.5 \mathrm{~kb}$, pDDK at $11 \mathrm{~kb}$ is within this range. The copy numbers of methanogen plasmids also vary and as of yet all are cryptic. as no plasmid functional genes have been elucidated to date. 
TABLE V FRAGMENT SIZES USED TO CALCULATE RESTRICTION MAP

i. SINGLE DIGESTS

BglII HpaI PstI EcoRI

$\begin{array}{llll}6.900 & 6.100 & 2.950 & 7.600 \\ 1.800 & 4.500 & 2.680 & 3.300 \\ 1.635 & 2.500 & 1.880 & 1.300\end{array}$

ii. DOUBLE DIGESTS

BglII/Hpal BgllI/EcoRI Bglli/Pstl Hpal/Pstl Hpall/EcoRI Pstl/EcoRI
6.600
3.050
1.800
2.900
16.500
2.650
3.750
2.560
5.450
2.600
4.600
0.080
3.400
1.850
1.850
3.250
1.720

iii. SOUTHERN BLOTS HYBRIDIZED WITH DIG LABELLED PROBES

A. Bgll PROBE (6.90 kb)

BglII/HpaI BglII/EcoRI BglII/PsII
4.072
3.900
2.205
3.059
2.980
1.900

B. ECORI PROBE (7.20 kb)

Bgll1/EcoRI Hpal/EcoRI PstI/EcoRI
4.072
4.361
3.059
2.100
3.990
2.027
2.027 

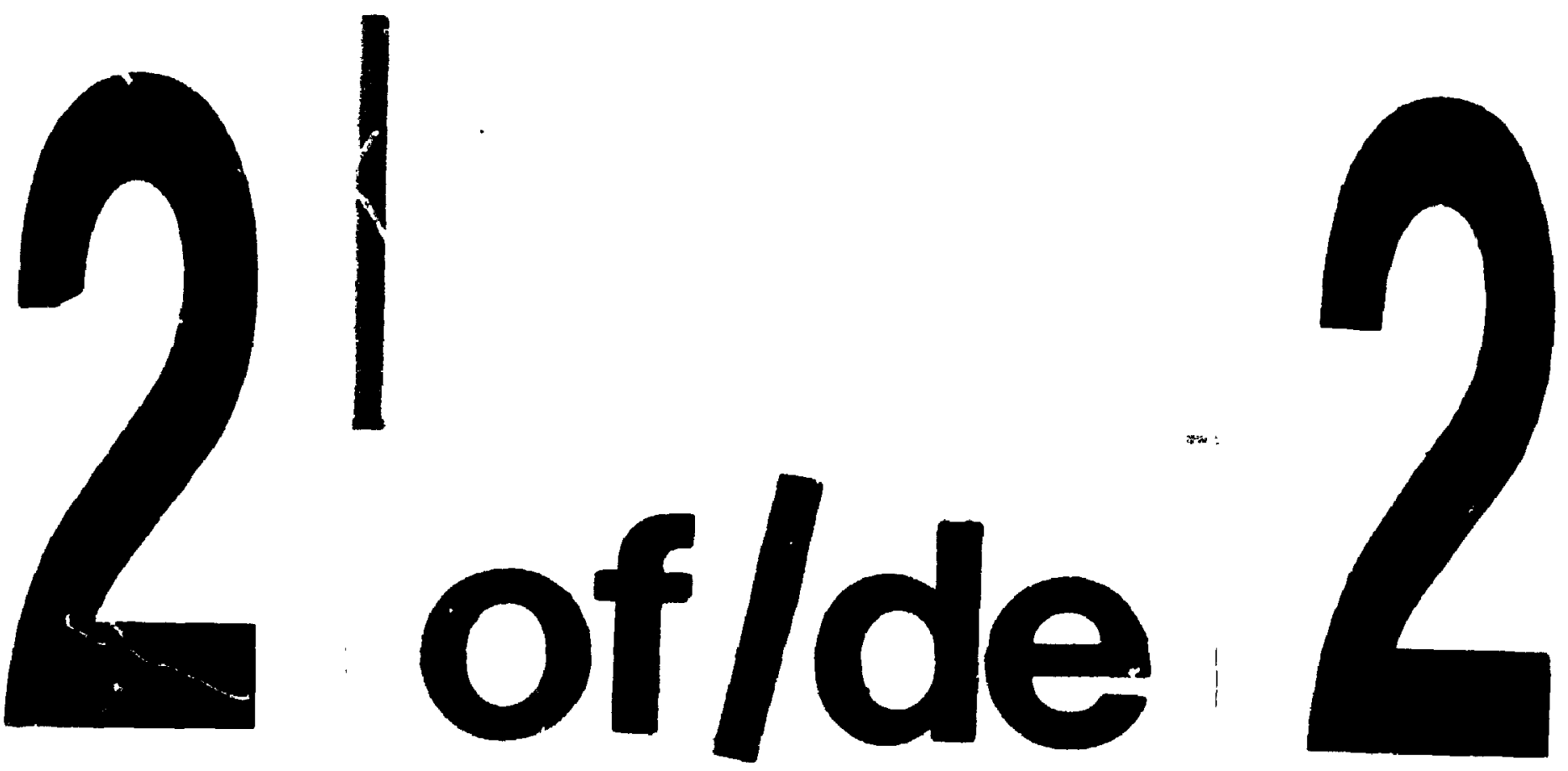

PM-1 31/2" $\times$ 4" PHOTOGRAPHIC MICAOCOPY TAP.CET NAS 101na ANSI/ISO \#2 EOUIVALENT

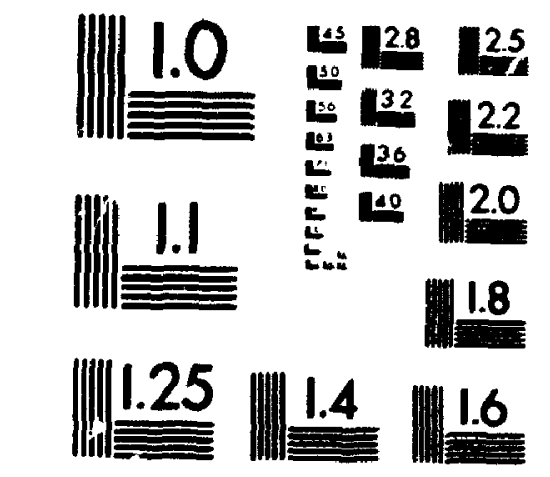

PRECISIONEM RESOLUTION TARGETS

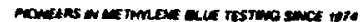

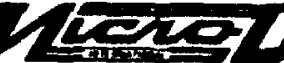


84

\section{PLATE 7: RESTRICTION FRAGMENT ANALYSIS OF pDDK}

Restriction digestion was performed as described in the methods section. 1.(0\% agarose gel, in $0.5 \%$ TAE buffer; $30 \mathrm{~mA}, 25 \mathrm{~V}$ overnight. I anes 1: $1 \mathrm{~kb}$ standard, Lane 2-11: 10ul of pDDK used, Lane 2: Bglll, Lane 3: hpal, Lane 4: Pstll, Lane 5: EcoRI, Lane 6: Bglll/ㅁal, Lane 7: Bglll/EcoRI, Lane 8: Bglll/Pstl, Lane 9: Hpal/ Psll.

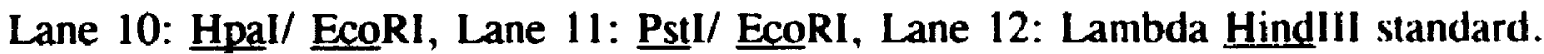




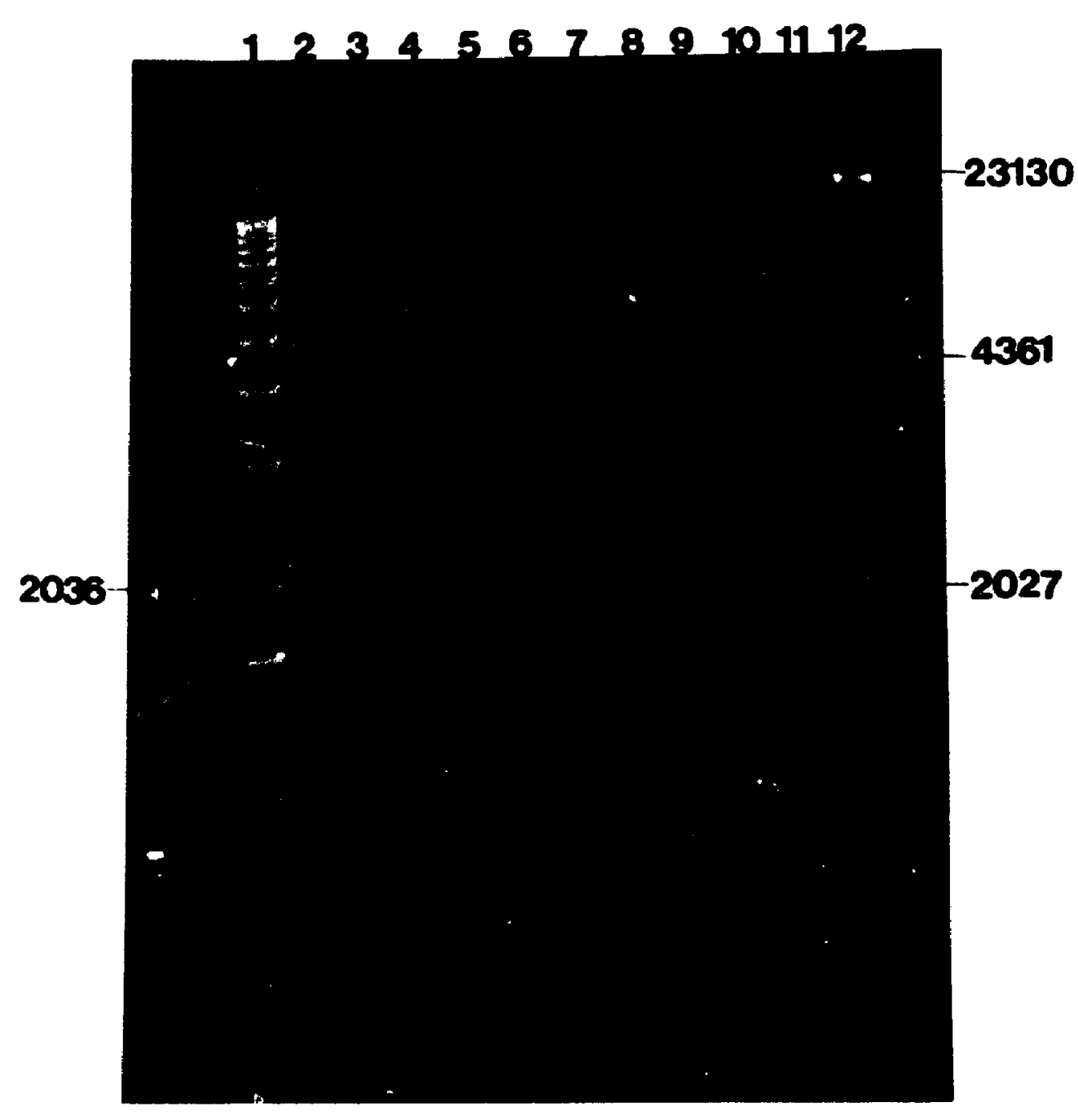


PLATE 8 i. AUTORADIOGRAMS OF DIG-PROBED SOUTHERN BLOTS USING BglII PROBE

Undigested pDDK, and double restriction digested pDDK electrophoretically resolved as per method section, southern blotted and probed with Dig labelled excised band a) Bglll probe, Lane 1. pDDK uncut; Lane 2. pDDK Bglll: Lane 3. pDDK BGLII/Hpal; Larie 4. pDDK BglII/EcoRI; Lane 5. pDDK BgllI/PstI. 


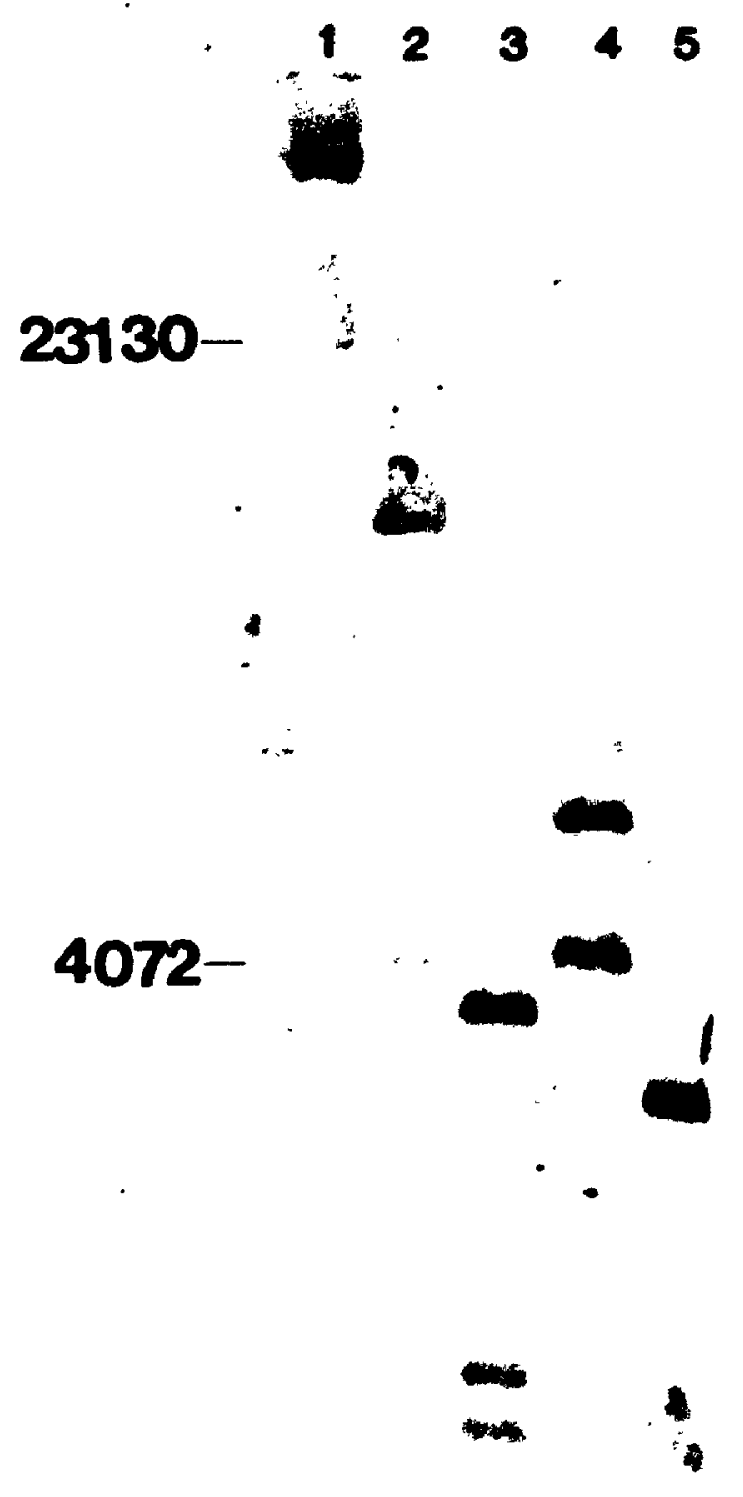


PLATE 8 ii. AUTORADIOGRAMS OF DIG-PROBED SOUTHERN BLOTS USING ECURI PROBE

Undigested pDDK, and double restriction digested pDDK electrophoretically resolved as per methods section, Southern Blotted and probed with Dig labelled excised band. b) EcoRI probe, Lane 1. pDDK uncut; Lane 2. pDDK EcoRI; Lane 3. pDDK EcoRI/BglII; Lane 4. EcoRI/Hpal; Lane 5. EcoRI/PstI. 


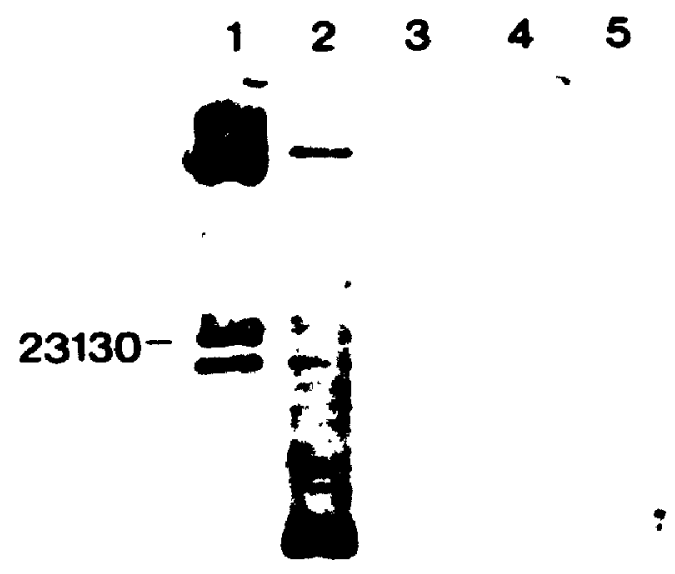

4072-
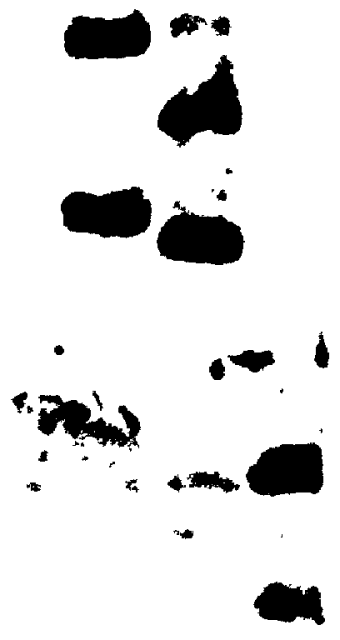

1 
90

PLATE 9: $\quad$ RESTRICTION FRAGMENT MAP OF PDDK

Constructed restriction fragment map of $\mathrm{pDDK}$. 


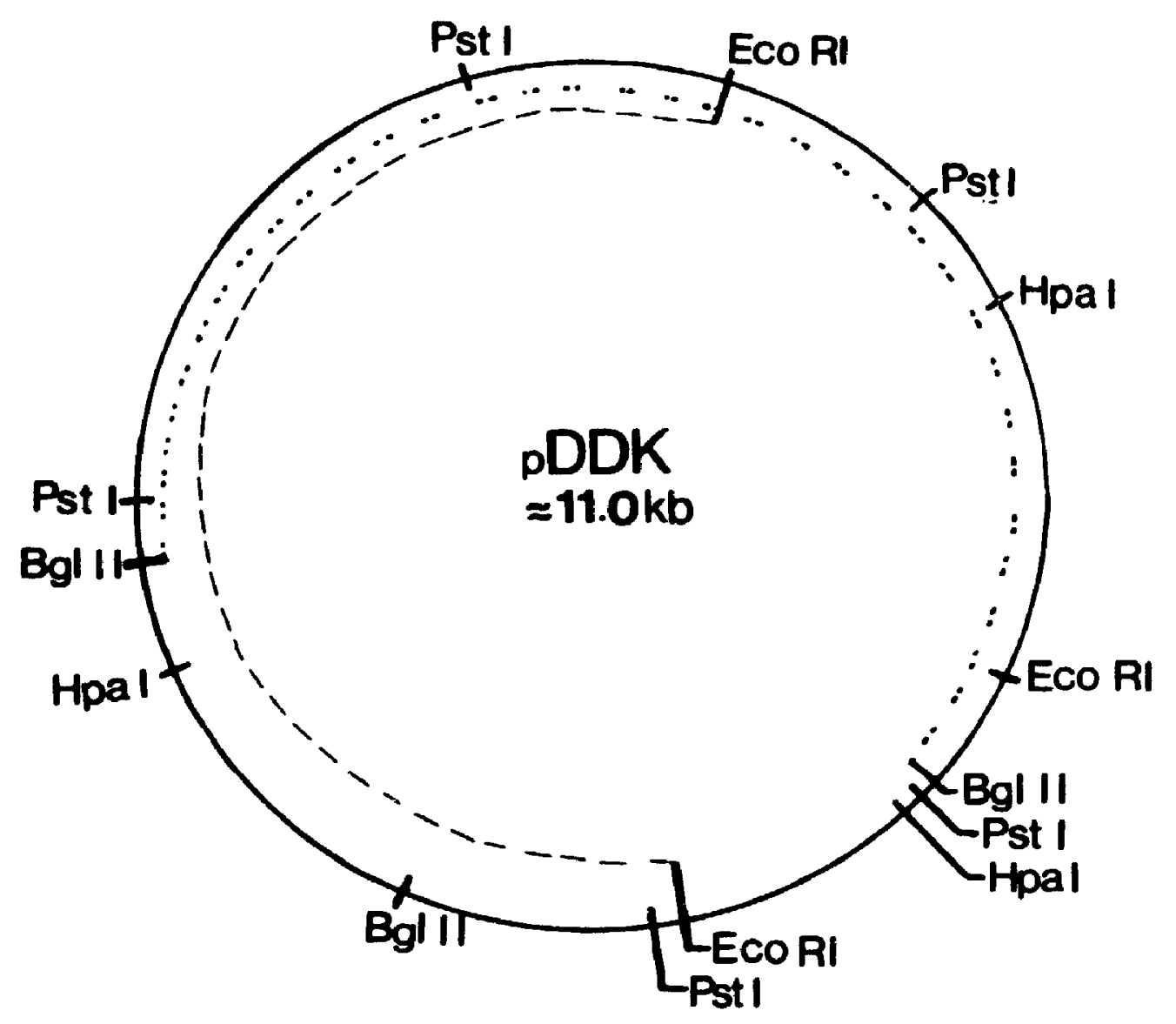

\section{.... Bgl II probe - EcoRI probe}




\section{SECTION IV}

\section{CONCLUSIONS AND FUTURE PROSPECTS}

Methanogens and the process of methanogenesis have revealed novel biological and physiological properties. Many of these novelties are specializations for a unique form of energy metabolism, a phenomenon common to the archaeobacteria (Jones et al., 1987). The diversity of biochemical and phylogenetic characteristics exhibited in the methanogens, once unravelled will reveal information of great interest to evolutionary and molecular biologists as well as the bacterial physiologists. The general areas of phylogeny, coenzyme, metal and membrane biochemistry have already proven this to be the case. The future prospects in molecular biology and genetic engineering are quickly emerging. It is the merging of all the scientific disciplines and their discoveries which may lead to utilization of these organisms for environmental, industrial and medical advancements.

The purpose of this thesis was to investigate the molecular biology of these organisms with the goal to increase the information available on methods of lysis and the presence of plasmids. This information will add to the increasing knowledge becoming available.

The method of lysis in this paper allows for a large number of species with variable cell ultrastructures to be readily lysed. This is important in screening processes for plasmids and extraction of chromsomal DNA for further genetic studies. The 
characterization of the plasmid pDDK is only the beginning of possible future genetic studies on the host organism Methanosaeta concilii. More importantly the protocols presented here may be used to study other undiscovered methanogen plasmids. This as well as the advances in solid media culturing may lead to the development of a genetic exchange system by the identification of selectable traits. The subsequent problem of successful transfer and the identification of transfer of DNA from the donor strain to the recipient strain may be aided by the discovery of a plasmid capable of acting as a vector.

There remains much work to be done on all aspects of these unique organisms. Future work from this thesis would involve the sequencing of the plasmid pDDK, once sequenced the possible function of genes carried by the plasmid may be ellucidated by comparing the sequence to a bank of known genes from methanogens or eubacteria. As well as hybridization studies of it to the host chromosomal DNA may reveal information of the plasmid function and evolution. Further hybridization studies of pDDK to other known plasmids may also be of interest in determining the origins of the plasmid as well may reveal information in possible function. Other work would involve the curing of plasmid pDDK. This could be accomplished by successive transfers of the culture under conditions stress; using temperature, $\mathrm{pH}$, or metabolic requirements variations. As this plasmid is now available cloning experiments to determine if pDDK could be used as a vector may be attempted. Another interesting series of experiments would be to determine if the acetoclstic ability to utilize acetate as a carbon source is conferred on the plasmid. To examine this question other acetoclastic organisms sucil as M. barkeri, $M$. mazei. $M$. acetivorans could be examined. It is known that $M$. acetivorans contains 
a plasmid pC2A, as well $M$. mazei is suspected of carrying a plasmid, these along with $M$. barkeri should be examined indepth to determine if infact the plasmid is conferring the ability to use acetate. 


\section{APPENDIX 1}

\section{SOUTHERN BLOT PROTOCOL}

1) After electrophoresis of DNA samples, the gel is stained and destained as per methods and photographed.

2) Denature the gel in $0.5 \mathrm{M} \mathrm{NaOH}$ and $1.5 \mathrm{M} \mathrm{NaCl}$ for $30.0 \mathrm{~min}$. shaking at room teinperature.

3) Neutralize gel in 1.0 M NH 4 Acetate and $0.02 \mathrm{M} \mathrm{NaOH}$ for $30.0 \mathrm{~min}$. shaking at room temperature.

4) Cut 2 pieces of Hybond Nylon filter (Manufaturer) and 6 pieces Whatman filter paper (Manufact) the same size as the gel.

5) Place the three pieces of the Whatman filter paper soaked in the neutralizing solution on a flat hard surface, being careful to role out any air bubbles with a pipette. Place the gel DNA side up on the filter paper. On top of the gel place the Hybond filter (use gloves to avoid fingerases) and the remaining soaked Whatman filter paper. Place a dry sponge on top of the Whatman and a hard flat surface above this (a plastic or glass plate works well). place weights on the plastic plate and allow transfer to proceed overnight ( 2 hrs. is sufficient if necessary).

6) Separate the gel and the filter and rinse the filter in 2X SSC to remove bits of agarose. Expose the Hybond filter to UV light for $5 \mathrm{~min}$. to fix.

7) The filter is now ready for hybridization. (see appendix II, for protocol) 


\section{APPENDIX II}

(pers. comm. J. Nash)

\section{Eybridization with DIGOXIGENIN-labelled probes (Part 1).}

1. Labelling of the probe DNA

a. Solutions:

DIG 10x dNTP labelling mixture.

. $\mathrm{mM}$ dATP

$1 \mathrm{mM}$ dCTP

$1 \mathrm{mM}$ dGTP

$0.65 \mathrm{mM}$ dTTP

$0.35 \mathrm{mM}$ DIG-dUTP

$\mathrm{dH}_{2} \mathrm{O}$
$25 \mu 1$ of $10 \mathrm{mM}$ dATP

$2.5 \mu 1$ of $10 \mathrm{mM}$ dCTP

$2.5 \mu l$ of $10 \mathrm{mM}$ dGTP

$1.75 \mu l$ of $10 \mathrm{mM}$ dTTP

$8.75 \mu \mathrm{l}$ of $1 \mathrm{mM}$ DIG-dUTP (Boehringer Mannheim)

$7 \mu l$

- $\quad$ React $210 x$ buffer from BRI

- Random primers (from Amersham or New England Biolabs, or Boehringer Mannheim or Gibco-BRL - they're all much the same).

- Probe DNA (50 to $1000 \mathrm{ng}$ is optimum, but $10 \mathrm{ng}$ should do).

b. Reaction:

- Denature the probe DNA in a 10 to $32.5 \mu$ l volume (made up with $\mathrm{dH}_{2} \mathrm{O}$ ) by boiling for $5 \mathrm{~min}$ at $100^{\circ} \mathrm{C}$, followed by $5 \mathrm{~min}$ on ice.

Set up the following reaction tube:

React 2 10x

denatured DNA

DIG 10x dNTP labelling mixture random primers $\mathrm{dH}_{2} \mathrm{O}$ Klenow polymerase
$5 \mu 1$

10 to $32.5 \mu \mathrm{l}$

$5 \mu 1$

$5 \mu 1$ to $50 \mu l$ final volume (incl. Klenow)

\section{$2.5 \mu 1$}

Incubate at $37^{\circ} \mathrm{C}$ for at least $3 \mathrm{hr}$, but $16 \mathrm{hr}$ is optimum. If incubation is for an extended period, add $100 \mu \mathrm{l}$ of light mineral oil to the tube. Extended incubations generate/synthesize more probe fragments. 
Remove the mineral oil by spotting the whole sample onto clean Parafilm. The oil will disperse leaving the aqueous sample as a drop on the Parafilm. Transfer the sample to a clean Eppendorf tube.

Add:

$4 \mu 1$ $12.6 \mu 1$ $375 \mu 1$

$0.5 \mathrm{M}$ EDTA, pH 8

$4 \mathrm{M} \mathrm{LiCl}$

cold absolute ethanol.

Precipitate at $-70^{\circ} \mathrm{C}$ for $30 \mathrm{~min}$ (usuall. EtOH precipitations are done at room temp. This is different.). Spin at $4^{\circ} \mathrm{C}$ for $15 \mathrm{~min}$. Wash with $70 \%$ ethanol and absolute etharol. Resuspend in 50 to $100 \mu 1$ TE buffer.

Probe concentration can be estimated by spotting on ethidium bromide plates.

Use the probe at 20 to $100 \mathrm{ng} / \mathrm{ml}$ hybridization solution. Denature the probe by boiling at $100^{\circ} \mathrm{C}$ and chilling on ice before use.

The probe can be reused over and over again. If it is in a large volume of hybridization solution, increase the boil and chill times \pm 215 wir. Store the probe frozen between uses.

2. Eilter hybridization and autoradiography.

Avoid scratching the filters or drying them out This leads to BAD background problems! Volumes of pre-hyb., hyb., and wash solutions are given per $100 \mathrm{~cm}^{2}$ filter $(10 \mathrm{~cm} \times 10 \mathrm{~cm})$. Adjust your volumes proportionally.

- Remove the debris from the filter(s) (if it's a colony/phage lift) by incubation with 5XSSC, $0.1 \%$ SDS at $65^{\circ} \mathrm{C}$, with shaking. Remove extra debris using a gloved finger.

An hour before the pre-hybridization, make the hybridization solution. Make approx $24 \mathrm{ml}$ per $100 \mathrm{~cm}^{2}$ filter - a circular Petri plate filter is approx $50 \mathrm{~cm}^{2}$. 
Hybridization solution (per $100 \mathrm{ml}$ ):

$5 \mathrm{xSC}$

$0.1 \%$ N-lauroyl sarcosine, $\mathrm{Na}$ salt (NLS)

$0.2 \%$ SDS

1\% Boehringer Mannheim blocking agent

$\mathrm{dH}_{2} \mathrm{O}$ or $10 \mathrm{ml}$ of blocking agent $10 x$ (see recipe below)

$25 \mathrm{ml} \mathrm{20x} \mathrm{SSC}$

$2 \mathrm{ml} 5 \%$ NLS

$2 \mathrm{ml} 10 \%$ SDS

$2 \mathrm{~g}$ of powder

If powdered blocking agent is used, stir at $50^{\circ}$ to $70^{\circ}$ for $1 \mathrm{hr}$. If blocking agent $10 \mathrm{x}$ is used instead, incubate at $50^{\circ}$ to $70^{\circ}$ for $30 \mathrm{~min}$.

- $\quad$ Prehybridize in hybridization solution, with shaking, at $68^{\circ} \mathrm{C}$ for $>1 \mathrm{hr}$. Use $20 \mathrm{ml}$ hyb. sol. / $100 \mathrm{~cm}^{2}$ filter. Pour off pre-hyb. sol. immediately before adding hyb. sol. PLUS probe.

- $\quad$ Hybridize in hyb. sol. PLUS 10 to $100 \mathrm{mg} / \mathrm{ml}$ denatured probe at $68^{\circ} \mathrm{C}$ for $6 \mathrm{hr}$ to overnight (preferred), with gentle shaking. Use $2.5 \mathrm{ml}$ hyb. sol. PLUS probe per 100 $\mathrm{cm}^{2}$ filter.

- After hybridization, transfer the filters to a glass dish containing $2 x S S C, 0.1 \%$ SDS. Store the probe for reuse.

The washes are:

Two washes in $2 x$ SSC, $0.1 \%$ SDS at room temp. for $10 \mathrm{~min}$.

One wash in $1 \times \mathrm{SSC}, 0.1 \% \mathrm{SDS}$ at $68^{\circ} \mathrm{C}$ for $10 \mathrm{~min}$

Use $50 \mathrm{ml}$ wash sol. per $100 \mathrm{~cm}^{2}$ filter. Wash with shaking.

The filters are now ready for the antibody treatment. 
3. Antibody treatment.

- Wash filters briefly ( 2 to $5 \mathrm{~min}$ ) in buffer $1 \mathrm{M}$ at room temperature with shaking. Use $50 \mathrm{ml}$ per $100 \mathrm{~cm}^{2}$ filter.

Buffer 1M: $100 \mathrm{mM}$ maleic acid

$150 \mathrm{mM} \mathrm{NaCl}, \mathrm{pH} 7.5$. Usually made as a $5 x$ concentrate.

- Incubate filters in buffer $2 \mathrm{M}$ at room temp, with gentle shaking for $>30 \mathrm{~min}$. Use $100 \mathrm{ml}$ per $100 \mathrm{~cm}^{2}$ filter.

Buffer 2M: $10 \%$ blocking agent $10 \mathrm{x}$ in buffer $1 \mathrm{M}$, i.e. for $100 \mathrm{ml}$ of buffer $2 \mathrm{M}$, use $10 \mathrm{ml}$ blocking agent $10 \mathrm{x}+20 \mathrm{ml}$ buffer $1 \mathrm{M}$ $5 x+70 \mathrm{ml} \mathrm{dH_{2 }} \mathrm{O}$.

Blocking agent $10 x$ :

Add $50 \mathrm{~g}$ blocking agent powder (Cat. 1096 176, Boehringer Mannheim) to a 500 $\mathrm{ml}$ measuring cylinder. Add $100 \mathrm{ml}$ buffer $2 \mathrm{M}$, and $\mathrm{dH}_{2} \mathrm{O}$ to $500 \mathrm{ml}$. Stir at $60^{\circ} \mathrm{C}$ until the powder has all dissolved. Autoclave the solution, and dispense aseptically into $40 \mathrm{ml}$ lots. Store at $4^{\circ} \mathrm{C}$.

- Incubate the filters in buffer 2M PLUS antibody. Antibody (Anti-digoxigenin-Ap, FAB fragments Cat. 1093274, Boehringer Mannkim) should be diluted at $75 \mathrm{mU} / \mathrm{ml}$ -i.e. diluted 1: 10000 . Incubate filters with gentle shaking for $>\mathbf{3 0} \mathrm{min}$ at rooin temp. Use $20 \mathrm{ml}$ per $100 \mathrm{~cm}^{2}$ filter.

- Wash the filters twice for $15 \mathrm{~min}$ at room temp, with gentle shaking, in buffer 1M. Use $100 \mathrm{ml}$ per $100 \mathrm{~cm}^{2}$ filter.

- Equilbrate filters for $>2 \mathrm{~min}$ in buffer 3 . Use $20 \mathrm{ml}$ per $100 \mathrm{~cm}^{2}$ filter.

Buffer 3: $100 \mathrm{mM}$ Tris, $\mathrm{pH} 9.5$

$100 \mathrm{mM} \mathrm{NaCl}$

$50 \mathrm{mM} \mathrm{MgCl}$ 
4. Chemiluminescence treatment.

Use either Lumiphos 530 or AMPPD, there's no real difference, results-wise.

Lumiphos 530 protocol:

Put 2 to $3 \mathrm{ml}$ Lumpihos in a large watchglass. Wet filter (probe side down) in the solution. Seal in heatseal bags (don't use ziplock, it inactivates the Lumiphos). Incubate at $37^{\circ}$ for $15 \mathrm{~min}$. Expose to film for 15 to $60 \mathrm{~min}$. The light signal is active for approx $24 \mathrm{hr}$, so re-exposure is possible.

Store the used Lumiphos in a scintillation vial in the dark. it is reyasble.

AMPPD protocol:

AMPPD comes at $10 \mathrm{mg} / \mathrm{ml}^{2}(3.5 \mathrm{mM})$. Dilute it 1:100 in buffer 3 . Incubate filters in AMPPD for a few min. Seal the filters in a heatseal bag. Incubate at $37^{\circ}$ for 5 to $15 \mathrm{~min}$. Expose to film for 15 to $60 \mathrm{~min}$. AMPPD is also reusable. Store it at $4^{\circ}$ in the dark. The signal is also active for approx. $24 \mathrm{hr}$. 


\title{
REFERENCES
}

\begin{abstract}
Allmansberger, R., C. Bollschweiler, U. Konheiser, B. Muller, E. Muth, G. Pasti and A. Klein. 1986. Arrangement and expression of methyl CoM reductase genes in Methanocccus voltae. Syst. Appl. Microbiol. 7, 13-17.
\end{abstract}

Arkani, A. and R. Freter. 1972. Use of anaerobic glove boxes for the cultivation of strictly anaerobic bacteria. Am. J. Clin. Nutri. 25, 1329-1334.

Balch, W.E. and R.S. Wolfe. 1976. New approach to the cultivation of methanogenic bacteria: 2-mercaptoethanesulfonic acid (HS-CoM)-dependent growth of Methanobacterium ruminantium in a pressurized atmosphere. Appl. Environ. Microbiol. 32, $781-791$.

Balch, W.E., G.E. Fox, L.J. Magrum, C.R. Woese and R.S. Wolfe. 1979. Methanogens: reevaluation of a unique biological group. Microbiol. Rev. 43, 260-296.

Bernhardt, G., R. Jaenicke and H.D. Ludemann. 1987. High pressure equipment for growing methanogenic microorganisms on gaseous substrates at high temperature. Appl. Environ. Microbiol. 53, 1876-1879. 
Bertani, L. and G. Baresi. 1984. Study of methanogens by genetic techniques. SERI/STR-231-2291, Solar Energy Research Institute.

Bertani, G. and L. Baresi. 1987. Genetic transiormation in the methanogen Methanococcus voltae PS. J. Bacteriol. 168: 2730-2738.

Beveridge, T.J., M. Stewart, R.J. Doyle, and G.D. Sprott. 1980. Unusual stability of the Methanospirillum hungatei sheath. J. Bacteriol. 162, 728-737.

Beveridge, T.J., G.B. Patel, B.J. Harris and G.D. Sprott. 1986 a. The ultrastructure of Methanothrix concilii, a mesophilic acetoclastic methanogen. Can J. Microbiol. 32, 703-710.

Beveridge, T.J., B.J. Harris, G.B. Patel and G.D. Sprott. 1986 b. Cell division and filament splitting in Methanothrix concilii. Can. J. Microbiol. 32, 779-786.

Beveridge, T.J., B. Harris and G.D. Sprott. 1987. Septation and filament splitting in Methanospirillium hungatei. Can. J. Microbiol. 33, 725-732.

Bhatnagar, L., J.G. Zeikus and J.P. Aubert. 1986. Purification and characterization of glutamine synthetase from the archaebacterium Methanobacterium ivanovi. J. Bacteriol. 165, 638-643. 
Bhatnagar, L., M.K. Jain, J.G. Zeikus and J.P. Aubert. 1986. Isolation of auxotrophic mutants in support of ammonia assimilation via glutamine synthetase in Metanobacterium ivanovi. Arch. Microbiol. 144, 350-354.

Blaut, M., V. Muller and G. Gottschalk. 1990. Energetics of Methanogens. In: The Bacteria vol, XII. Bacterial Energetics Ed. T.A. Krulwich. Academic Press, Inc. New York, N.Y. Pg. 505-537.

Birnbaum, H.C. and J. Doly. 1979. A rapid alkaline extraction procedure for screening recombinant plasmid DNA, Nucleic Acids Res. 7, 1513-1523.

Bock, A. and O. Kandler. 1985. Antibiotic sensitivity of archaebacteria. In: The Bacteria vol.8 Archaebacteria. eds. C.R. Woese and R.S. Wolfe. Academic Press, Inc., New York. pg. 525-544.

Bollschweilder, C. and A. Klein. 1982. Polypeptide synthesis in Escherichia coli directed by cloned Methanobrevibacter arboriphilus DNA. Zentralbl. Bakteriol. Parasitenkd. Infektionskr. hyg. Abt. 1 Orig. Reihe C. 3, 101-109.

Bokranz, M. and A. Klein. 1987. Nucleotide sequence of methyl coenzyme $M$ reductase gene cluster from Mehanosarcina barkeri. Nucleic Acids Res. 15, 4350-4351. 
Bokranz, M. G. Baumner, R. Allmansberger, D. Ankel-Fuchs and A. Klein. 1988. Cloning and characterization of the methyl coenzyme $M$ reductase genes from Methanobacterium thermoautotrophicum. J. Bacteriol. 170(2), 568-577.

Bowen, T.L. and W.B. Whitman. 1987. Incorporation of exogenous purines and pyrimidines by Methanococcus voltae and isolation of analog-resistant mutants. Appl. Environ. Microbiol. 53(8), 1822-1826.

Broda, P. 1979. Plasmids. W.H. Freeman. Oxford. pp.1-22.

Brown, J.W. and C. Daniels and J. Reeve. 1989. Gene structure, organization, and expression in archaebacteria. CRC in Microbiology, 10(4), 287-337.

Bryant, M.P. and I.M. Robinson. 1961. An improved nonselective culture medium for rumen bacteria and its use in determining diurnal variation in of numbers of bacteria in the rumen. J. Dairy Sci. 44, 1446-1456.

Bryant, M.P., B.C. McBride and R.S. Wolfe. 1968. Hydrogen-oxidizing methane bacteria. I. cultivation and methanogenesis. J. Bacteriol. 95, 1118-1123.

Bush, J.W. 1985. Enzymatic lysis of the pseudomurein containing methanogen Methanobacterium formicicum. J. Bacteriol.163: 27-36. 
Charlebois, R., W.L. Lam, S. Cline and W.F. Desittle. 1987. Characterization of pHV2 from Halobacterium volcanii and its use in demonstrating transformation of an archaebacterium. Proc. Natl. Acad. Sci. U.S.A. 84, 8530-8534.

Cline, S.W. and W.F. Doolittle. 1987. Efficient transfection of the archaebacterium Halobacterium halobium. J. Bacteriol. 169, 1341-1344.

Cline, S.W., W.L. Lam, R. Charlebois, L.C. Schalkwyk and W.F. Doolittle. 1989. Transformatio. methods for halophilic archaebacteria. Can. J. Microbiol. 35, 148152.

Cram, D.S., B.A. Sherf, R.T. Libby, P.J. Mattaliano, K.L. Ramachandran and J.N. Reeve. 1987. Structure and expression of the genes, merBDGCA, which encode the subunits of componebt $\mathbf{C}$ of methyl coenzyme $\mathbf{M}$ reductase in Methanococcus vannielii. Proc. Natl. Acad. Sci. U.S.A. 84, 3992-3996.

Daniels, L. 1984. Biological methanogenesis: physiological and practical aspects. Trends in Biotechnol. 2, 91-98.

Daniels, L., N. Balchiet and K. Harmon. (1985). Widespread distribution of a 5deazaflavin in actinomyces and related bacteria. Syst. Appl. Microbiol. 65, 12-17. 
Danson, M.J. 1989. Central metabolism of the archaebacteria; an overview. Can. J. Microbiol. 35, 58-64.

Davis, R.P. and J.E. Harris. 1985. Spontaneous protoplast formation of Merhanosarcina barkeri. J. Gen. Microbiol. 131, 1481-1486.

Dennis, P.P. 1986. Molecular biology of archaebacteria. J. Bacteriol. 168, 471-478.

Eckhardt, T. 1978. A rapid method for the identification of plasmid desoxyribonucleic acid in bacteria. Plasmid, 1, 584-588.

Elhardt, D. and A. Bock. 1982. An in vitro polypeptide synthesizing system from methanogenic bacteria: sensitivity to antibiotics. Mol. Gen. Genet. 188, 128-134.

Fox, G.E., E. Stackebrant, R.B. Hespell, J. Gibson, J. Maniloff, T.A. Dyer, R.S. Wolfe, W.E. Balch, R. Tanner, L. Magrum, L.B. Zallen, R. Blakemore, R. Gupta, L. Bonen, B.J. Lewis, D.A. Stahl, K.r. Luehrsen, K.N. Chen, C.R. Woese. 1980. The phylogeny of prokaryotes. Science $209,457-463$.

Frea, J.I. 1982. Methanogenesis: Its role in the carbon cycle. In: Microbial Chemoautotrophy. eds. W.R. Strohl and O.H. Tuovinen. Ohio State U. Press, Columbus. pg. 228-253. 
Freifelder, D. 1983. Molecular Biology A Comprehensive Introduction to Prokaryotes and Eukaryotes. Jones and Bartlett Pub. Inc. Boston. pps. 701-807.

Gernhardt, P., O. Possot, M. Foglino, L. Sibold and A. Klein. 1990. Construction of an integration vector for use in the archaebacterium Methanococcus voltae and expression of an eubacterial gene. Mol. Gen. Genet. 221, 273-279.

Gottschalk, G. and M. Blaut. 1990. Generation of proton and sodium motive forces in methanogenic bacteria. Biochim. Biophys. Acta, 1018, 263-266.

Grinsted J. and M. Bennett. 1988. Preparation and electrophoresis of plasmid DNA. In: Methods in Microbiology, vol. 21 Plasmid Technology. Eds. J. Grinsted and P.M. Bennett. Academic Press, London. pg. 143-154.

Haas, E.S., L.A. Hook and J.N. Reeve. 1986. Antibiotic resistance caused by permeability changes of the archaebicterium Methanococcus vannielii. FEMS Microbiol. Lett. 33, 185-188.

Hackett, N.R. and S. DasSarma. 1989. Characterization of the small endogeneous plasmid of Halobacterium strain SB3 and its use in transformation of $\boldsymbol{H}$. halobium. Can. J. Microbiol. 35, 86-91. 
Hamilton P.L. and J.N. Reeve. 1985. Sequence divergence of an archaebacterial gene cloned from a mesophilic and a thermophilic methanogen. J. Mol. Evol. 22, 351360.

Hamilton, P.L. and J.N. Reeve. 1985. Cloning and expression of archaebacterial DNA from methanogens in Escherichia coli. In: Microbial Chemoautotrophy. pg. 291308.

Hamilton, P.L. and J.N. Reeve. 1985. Structure of genes and an insertion element in the methane prodicing archaebacterium Methanobrevibacter smirhii. Mol. Gen. Genet. 200, 47-59.

Hamilton, P.L. and J.N. Reeve. 1986. Molecular biology of archaebacteria. In: Microbiology pg. 337-348. (ed.) L. Leive. American Society for Microbiology, Washington, D.C.

Hardy, K.J (ed). 1987. Plasmids a pratical approach. IRL Press. Washington, D.C.

Hardy, K.J. 1986. Aspects of Microbiology 4, Bacterial Plasmids 2nd ed. American Socieiy for Microbiology. Washington, D.C. 
Harris, J.E., D.M. Evans, M.R. Knox and D.B. Archer. 1986. Genetic approaches with methanogens important in mesophilic digestion. In: Progress in Biotechnology 2, Biology of anaerobic bacteria. pg. 123-137. (eds.) H.C. Dubourguier. Elsevier, New York.

Hintermann, G., H.M. Fischer, R. Crameri and R. Hutter. 1981. Simple procedure for distinquishing $\mathrm{CCC}, \mathrm{OC}$, and $\mathrm{L}$ forms of plasmid DNA by agarose gel electrophoresis. Plasmid. 5: 371-373.

Hippe, H. 1984. Maintenance of methanogenic bacteria. In: Maintenance of microorganisms. A Manual of Laboratory Methods. pg. 69-81. Academic Press, New York.

Holdeman, L.V. and W.E.C. Moore (ed). 1972. Anaerobe laboratory manual. Virginia Polytechnic Institute and State University, Blacksburg.

Holmes, D.S. and H. Quigley. 1981. Anal. Biochem. 114, 193-197.

Hummel, H., M. Jarsch and A. Bock. 1985. Unique antibiotic sensitivity of protein synthesis in atchaebacteria and the possible structural basis. In: Molecular biology of archaebacteria. pg. $370-374$. 
Hummel, H., U. Bar., G. Heller and A. Bock. 1985. Antibiotic sensitivity pattern of in vitro polypeptide synthesis systems from Methanosarcina harkeri and Methanospirillum hungatei. System. Appl. Microhiol. 6, 125-131.

Hungate, R.E. 1950. The anaerobic mesophilic cellulolytic bacteria. Bacteriol. Rev. 14, 1-49.

Jain, M.K., and G. Zeikus. 1987. Methods for the isolation of auxotrophic mutants of Methanobacterium ivanovii and intial characterization of acetate auxotrophs. Appl. Environ. Microbiol. 53(6), 1387-1390.

Jarrell, K.F., J.R. Colvin and G.D. Sprott. 1982. Spontaneous protoplast formation of Methanosarcina barkerii. J. Bacteriol. 149,346-353.

Jarrell, K.F., D. Faguy, A. Herbert M. Kalmokoff. 1991. A General method of isolating high molecular weight DNA from methanogenic Archaea. (not yet pub.)

Jarsch, M., J. Altenbucher and A. Bock. 1983. Physical organization of the genes for ribosomal RNA in Methanococcus vannielii. Mol. Gen. Genet. 189, 41-47. 
Jones, W.J., J.A. Leigh, F. Mayer, C.W. Woese, and R.S. Wolfe. 1983. Merhanococcus jannaschii sp. nov., an extremely thermophilic methanogen from a submarine hydrothermal vent. Arch. Microbiol. 136: 136-261.

Jones, W.J., J.R. Nagle and W.B. Whitmann. 1987. Methanogens and the diversity of archaebacteria. Microbiol. Rev. 51: 135-177.

Jussefie, A., F. Mayer and G. Gottschalk. 1986. Methane formation from methanol and molecular hydrogen by protoplasts of ncw methanogenic isolates and inhibition by dicyclohex:lcarbodimide. Arch. Microbiol. 146, 245-249.

Kandler, O., and H. Hippe. 1977. Lack of peptidoglycan in the cell walls of Methanosarcina barkeri. Arch. Microbiol. 113:57-60.

Kandler, O. and H. Konig. 1978. Chemical composition of the peptidioglycan-free cell walls of methanogenic bacteria. Arch. Microbiol. 118-152.

Kandler, O. 1982. ed. Archaebacteria. Gustav Verlag, Stuttgart.

Kandler, O. and H. Konig. i985. Cell envelopes of archaebacteria. In: The Bacteria, vol. VIll: Archaebacteria.(eds.) C.R. Woese and R.S. Wolfe. pp. 413-458 Academic Press Inc. New York, N.Y. 
Kandler, O. and W. Zillig. 1985. eds. Archaebacteria. Gustav Fischer Verlag. Stuttgart.

Kates, M. 1988. Structure, physical properties, and function of archaebacterial lipids. In: Biological Membranes; Aberrations In Membrane Structure and Function. (eds.) Karnovsky, M.L., A.M. Leaf and L.C. Bolis. pg. 357-384. Alan R. Liss. Inc., New York.

Keltjens, J.T. 1984. Coenzymes of methanogenesis from hydrogen and carbon dioxide. Antonie van Leeuwenhoek J. Microbiol. 50, 383-396.

Kiener, A., C. Holliger and T. Leisinger. 1984. Analogue-resistant and auxotrophic mutants of Methanobacterium thermoautotrophicum. Arch. Microbiol. 139, 87-90.

Kiener, A., T. Rechsteiner and T. Leisinger. 1986. Mutation to pseudomonic acid resistance of Methanobacterium thermoautotrophicum leads to an altered isoleucyl-tRNA synthetase. FEMS Microbiol. Lett. 33, 15-18.

Kiener, A., H. Konig, J. Winter, and T. Leisinger. 1987. Purification and use of Methanobacterium wolfei pseudomurein endopeptidase for lysis of Methanohacterium thermoautotrophicum. J. Bacteriol. 169: 1010-1016. 
Kleinschimdt, A.K. 1968. Monolayer techniques in electron microscopy of nucleic acid molectiles. Methods in Enzymol. 12, 361-377.

Knox, M.R. and J.E. Harris. 1988. Isolation and characterization of mutants of mesophilic methanogenic bacteria resistant to analogues of DNA bases and nucleosides. Arch. Microbiol. 149, 557-560.

Kirsop, B.H. 1990. Methanogenesis. CRC Critical Reviews in Biotechnology. 1(2), 109-159.

Kleinschmidt, A.K. (1986). Monolayer techniques in electron microscopy of nucleic acids. Methods Enzymol. 12: 361-377.

Konheiser, U., G. Pasti, C. Bollsch weiler and A. Klein. 1984. Physical mapping of genes coding for two subunits of methyl CoM reductase component $\mathrm{C}$ of Methanococcus voltae. Mol. Gen. Genet. 198, 146-152.

Konig, H. and K.O. Stetter. 1986. Studies on archaebacterial i layers. System. Appl. Microbiol. 7, 300-309.

Konig, H. 1988. Archaebacterial cell envelopes. Can. J. Microbiol. 34: 395-406. 
Konig, H. 1988. Archaeobacteria. In: Biotechnology, vol. 66. Special microbial processes. eds. H. J. Rehn and G. Reed. Cte Publishers, New York, New York. pg.697728.

Kreisl, P., and O. Kandler. 1986. Chemical structure of the cell wall polymer of Methanosarcina. Syst. Appl. Microbiol. 7:293-299.

Kushwaha, S.C. M. Kates, G.D. Sprott, and I.C.P. Smith. 1981. Novel polar lipids from the methanogen Methanospirillum hungatei GP1. Biochim. Biophys. Acta. 664, 156-173.

Ladapo, J. and W.B. Whitman. 1990. Method for the isolation of auxotrophs in the methanogenic archaebacteria: role of acetyl-CoA pathway of auxotrophic $\mathrm{CO}_{2}$ fixation in Methanococcus maripaludis. Proc. Natl. Acad. Sci. U.S.A. 87, 5598-5602.

Langworthy, T.A. 1985. Lipids of Archaebacteria. In: The Bacteria, Vol. VIII, Archaebacteria. (eds.) C.R. Woese and R.S. Wolfe. 459-498. Academic Press Inc. New York, N.Y.

Maniatis, T., E.F. Fritsch and J. Sambrook. 1982, 1989. Molecular Cloning. Cold Spring Harbor Laboratory, Cold Spring Harbor, New York. 
Mavarech, M. and R. Werczberger. 1985. Genetics transfer in Halobacterium volcanii. J. Bacteriol. 162, 461-462.

Marmur, J. 1961. A procedure for the isolation of deoxyribonucleic acid from microorganisms. J.Mol. Biol. 3:208-218.

Martin, J.H. and D.C. Savage. 1988. Degradation of DNA in cells and extracts of the obligately anaerobic bacterium Roseburia cericola upon exposure to air. Appl. Env. Microbiol. 54, 1619-1621.

Meakin, S.A., J.H.E. Nash, W.D. Murray, K.J. Kennedy and G.D. Sprott. 1991 . A generally applicable technique for the extraction of restrictable DNA from methanogenic bacteria. J. Microbiol. Methods. 14, 119-126.

Meille, L. A. Kiener and T. Leisinger. 1983. A plasmid in the Archaebacterium Methanobacterium thermoautotrophicum. Mol. Gen. Genet. 191: 480-484.

Meille, L. and J.N. Reeve. 1985. Potential shuttle vectors based on the methanogen plasmid pME2001. Biotechnology, pg. 69-72.

Meille, L. P. Abendschein and T. Leisinger. 1990. Transduction in the archaebacterium Methanobacterium thermoautotrophicum Marburg. 172(6), 3507-3508. 
Micheletti, P.A., K.A. Sment and J. Konisky. 1991. Isolation of a coenzyme-M auxotrophic mutant and transformation by electroporation Methanocicciks volrae. J. Bacteriol.

Mitchell, R.M., L.A. Loeblich, L.C. Klotz and A.R. Loblich. 1979. DNA organization of Methanobacterium thermoautotrophicum. Science. 204, 1082-1084.

Nolling, J., M. Frijlink and W.M. De Vos. 1991. Isolation and characterization of plasmids from different strains of Methanobacterium thermoformicicum. J. Gen. Microbiol., 137, 1981-1986.

Myers, J.A., D. Sanchez, L.P. Elwell and S. Falkow. 1976. Simple agarose gel electrophoretic method for the identification and characterization of plasmid deoxyribonucleic acid. J. Bacteriol. 127(3), 1529-1537.

Nuber, E. and H. Konig. 1986. S layer studies on three species of Merhanociccus living at different temperatures. Can. J. Microbiol. 33, 256-261.

Nuber, E. and H. Konig. 1987. Cell envelope studies on three species of Methanococcus living at different temperatures. Can. J. Microbiol. 33: 256-261. 
Patel, G.B. G.D. Sprott, R.W. Humphrey, and T.J. Reveridge. 1986. Comparative analyses of the sheath structures of Methanothrix concilli GP6 and Methanospirillium hungatei strains GP1 and JF1. Can. J. Microbiol. 32: 623-631.

Patel G.B., and G.D. Sprott. 1990. Methanosaeta concilii gen.nov., sp. nov. ("Methanothrix concilli") and Methanosaeta thermoacetophila nom. rev., comb. nov. Int. J. Syst. Bacteriol. 40: 79-82.

Patel, G.B., G.D. Sprott, and J.E. Fein. 1990. Isolation and characterization of Methanobacterium espanolae sp. nov., a mesophilic, moderately acidophilic methanogen. Int. J. Syst. Bacteriol. 40: 12-18.

Possot, O., P. Gernhardt, A. Klein and L. Sibold. 1988. Analysis of drug resistance in the archaebacterium Methanococcus voltae with respect to potential use in genetic engineering. Appl. Environ. Microbiol. 54(3), 734-740.

Postgate, J.R. 1969. Methane as a minor product of pyruvate metabolism by sulphatereducing and other bacteria. J. Gen. Microbiol. 57:293-302.

Rechsteiner, T., A. Kiener and T. Leisinger. 1986. Mutants of Methanobacterium themoautotrophicum. Syst. Appl. Microbiol. 7, 1-4. 
Reeve, J.N., N.J. Trun and P.T. Hamilton. 1982. Beginning genetics with methanogens. In: Genetic Engineering of Microorganisms for Chemicals. (eds.) A. Hollaender, R.D. DeMoss, S. Kaplan, J. Konisky, D. Savage and R.S. Wolfe. pg. 233244. Plenum Publishing Corp., New York.

Reeve, J.N., P.T. Hamilton, G.S. Beckler, C.J. Morris and C.H. Clarke. 1986. Structure of methanogen genes. System. Appl. Microbiol. 7, 5-12.

Reeve, J.N. 1988. Molecular biology of methanogens and methanogenesis. In: Genetics and molecular biology of industrial microorganisms.

Rosenshine, I., R. Tchelet and M. Mevarech. 1989. The mechanism of DNA transfer in the mating system of an archaebacterium. Science. 245, 1387-1389.

Roustan, J.L., J.P. Touzel, G. Prensier H.C. Dubourguier and G. Albagnac. 1986. Evidence for a lytic bacteriophage for Methanothrix sp. In; Biology of Anaerobic bacteria. eds. H.C. Dubourguier et. al., Elsevier Science Publishers, The Netherlands.

Rouviere, P. and R.S. Wolfe. 1988. Novel biochemistry of methanogenesis. J. Biol. Chem. 263, 7913-7916. 
Sambrook, J., E.F. Fritsch and T. Maniatis. 1989. Molecular Cloning: A Laboratory Manual. Second edition. Cold Spring Harbor Laboratory Press. Cold Spring harbor, New York.

Sandbeck, K.A. and J.A. Leigh. 1991. Recovery of an integration shuttle vector from tandem repeats in Methanococcus maripaludis. Appl. and Environ. Microbiol. 57(9), 2762-2763.

Santoro, N. and J. Konisky. 1987. Characterization of bromoethanesulfonate resistant mutants of Methanococcus voltae: evidence of a coenzyme $M$ transport system. J. Bacteriol. 169, 660-665.

Schaffer, H.E. and R.R. Sederoff. 1981. Improved estimation of DNA fragment lengths from agarose gels. Anal. Biochem. 115, 113-122.

Schauer, N.L. and J.G. Ferry. 1980. Metabolism of formate in Methanobacterium formicicum. J. Bacteriol. 142, 800-807.

Schauer, N.L. and J.G. Ferry. 1986. Composition of the coenzyme $F_{420}$-dependent formate dehydrogenase from Methanobacterium formicicum. J. Bacteriol. 165, 405-411. 
Serwer, P. 1990. Sieving by agarose gels and its use during pulsed-field electrophoresis. Biotech and Genetic Engineering Reviews. Vol.8, pg. 319-343.

Shaw, P.J., G.J. Hills, J.A. Henwood, J.E. Harris and D.A. Archer. 1985. Three dimensional architecture of the cell sheath and septa of Methanospirillum hungatei J. Bacteriol. 161, 750-757.

Shuber, A.P., E.C. Orr, M.A. Recnay, P.F. Schendel, H.D. May, L. Schauer and J.G. Ferry. 1986. Cloning, expression and nucleotide sequence of the formate mutants of Methanobacterium formicicum. J. Biol. Chem. 261, 12942-12947.

Sleytr, U.B. and M. Sara. 1986. Ultrafiltration membranes with uniform pores from crystalline bacterial cell envelope layers. Appl. Microbiol. Biotech. 25: 83-90.

Sleytr, U.B., P. Messner, M. Sara and D. Pum. 1986. Crystalline envelope layers in archaebacteria. System. Appl. Microbiol. 7, 310-313.

Smucker, R.A. and R.M. PTister. 1975. Liquid nitrogen cryo- impacting: a new concept for cell disruption. Appl. Microbiol. 30, 445-449. 
Sowers, K.R. S.F. Baron and J.G. Ferry. 1984. Methanosarcina acetivorans sp. nov., an acetotrophic methane producing bacterium isolated from marine sediments. Appl. Environ. Microbiol. 47, 971-978.

Sowers, K.R. and R.P. Gunsalus. 1988. Adaptation for growth at various saline concentrations by the archaebacterium Methanosarcina thermophila. J. Bacteriol. 170, 998-1002.

Sprott, G.D., J.R. Colvin and R.C. McKellar. 1979. Spheroplasts of Merhanospirillum hungatei formed upon treatment with dithiothreitol. Can. J. Microbiol. $32,847-854$.

Sprott, G.D. and R.C. McKeller. 1980. Composition and properties of the cell wall of Methanospirillium hungatei. Can. J. Microbiol. 26, 115-118.

Sprott, G.D., T.J. Beveridge, G.B. Patel, and G. Ferrante. 1986. Sheath disassembly in Methanospirillum hungatei strain GP1. Can. J. Microbiol 32: 847-854.

Sprott, G.D., I. Ekiel, and C. Dicaire. 1990. Novel, acid labile, hydroxydiether lipid cores in methanogenic bacteria. J. Biol. Chem. 265: 13735-13740. 
Sprott, G.D., C.G. Choquet, G.B. Patel and I. Ekeil. 1992. Formation of stable liposomes from lipid extracts of archaeobacteria. U.K. Informal Patent Application.

Stetter, K.O., M. Thomm, J. Winter, G. Wildgrubber, H. Huber, W. Zillig, D. van Ecovic, H. Konig, P. Palm and S. Wunderl. 1981. Methanothermus fervidus, sp. nov., a novel extremely thermophilic methanogen isolated from an Icelandic hot spring. Zentralbl. Bakteriol. Parasitenkd. Infectionskr. Hyg. Abt. I. Orig., C2, 166-178.

Stewart, M., T.J. Beveridge and G.D. Sprott. 1985. Crystaline order to high resolution in the sheath of Merhanospirillum hungatei: a cross-beta structure. J. Mol. Biol. 183, 509-515.

Taylor, C.D. and R.S. Wolfe. 1974. Structure and methylation of coenzyme M (HS$\mathrm{CH}_{2}-\mathrm{SO}_{3}$.). J. Biol. Chem. 249, 4879-4885.

Thauer, R.K. 1990. Energy metabolism of methanogenic bacteria. Biochim. Biophys. Acta. 1018, 256-259.

Thomm, M., J. Altenbuchner and K.O. Stetter. 1983. Evidence for a plasmid in a methanogenic bacterium. J. Bacteriol. 153(2): 1060-1062. 
Thomm, M. and G. Wich. 1988. An archaebacterial promoter element for stable RNA genes with homology to the TATA box of higher eukaryotes. Nucleic Acids Res. 16: $151-163$.

Thomm, M., G. Wich, J.W. Brown, G. Frey, B.A. Sherf and G.S. Beckler. 1989. An archaebacterial promoter sequence assigned by RNA polymerase binding experiments. Can. J. Microbiol. 35, 30-35.

Weil, C.F., D.S. Cram, B.A. Sherf, and J.N. Reeve. 1988. Structure and comparative analysis of the genes encoding component $C$ of methyl coenzyme $M$ reductase in the extremely thermophilic archaebacterium. Methanothermus fervidus. I. Bacteriol. 170: 4718-4726.

Weil, C.F., B.A. Sherf and J.N. Reeve. 1989. A comparison of the methyl reductase genes and gene products. Can. J. Microbiol. 35, 101-108.

Whitman, W.B. 1985. Methanogenic Bacteria. In: Woese, C.R., Wolfe R.S. (eds.), The Bacteria, Vol.8: Archaebacteria. pg. 3-65, Academic Press, New York, N.Y.

Wilharm, T., M. Thomm and K.O. Stetter. 1986. Genetic analysis of plasmid pMP1 from Methanolobus vulcani. System. and Appl. Microbiol. 7, 401. 
Williams, R.T. and R.L. Crawford. 1985. Methanogenic bacteria, including an acid tolerant strain, from peatlands. Appl. Env. Microbiol. 50, 1542-1544.

Woese, C.R. 1987. Bacterial evolution. Microbiol. Rev. 51: 221-271.

Woese, C.R., O. Kandler and M.L. Wheels. 1990. Towards a natural system of organisms: Proposal for the Archaea, Bacteria and Eucarya. Proc. Natl. Acad. Sci. 87: 4576-4579.

Woese, C.R. and G.J. Olsen. 1986. Archaebacterial Phylogeny: Perspectives on the Urkingdoms. System. Appl. Microbiol. 7, 161-177.

Woese, C.R. and R.S. Wolfe. 1985. (eds.): The Bacteria, Vol. VIII: Archacbacteria. Academic Press Inc. New York, N.Y.

Wolfe, R.S. 1971. Microbial formation of methane. Adv. Microb. Physiol. 6, 107146.

Wolfe, R.S. 1979. Methanogens: a surprising microbial group. Antonic van Leeuwenhook. 45, 353-364. 
Wolfe, R.S. 1985. Unusuai coenzymes from methanogens. Trends Biochem. Sci. 10, 396-399.

Wood, A.G., A.H. Redburg, D.R. Cue, W.B. Whitman snd J. Konisky. 1983. Complementation of $\arg G$ and hisA mutations of Escherichia coli by DNA cloned from the archaebacterium Methanococcus voltae. J. Bacteriol. 156, 19-20.

Wood, A.G., W.B. Whitman and J. Konisky. 1985. A newly isolated methanogen harbors a small cryptic plasmid. Arch. Microbiol. 142, 256-261.

Worrel, V.E., D.P. Nagle, D. McCarthy, and A. Eisenbraun. 1988. Genetic transformation system in the archaebacterum Methanobacterium thermoautotrophicum Marburg. J. Bacteriol. 170: 653-656.

Zhao, H., A.G. Wnod, I'. Widdel and M. P. Bryant. 1988. An extremely thermophilic Methanococcus from a deep sea hydrothermal vent and its plasmid. Arch. Microbiol. 150: 178-183.

Zillig. W.P., W.D. Reiter, F. Gropp, G. Puhler and H.P. Klenk. 1988. Comparative evaluation of gene expression in archaebacteria. Eur. J. Biochem. 173, 474482. 

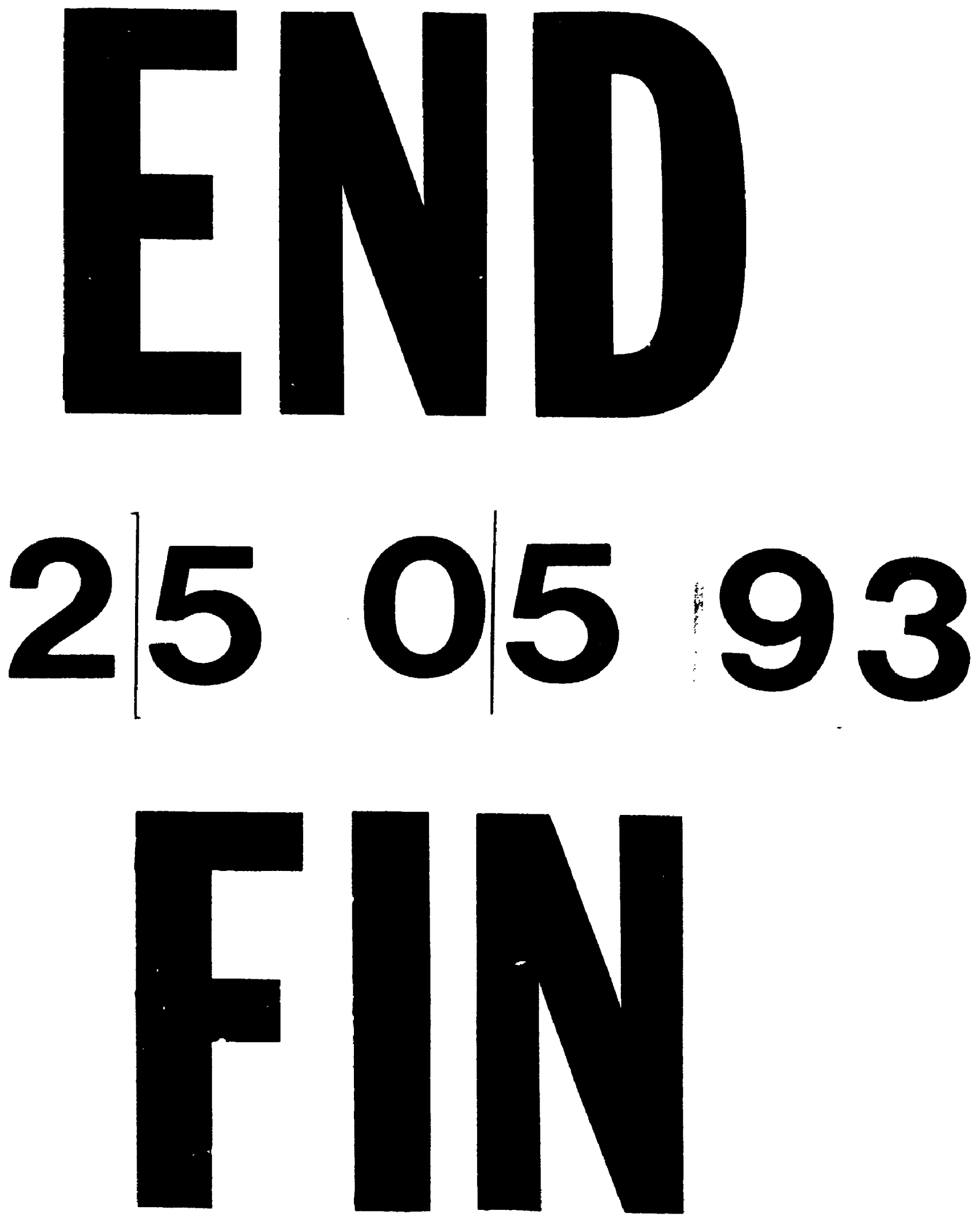